\title{
Analysis of ether-à-go-go potassium channel (Eag1) splice variants in melanoma cells
}

\author{
Dissertation \\ zur Erlangung des Doktorgrades \\ der Mathematisch-Naturwissenchaftlichen Fakultäten \\ der Georg-August-Universität zu Göttingen
}

vorgelegt von

Fernanda Ramos Gomes

aus Petrópolis-Rio de Janeiro, Brasilien

Göttingen, 2010 
D7

Referent: Prof. Dr. Jörg Stülke

Korreferent: Prof. Dr. Stefanie Pöggeler

Tag der mündlichen Prüfung: 29/04/2010 
To my mom............. 


\section{Acknowledgments/Agradecimentos}

To Prof. Walter Stühmer, for welcoming me in his lab, for all trust, help, support and encouragement. Thank you for everything.

El Dr. Luis Pardo por la orientación en todo, incluso cuando em los momentos dificiles. Gracias por la paciencia, el compañerismo y la amistad. Dra. Araceli Sánchez, le agradezco todos los consejos y la ayuda con los experimentos y por supuesto todas nuestras conversaciones.

Everyone in the MBNS Lab., thank you for all the help, support and for always providing me a wonderful working place! In particular thanks to Victor Dias, Ute, Kerstin, Kerstin D., Uschi, Alonso Barrantes, Franziska, Márcio, Éva L., Roser.

A minha família:

Minha mãe querida que infelizmente não esta aqui pra poder comigo mais este pequeno degrau subir. Muito obrigada por tudo, por ter confiado em mim, por ter estado comigo em todos os momentos até eu chegar a fazer doutorado na Alemanha, quem pensou nisso não é?! Tenho certeza que você esta muito feliz com isso e sinto muito por não ter estado com você em momentos que foram tão marcantes. Não te esqueço nunca e te amo pra sempre!

Meu pai que sempre esteve ao meu lado, sempre me apoiando e confiando em minhas decisões, pai, foi muito importante isto e ainda é muito importante toda a confiança que eu sinto de você! Muito obrigada por ter me proporcionado uma família tão linda!

Minha irmã que eu tenho certeza, apesar de sermos muito diferentes, esta sempre feliz quando eu estou feliz! Eu também estarei sempre feliz quando te ver feliz! Te amo! Ao Henry porque eu sempre vou me lembrar de você escrevendo a tese de mestrado comigo, agora é a de doutorado meu amor! Sinto muitas saudades de você!

E a minha família em geral, minha avó Julieta querida que também deposita em mim muita confiança, amor e carinho! Vó a senhora é meu orgulho também, completou o segundo grau com mais de 70 anos, muito linda ela gente! Todas as minhas tias, primos e tios queridos, tia Preta, tia Aparecida, tia Zizinha, tia Beth, tio Pedrinho e Alcione, tia Dalva, Elizeth, tio Chico que sempre se lembraram de mim aqui, que sentimos saudades infinitas uma da outra, conversas que rimos e choramos pelo telefone! Obrigada pela forca em todos os momentos! 
Aos meus amigos de longe e de perto, novos e velhos. Marimar e a família dela, uma amizade linda, que como a vida tem pedras, mas que com muita maturidade a amor uma pela outra removemos e removeremos sempre que elas aparecerem. Fernanda Queiroz e a família dela, família nova e família no Brasil, Fê muito obrigada por tudo mesmo, não da pra escrever todas as coisas que passamos juntas aqui, mas foram intensas e obrigada por estar junto quando precisei. Vanessa, querida amiga que com certeza vai ficar pra sempre, muito obrigada pela confiança e amizade, por momentos que nunca terei palavras para agradecer, saiba que você vai estar comigo pra sempre. A todos vocês meu muito obrigada, Elke e Janaína (saudades de vocês), Aline Fofano, Crystian, Nívea, Marianna, Flávia, Nádia, Carlinha, Play, Simone, Vanessa, Pedro.........amigos que mesmo de longe fazem muita falta!

Minha querida Ci! Cilene muito obrigada por tudo! Tudo mesmo! Te adoro!

Und Christoph, du bist das schönste Geschenk dass Deutschland gegeben mir hat! Danke dass du an meiner Seite bist, mich unterstützt und für deine Geduld auch wenn ich meine schon verloren habe.

E por último eu quero agradecer a Deus, por me dar saúde, forca e coragem pra seguir em frente todos os dias e se mostrar sempre presente, até mesmo quando eu mais fraquejo!

To all of you, thank you! 


\section{Contents}

1 Introduction 1

1.1 Ion channels 1

1.2 Ion channels and cancer 4

$\begin{array}{lll}1.3 & \text { Eag family of ion channels } & 7\end{array}$

$\begin{array}{lll}1.4 & \text { Eagl and cancer } & 12\end{array}$

1.5 Splice variants 14

1.5.1 Alternative pre-mRNA splicing 15

$\begin{array}{ll}\text { 1.5.2 Alternative splice and cancer } & 18\end{array}$

$\begin{array}{ll}1.6 \text { Melanomas } & 20\end{array}$

1.6.1 The melanoma cell line IGR39 23

2 Aims $\quad 26$

$3 \quad$ Materials \& Methods

3.1 Cell culture 27

$\begin{array}{lll}3.2 & \text { Drugs } & 28\end{array}$

3.3 Molecular Biology 28

3.3.1 Total RNA isolation and cDNA synthesis 28

3.3.2 Endonuclease digestion 31

3.3.3 Plasmids, constructs and cRNA preparation 32

$\begin{array}{lll}3.4 & \text { Confocal Microscopy } & 33\end{array}$

$\begin{array}{lll}3.5 & \text { Real-time PCR } & 34\end{array}$

$\begin{array}{lll}3.6 & \text { PCR } & 34\end{array}$

3.7 siRNA transfections $\quad 35$

$\begin{array}{lll}3.8 & \text { Xenopus oocytes preparation } & 37\end{array}$

3.9 Protein extraction, separation and western blot 37

3.10 Electrophysiology 39

$\begin{array}{ll}3.10 .1 \text { Patch-Clamp } & 39\end{array}$

3.10.2 Two-electrode voltage-clamp $\quad 40$

3.11 Northern-blot 41

$\begin{array}{ll}3.12 \text { Statistical analysis } & 44\end{array}$ 


\section{Results}

4.1 Functional Characterization of Eag1 in Melanoma Cells 45

4.1.1 Both IPC298 and IGR39 express Eag1 RNA and protein 45

4.1.2 Ion currents in melanoma cell lines 49

4.1.3 Pharmacology of currents measured in melanoma cell lines 52

4.1.4 siRNA reduces Eag1 mRNA and current in melanoma cell lines

4.2 Detection of new hEag1 Splice Variants in Melanoma Cell Lines $\quad 60$

4.2.1 Detection of splice variants by nested-PCR 60

4.2.2 Expression of splice variants in Xenopus leavis oocytes 64

4.2.3 Characterization of E65 and E70 effects on Eag1 current expressed in Xenopus leavis oocytes 65

4.2.4 Maturation induced by E65 in Xenous leavis oocytes 69

$\begin{array}{ll}\text { 4.2.5 Northern-blot analysis of the variant mRNA } & 76\end{array}$

$\begin{array}{lll}4.3 & \text { Subcellular localization of E65 splice variant } & 78\end{array}$

4.4 Other experiments $\quad 80$

4.4.1 Expression of E65 in Neural Stem Cells 80

4.4.2 Identification of low-abundance alternatively spliced mRNA 83

5 Discussion

85

5.1 Eag1 in melanoma cell lines $\quad 85$

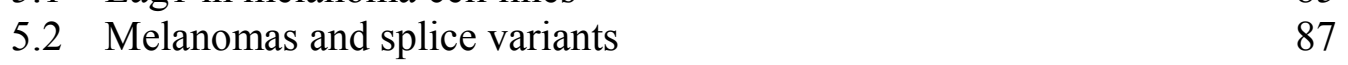

5.3 Xenopus oocytes maturation induced by E65 89

$\begin{array}{lr}\text { Bibliography } & 92\end{array}$ 


\section{List of Figures}

1.1 Transporters and channels proteins 2

$\begin{array}{ll}1.2 & \text { Putative structure of the Eag1 channel monomer } \\ 10\end{array}$

$\begin{array}{lll}1.3 & \text { Schematic view of constitutive and alternative splicing } & 17\end{array}$

1.4 Annual incidence of new cases of malignant tumors in USA 20

1.5 Astemizole reduces proliferation in melanoma cell lines 23

1.6 RT-PCR for Eag1 in melanoma cell lines 24

1.7 Eag1 immunostaining in melanoma cell lines 25

3.1 total RNA extraction 29

3.2 mRNA extraction 31

3.3 Northern-blot membrane transference 42

4.1 hEag1 expression by RT-PCR 47

4.2 Immunoprecipitation of Eag1 in melanoma cell lines 48

4.3 Currents expressed by the melanoma cell lines in
presence of $1 \mathrm{mM} \mathrm{Mg}^{+2}$

4.4 Activation kinetics of Eag1 channels in melanoma cell lines 51

4.5 Sensitivity of IPC298 and IGR39 melanoma currents to Imipramine 53

4.6 Sensitivity of IPC298 and IGR39 melanoma currents
to Astemizole

4.7 Reduction of Eag1 message in melanoma cells by siRNA 56

4.8 Reduction on Eag1 protein level in melanoma cells by siRNA 57

4.9 Reduction on Eag1 current in melanoma cells by siRNA 58

4.10 Detection of splice variants by Nested-PCR 61

4.11 Representative schemes showing the two melanomas splice variants

4.12 Sequence alignment of amino acids sequences of the Eag1 WT with the two alternative spliced forms E70 and E65 63

4.13 Expression of splice variants E70 and E65 protein in Xenopus oocytes

64

4.14 Functional characterization of E65 and E70 expressed together with Eag1 in Xenopus oocytes 66

4.15 Activation kinetics of Eag1 co-injected with E65 and E70 in Xenopus oocytes 
4.16 Interaction with E65 is specific for Eag1 channels

4.17 Comparison between Eag WT vs Eag+E65 currents in non-mature and mature Xenopus oocytes

4.18 Maturation induced by progesterone in injected Xenopus oocytes

4.19 Maturation incudeced by E65 in Xenopus oocytes

4.20 E65-induced maturation in Xenopus oocytes is cyclin B2 independent

4.21 Northern-blot analysis of variant $\mathrm{mRN}$ expression in human cells

4.22 Subcellular localization of HEK293-Eag1 transfected with E65Venus

4.23 Confocal microscopy of Eag1 in rNSCs

81

4.24 rNSCs splice variants detection by Nested-PCR

4.25 Identification of Eag1 gene transcripts that are expressed differentially in melanoma cells and NSC via exon exclusive RT-PCR 


\section{List of Tables}

1 Deoxyoligonucleotides used in cleavage of cited exons 32

2 Primer sequences and their respective sizes and targets 46

3 Number of oocytes that exhibited GVBD 73

4 Bands identified via exon exclusive PCR 88 


\section{Abbreviations}

\begin{tabular}{|c|c|}
\hline $\mathrm{K}^{+}$ & potassium ions \\
\hline $\mathrm{Na}^{+}$ & sodium íons \\
\hline $\mathrm{Ca}^{+2}$ & calcium íons \\
\hline $\mathrm{Cl}^{-}$ & chlorine íons \\
\hline $\mathrm{Mg}^{+2}$ & magnesium íons \\
\hline ATP & adenosine triphosphate \\
\hline IGR1 & human melanoma cell line \\
\hline $\mathrm{MCF}-7$ & human breast cancer \\
\hline IPC298 & human melanoma cell line \\
\hline IGR39 & human melanoma cell line \\
\hline Eag & ether-à-go-go potassium channel \\
\hline hERG & human eag-related gene \\
\hline hELK & human eag-like \\
\hline cAMP & cyclic adenosine monophosphate \\
\hline TEA & tetraethylammonium \\
\hline 4-AP & 4-aminopyridine \\
\hline E4031 & ERG block channel \\
\hline $\mathrm{K}_{\mathrm{v}}$ & voltage-gated potassium channel \\
\hline $\mathrm{K}_{\mathrm{Ca}}$ & calcium-gated potassium channel \\
\hline $\mathrm{CHO}$ & epithelial cell derived from the ovary of the Chinese hamster \\
\hline NIH3T3 & mouse embryonic fibroblast cell line \\
\hline HEK293 & human Embryonic Kidney 293 cells \\
\hline SCID & severe combined immunodeficiency disease \\
\hline MPF & mitosis-promoting factor \\
\hline DNA & deoxyribonucleic acid \\
\hline RNA & ribonucleic acid \\
\hline siRNA & small interfering RNA \\
\hline mRNA & messenger RNA \\
\hline cRNA & RNA derived from cDNA through standard RNA synthesis \\
\hline $\mathrm{AS}$ & alternative splicing \\
\hline NFR & normal frog ringer \\
\hline Eag WT & Eag wild type \\
\hline GVBD & germinal vesicle breakdown \\
\hline PCR & polymerase chain reaction \\
\hline $\mathrm{IC}_{50}$ & inhibitory concentration maximum \\
\hline
\end{tabular}




\section{Abstract}

The human ether-à-go-go potassium channel (hEag1) can be detected in adult brain and in both, tumor cell lines and primary tumors. The physiological function of this channel in the brain still remains to be elucidated. The presence of hEag1 in tumors has been linked to an increase in proliferation. Published reports claimed that the IGR39 melanoma cell line is negative for hEag1, what allowed this cell to be used as negative control. We observed that IGR39 cells shows positive amplification for hEag1, at mRNA level, and a protein with compatible molecular weight and reactivity for hEag1 antibody, was detected in western-blot experiments. The biophysical properties of the current registered in IGR39 presents a different kinetics, but it is still sensitive to blocking by drugs and siRNA specific for hEag1. Using molecular biology techniques, we found the expression of two new splice variants, E65 and E70, in two melanoma cell lines (IPC298 and IGR39) and in neural stem cells. The two splice variants have no transmembrane domains and can not form a functional membrane-bound channel. A characterization of the new splice variants was done in Xenopus leavis oocytes, to verify the interaction of the splice variants with the full-length hEag1 (fl-hEag1). Electrophysiological measurements of the oocytes, co-injected with the splice variant E65 and the fl-hEag1, showed a rectified current with diminished amplitude. Moreover, the co-injection of E65 and fl-hEag1 enables these oocytes to mature, which was the same outcome of the treatment of oocytes with progesterone. Based in these results, we conclude that IGR39 cell line express Eag1 channels and the splice variants found in these melanoma cells, could be either interacting with the full-length Eag1 or playing a role in the intracellular signaling. 


\section{Introduction}

\subsection{Ion Channels}

"Ion channels are macromolecular pores in cell membranes. When they evolved and what play they have played in the earliest forms of life we don't know, but today ionic channels are most obvious as the fundamental excitable elements in the membranes. As sensitive but potent amplifiers, these ionic channels detect the sounds

of chamber music, guide the artist's paint-brush, or generate the violent electric discharges of the electric eel or the electric ray. They tell the Paramecium to swim backward after a gentle collision, and they propagate the leaf-closing response of the Mimosa plant (Hille, 2001).”

The emergence of the cell membrane was essential for the development of the cell because it formed a barrier that allowed the cell to keep all vital components. However, cells have had to evolve ways of transferring specific water-soluble molecules and ions across their membranes in order to ingest essential nutrients, excrete metabolic waste products, and regulate intracellular ion concentrations. Cells use specialized transmembrane proteins to transport inorganic ions and small water molecules. Cells can also transfer macromolecules through a more complex mechanism 
(Hille, 2001; Alberts et al., 2008).

Transporters and channels are the two major classes of membrane transport proteins. Transporters (also called carriers) bind the specific solute to be transported and undergo a series of conformational changes to transfer the bound solute across the membrane. Channels, in contrast, interact with the solute to be transported much more weakly. They form aqueous pores that extend across the lipid bilayer; when open, these pores allow specific solutes (usually inorganic ions of appropriate size and charge) to pass through them and thereby cross the membrane (Figure 1.1). Transmembrane movement of small molecules mediated by transporters can be either active or passive, whereas that mediated by channels is always passive (Alberts et al., 2008).

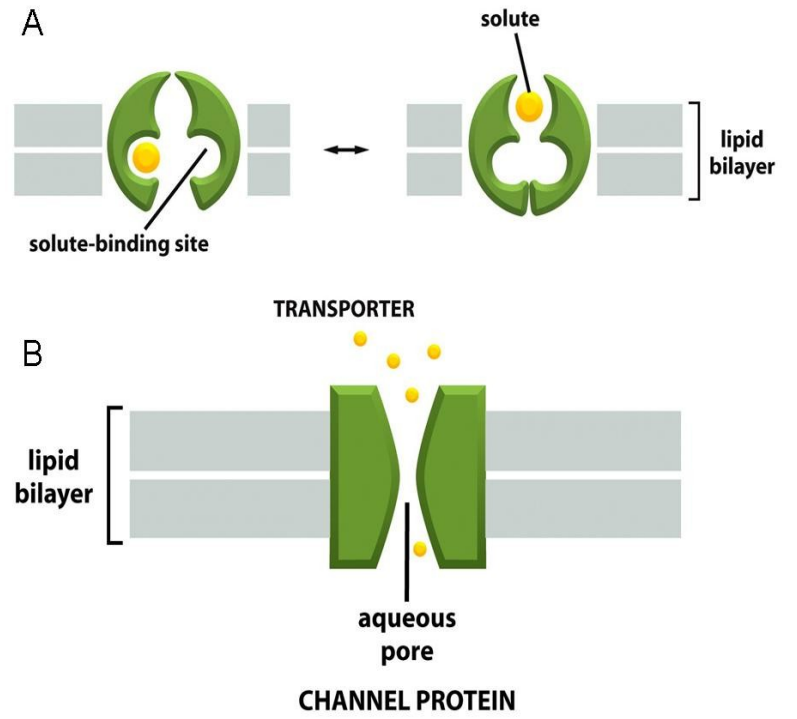

Figure 1.1 Transporters and channels proteins. (A) A transporter alternates between two conformations, so that the solute-binding site is sequentially accessible on one side of the bilayer and then on the other. (B) In contrast, a channel protein forms a water-filled pore across the bilayer through which specific solutes can be diffuse (Adapted from Alberts et al., 2008). 
Two important properties distinguish ion channels from simple aqueous pores. First, they show ion selectivity, permitting some inorganic ions to pass, but not others. Only ions with appropriate size and charge can pass. The second important distinction between ion channels and simple aqueous pores is that ion channels are not continuously open. Instead, they are gated, which allows them to open briefly and then close again. Moreover, with prolonged (chemical or electrical) stimulation, most channels go into a closed "desensitized" or "inactivated" state.

The channels are gated and usually open transiently in response to a specific perturbation in the membrane, such as a change in membrane potential (voltage-gated channels) or the binding of ligands (ligand-gated channels) (Alberts et al., 2008).

Ion channels play an important role in action potentials generation and propagation in excitable cells, such as neurons and muscle fibers. In non excitable cells, ion channels mediate cellular functions involving intracellular biochemical responses, rather than rapid electrical signaling. The presence of channels is required for several basic functions, such as activation and secretion of lymphokines, mitogenesis, the regulation of cell volume and the mechanisms of resistance to chemotherapeutic agents (Bértran et al., 1995).

A membrane potential arises when a concentration gradient of ions across a membrane with a selective permeability for these ions is established. This causes a slight difference in the electrical charge on the two sides of the membrane, due to a slight excess of positive ions over negative ones on one side and a slight deficit on the other. Such charge differences can result both from active electrogenic pumping and from passive ion diffusion across the membrane. In typical animal cells, passive ion movements make the largest contribution to the electrical potential across the plasma 
membrane (Alberts et al., 2008). These ionic concentrations in intracellular and extracellular compartments together with the selective membrane permeability establish the membrane potential (Hille, 2001).

At rest, this balancing role is performed largely by potassium $\left(\mathrm{K}^{+}\right)$ions, which are actively pumped into the cell by the $\mathrm{Na}^{+}-\mathrm{K}^{+}$pump and can also move freely in or out through the $\mathrm{K}^{+}$leak channels in the plasma membrane. Because of the presence of these channels, $\mathrm{K}^{+}$reaches almost equilibrium, where an electrical force exerted by an excess negative charges attracting $\mathrm{K}^{+}$into the cell balance the tendency of $\mathrm{K}^{+}$to leak along its concentration gradient. The membrane potential is the manifestation of this electrical force (Alberts et al., 2008).

\subsection{Ion Channels and Cancer}

Membrane ion channels are essential for cell proliferation and appear to have a role in the development of cancer. Ion channels belong to the fundamental inventory of any living cell and are required for cell proliferation (Kunzelmann, 2005). Electrophysiological studies show that tumor cells are depolarized when compared with normal tissue cells, and that has been proposed as a necessary condition for cells that have a limitless proliferation (Marino et al., 1994). Inhibition of $\mathrm{K}^{+}$channel expression or blockade by selective inhibitors reduces cell proliferation (Wang, 2004).

Among ion channels expressed in excitable or non-excitable cells, the $\mathrm{K}^{+}$ channels are the most diverse in structure and function. Although the gating, structure and permeability mechanism of the $\mathrm{K}^{+}$channel have been partly clarified (Bezanilla, 2005; Jiang et al, 2003a; Jiang et al, 2003b), there are still many open questions about 
their location and role in biological processes such as cell proliferation and survival of tumor cells.

More than 80 genes encoding for potassium channels have been identified. The different $\mathrm{K}^{+}$channels have distinct electrophysiological properties and are gated by specific tissue transcriptional control or through the action of specific effectors, as much diverse as electrical potential, calcium levels $\left(\mathrm{Ca}^{+2}\right)$ or ATP cytoplasmic, kinases, phosphatases, neurotransmitters or hormones.

Some of these ion channels are essential for cell proliferation control and for protein synthesis during the cell growth. There is an established association between lymphocyte voltage-gated $\mathrm{K}^{+}$channels (Chandy et al., 1984; DeCoursey et al., 1984, Amigorena et al., 1990a; Amigorena et al., 1990b) and mitogenesis during the immune response. $\mathrm{K}^{+}$channel activation is associated with $\mathrm{Ca}^{+2}$-induced differentiation in keratinocytes (Mauro et al., 1997) and modulation of potassium channels on the melanoma cell line IGR1 influences cell proliferation and the incorporation of $\left[{ }^{3} \mathrm{H}\right]$ thymidine into these cells (Nilius and Wohlrab, 1992).

Since tumor cells are highly proliferative, is not surprising that many $\mathrm{K}^{+}$ channels are associated with cancer. There is currently no clear understanding on how these $\mathrm{K}^{+}$channels actually promote proliferation. In addition, not only $\mathrm{K}^{+}$channels have a role in proliferation but also other ion channels selective for $\mathrm{Cl}^{-}, \mathrm{Ca}^{+2}$, and nonselective cation channels. Some ion channels with a clear relationship to particular tumor types are:

$1-\underline{\mathrm{K}^{+} \text {Channels }}$ : leukemia cell lines (PLB-985, K562, UT7, HEL and HL-60) and primary acute myeloid leukemia, (breast cancer (MCF-7), rat glioma (C6), colon 
adenocarcinoma, prostate adenocarcinoma (LNCap and PC-3), and rat (Mat-LyLu and AT-2), liver (Hep 2, HuH-7 and HFL), myeloma (RPMI-8226) and melanoma (IPC298, IGR1) (Agarwal et al., 2010; Fraser SP, 2000; Grimes et al., 1995; Hemmerlein et al., 2006; Köhler et al., 2000; Mello de Queiroz et al., 2006; Laniado eet al., 2001; Malhi et al., 2000; Meyer et al., 1999; Pardo et al., 1999; Rane, 2000; Rouzaire-Dubois et al., 2000; Skryma et al., 1997; Woodfork et al., 1995);

2 - $\underline{\mathrm{Ca}^{+2} \text { Channels }}$ : pancreatic cancer (MIA PaCa-2 and CAV), breast cancer (MCF7/ADRR, MDA-231, MDA-231R44 and BT-474), melanoma (MM-RU, IGR1), prostate cancer (DU-145, PPC-1, PC3 and LNCaP) (Sato et al., 1994; Lambert et al., 1997; Kohn et al., 1996; Wasilenko et al., 1996; Benzaquen et al., 1995);

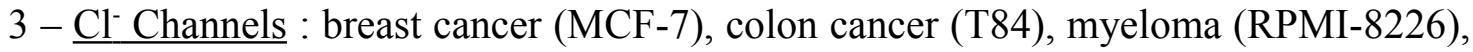
astrocitomas, glioma and rat glioma (C6) (Chou et al., 1995; Levitan \& Garber, 1995; Rouzaire-Dubois et al., 2000; Ullrich et al., 1996);

4 - $\underline{\mathrm{Na}^{+} \text {Channels: }}$ breast cancer (MCF-7), lung cancer (NCI-H146) and rat prostate cancer (Mat-LyLu and AT-2) (Blandino et al., 1995; Fraser SP, 2000; Grimes et al., 1995).

Although ion channels are directly related to proliferation and invasiveness of the tumors described above, the physiological mechanism these channels play remains a mystery to be unraveled. 
Besides cancer, there are several human genetic diseases that are related to mutations of structural genes of ion channels. Examples: the increased incidence of sudden cardiac death has been observed in patients that lack HERG currents because they carry a genetic defect. The mutations result in a diminished magnitude of potassium inwardly rectifying current consistent with the prolonged LQ interval observed in affected individuals (Dworakowska \& Dołowy, 2000). In pancreatic $\beta$ cells, ATP-sensitive potassium $\left(\mathrm{K}_{\mathrm{ATP}}\right)$ channels regulate glucose-dependent insulin secretion an serve as the target for sulfonylurea drugs used to treat type 2 and neonatal diabetes (Ashcroft, 2005; Ashcroft, 2010).

\subsection{Eag family of Ion Channels}

The ether-à-go-go (EAG) gene was first identified as a locus that caused legshaking in Drosophila melanogaster in response to ether anesthesia (Kaplan \& Trout, 1969). Subsequent cloning of the gene revealed that eag encodes a protein with structural similarities to voltage-gated potassium channels (Brüggemann et al., 1993; Warmke et al., 1991) which defines a novel family of potassium channels. The Eag family is formed for an extended gene family, with subsequently isolated members placed in eag, eag-like (elk) and eag-related genes (erg) subfamilies based on their sequences similarity. Sequence alignments of Drosophila, rat, mouse and human eag channel with cDNA libraries sequences show that these channels are structurally related with both voltage-gated $\mathrm{K}^{+}$channels and cyclic nucleotide-gated cation channels (Warmke \& Garnetzky, 1994). The first mammalian Eag channels cloned were mouse Eag1 (rEag1) and human Erg1 (Warmke \& Ganetzky, 1994). Since then, all subfamilies 
members have been cloned, in mammals two Eag channels (Eag1 (KCNH1, Kv10.1) (Ludwig et al., 1994), Eag2 (KCNH5, Kv10.2) (Saganich et al., 1999)), three Erg (Erg1 (Bauer et al., 1998), Erg2 and Erg3 (Shi et al., 1997)) and three Elk (Shi et al., 1998; Engeland et al., 1998; Gutman et al., 2005).

The human Eag1 and Eag2 (hEag1 and hEag2) channels possess 73\% homology, showing more divergence in the C-terminus region. Both channels are expressed in restricted areas of the central nervous system (Martin et al., 2008; Schönherr et al., 2002; Saganich et al., 1999) and their physiological function remains to be elucidated.

Despite the high homology at the protein level, the biophysical characteristics of Eag1 and Eag2 channels are different. The activation time constant of the Eag2 at +40 $\mathrm{mV}$ is four times slower than that of Eag1. Moreover, Eag2 current possesses a lower dependence on voltage, but the biggest difference between the two isoforms is the threshold potential for activation of the channel, much more negative for Eag2.

Both isoforms are able to interact and form heteromultimeric channels. The formation of these channels could increase the functional variability of Eag currents in regions of the central nervous system where there is overlapping expression. The physiological function of Eag2 is not yet known. In mammalians two splice variants have been cloned for hEag1, Eagla and Eaglb (Frings et al., 1998; Warmke \& Ganetzky, 1994), which forms an active ion channel, and a third one has been cloned in Drosophila, Eag80 that is composed by the N- and C-terminus of the channels and does not produce an active ion channel (Sun et al., 2009).

As all channels from the Kv family, the eag potassium channel likely forms a tetramer (Jenke et al., 2003). Each monomer is putatively formed by 6 transmembrane 
domains, $\alpha$-helical (S1-S6). The segment between S5 and S6 (P region) contributes to form the pore region of the channel. The $\mathrm{P}$ region is responsible for the selectivity of the channel. Another common feature to $\mathrm{Kv}$ channels is the S4 segment, crucial for voltage sensing, where positively charged residues involved in the initial conformational changes that lead to channel opening when the membrane depolarizes are located (Figure 1.2). These channels show a Per-Arnt-Sim(PAS) domain located in the N-terminus (Cabral et al., 1998). The C-terminus the channel shows a consensus sequence for cyclic nucleotide binding domain (cNBD), a calmodulin binding domain $(\mathrm{CaM})$ and a tetramerizing coiled coil domain (TCC) (Schönherr et al., 2000; Jenke et al., 2003; Warmke \& Ganetzky, 1994). 


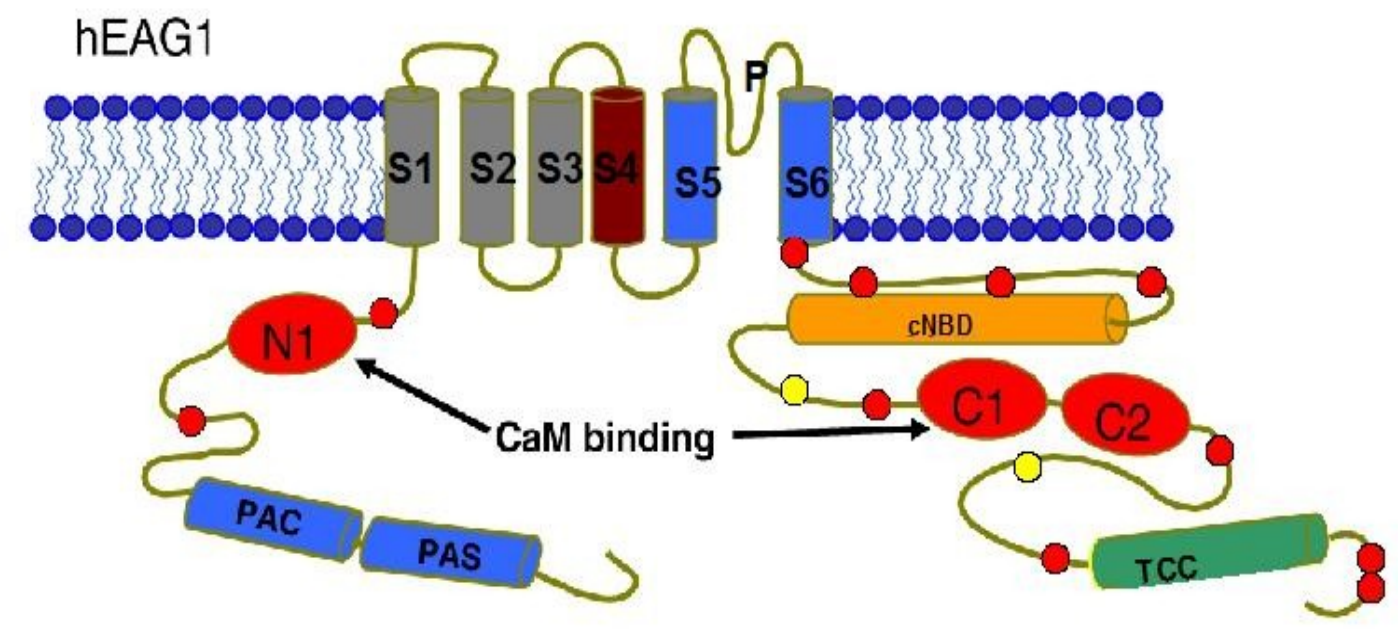

PKC binding site

PKA binding site

Figure 1.2 Putative structure of the Eag1 channel monomer. Transmembrane topology of an Eag1 $\alpha$-subunit content six transmembrane domain (S1-S6), where S4 is the voltage sensor and $\mathrm{P}$ is the pore region. (Adapted from http://www.sfb604.unijena.de/Project_A4_(Heinemann).html). 
Eag1 channels are expressed in most of the brain regions, and also in myoblasts (Bijlenga et al., 1998) as well as in many cancer cell lines and tumor tissues. Over 75\% of tumors tested were positive using specific antibodies for Eag1 (Meyer \& Heinemann, 1998; Pardo et al., 1998; Pardo et al., 1999; Hemmerlein et al., 2006; Mello de Queiroz et al., 2006; Agarwal et al., 2010), while inhibition of this channel decreased the proliferation of EAG expressing cells (Gavrilova-Ruch et al., 2002; Pardo et al., 1999; Gómez-Varela et al., 2007; Mello de Queiroz et al., 2006; Downie et al., 2008). Despite the efforts of several laboratories, the physiological role of Eag1 in the brain remains elusive.

The activation kinetics of the channel is dramatically slowed down by negative pre-pulses potential. This phenomenon is reminiscent of the "Cole-Moore shift" (Cole \& Moore, 1960), shared by other potassium channels, but orders of magnitude larger. The shift is also dependent on extracellular $\mathrm{Mg}^{+2}$, which binds to the extracellular hydrophilic loop between S2 and S3 and slows channel gating (Terlau et al., 1996; Silverman et al., 2000). Intracellular $\mathrm{Ca}^{+2}$ block the channel by calmodulin binding to the hEag N- and C-terminus (Stansfeld et al., 1996; Schönherr et al., 2000; Schönherr et al., 2004).

Eag1 channels show low sensitivity to classical blockers, like TEA, 4-AP and the ERG channel blocker E4031. Quinidine blocks the hEag1 with a $\mathrm{IC}_{50}$ of $1.4 \pm 0.06$ $\mu \mathrm{M}$, while the $\mathrm{IC}_{50}$ for the hEag2 channel is $151,8 \pm 24.8 \mu \mathrm{M}$, around 100 times less sensitive. Therefore quinidine can be used to pharmacologically differentiate the isoforms of Eag channels (Schönherr et al., 2002).

Other drugs capable of blocking the hEag1 channel are: imipramine (tricyclic antidepressant) and astemizole (antihistamine). Imipramine is able to block several 
types of ion channels including hERG, $\mathrm{Na}^{+}, \mathrm{Ca}^{+2}$, voltage-gated $\mathrm{K}^{+}$channels, $\mathrm{Ca}^{+2}-$ gated $\mathrm{K}^{+}$channels. In all cases, the $\mathrm{IC}_{50}$ for all these channels range from 1 to $30 \mu \mathrm{M}$. The fact that different ion channels show comparable affinities for imipramine suggests structural conservation at the binding site across these very diverse ion channels targets. Imipramine blocking mechanism is strongly voltage-dependent; it has a binding site in the intracellular side of the open channels (García-Ferreiro et al., 2004).

In contrast to imipramine, the actions of astemizole are more restricted. For example, concentrations up to $10 \mu \mathrm{M}$ astemizole have no effect on other $\mathrm{K}^{+}$channels, such as the voltage-gated $\mathrm{K}^{+}$channels $\mathrm{Kv} 1.1, \mathrm{Kv} 2.1, \mathrm{Kv} 4.2$ and IRK1 inward rectifier $\mathrm{K}^{+}$channels (Suessbrich et al., 1996). Eag-like channels $2\left(\mathrm{hELK}_{2}\right)$ are also not sensitive to astemizole (Becchetti et al., 2002). HERG channels are highly sensitive to astemizole with $\mathrm{IC}_{50} 50 \mathrm{nM}$ (Suessbrich et al., 1996; Barros et al., 1997). This suggests structural conservation in the architecture of HERG and hEag1 that supports the selective inhibition by this drug.

The astemizole blocking mechanism is very similar to imipramine, but block by astemizole does not show the voltage dependence that is essential for the imipramine action (García-Ferreiro et al., 1994).

\subsection{Eag1 and cancer}

Overexpression of rEag potassium channels in $\mathrm{CHO}$ or NIH $3 \mathrm{~T} 3$ cells induces the hallmarks of malignant transformation: faster growth, loss of growth-factor- and substrate-dependence, and loss of contact inhibition. Furthermore, Eag1 is expressed ectopically in human cancer cell lines and the expression of hEag represents an 
advantage for the progression of tumors in SCID mice in vivo (Pardo et al., 1999). These findings, together with the strong modulation of Eag channels during the cell cycle, strongly suggest a direct involvement of Eag protein in cell proliferation and the participation in the pathogenesis of some tumors. This hypothesis is additionally supported by results reported from myoblasts (Bijlenga et al., 1998; Occhiodoro et al., 1998) since Eag is expressed over a short time frame immediately preceding myoblast fusion, a proliferation-related phenomenon (Pardo et al., 1999).

In Xenopus oocytes, activation of mitosis promoting factor (MPF) produces changes in the behavior of heterologously expressed Eag1 (Brüggemann et al., 1997). The biophysical properties of this channel are modified by the cell cycle, and this modulation has two characteristics: 1) in $\mathrm{CHO}$ cells, a current density reduction in $\mathrm{M}$ phase 2) increase the selectivity for $\mathrm{K}^{+}$in mitosis phase and concomitant increased block sensitivity by intracellular $\mathrm{Na}^{+}$(Pardo et al., 1998; Camacho et al., 2000).

Many cell lines show positivity for Eag1, such as SH-SYS5 (human neuroblastoma (Meyer \& Heinemann, 1998)), EFM-19 and MCF-7 (breast cancer), HeLa (cervix carcinoma (Pardo et al., 1999)) and IGR1 and IPC298 (melanoma (Gavrilova-Ruch et al., 2002; Meyer et al., 1999)). In these cell lines, inhibition of hEag expression by antisense oligonucleotides leads to a reduction of DNA synthesis (Pardo et al., 1999).

Because its expression is limited to the central nervous system in normal adult tissue, Eag1 might be a tumor marker. Furthermore, using a specific inhibitor for the Eag1 channel could decrease tumor proliferation rate making the Eag1 channel a promising candidate for therapy. 


\subsection{Splice Variants}

Most of the human protein-coding genes exhibit an exon-intron structure that becomes apparent when their pre-mRNA is processed. During pre-mRNA processing, some sequences are joined and exported into the cytosol as exons (for exported sequences). The introns (intervening sequences) are excised and retained in the nucleus (Sumanasekera et al., 2008).

In humans, almost all RNA polymerase II transcripts are spliced, and an estimated $74-88 \%$ of human genes are alternatively spliced (Kampa et al., 2004). Most of the alternative exons encode portions of proteins, and therefore alternative splicing generates multiple protein isoforms from a single gene. These isoforms often have different biological properties in that they interact with other binding partners and possess different subcellular localizations, catalytic activities or pharmacological properties (Stamm et al., 2006). Several biological processes are co-ordinate by orchestrated changes in alternative splicing. Well-studied examples of these processes include sex determination in Drosophila (Forch et al., 2003) and certain apoptotic events (Wu et al., 2003).

Alternative splicing (AS) is often regulated in a temporal or tissue-specific fashion. This gives rise to different protein isoforms in different tissues or developmental states; differential splicing is also regulated in response to external stimuli. Even a single cell may produce multiple proteins.

Alternative splicing is regulated by "quality control mechanisms" like the cytoplasmic degradation of mRNAs by the nonsense mediated mRNA decay (NMD) pathway which eliminates inappropriately spliced forms (Garcia-Blanco et al., 2004). 
Alternatively spliced proteins are the prime cause of some diseases, for example cystic fibrosis, retinitis pigmentosa, spinal muscular atrophy, neurofibromatosis type I, haemophilia A and Beta - thalassaemia (Pajares et al., 2007), FTDP-17 (frontotemporal dementia and parkinsonism linked to chromossome 17) and Duchenne's muscular dystrophy. The deregulation of the cellular splicing machinery, as exemplified by the numerous changes in alternative splicing seen in cancer, in some cases may be causing aberrant splicing (Venables, 2006).

The lack of compounds for the activation or inhibition of specific pre-mRNA splicing events is a problem for studying the splicing reaction itself and for the generation of therapeutic approaches to treat diseases caused by missplicing.

\subsubsection{Alternative pre-mRNA splicing}

A gene is first transcribed into a pre-mRNA, which is a copy of the genomic DNA containing intronic regions intended to be removed during pre-mRNA processing (RNA splicing), as well as exonic sequences that are retained within the mature mRNA. During RNA splicing, exons can either be retained in the mature message or targeted for removal in different transcripts, referred to as alternative RNA splicing (Lopez, 1998).

Pre-mRNA splicing is an essential, precisely regulated process that occurs after gene transcription and prior to mRNA translation. Pre-mRNA splicing begins with the ordered assembly and coordinated action of the particles U1, U2, U4, U5 and U6 snRNPs ( small nuclear ribonucleoprotein particles) and non-snRNP proteins on the premRNA. Each snRNP particle contains a small nuclear RNA molecule (snRNA) and 
several proteins. The complex of snRNPs and non-snRNPs is called the spliceosome (Burge et al., 1998).

Pre-mRNA splicing is a mechanism that removes intronic sequences and joins their surrounding exons. The mature mRNA is exported from the nucleus to the cytoplasm where it can be translated into proteins.

There are five main types of splicing mechanisms which are described in Figure 1.3.

A) RNA splice, which introns are removed and exons are joined

B) Exon skipping, this is the most common type of alternative splicing (AS), it contributes at least one third of AS events which involve cassette - type alternative exons which are either skipped or included in the final message (exons are included or excised from the final gene transcript leading to extended or shortened mRNA variants).

C) Alternative donor site happens when an alternative 5' splice junction (donor site) is used, changing the 3 ' boundary of the upstream exon.

D) Alternative acceptor site happens when an alternative $3^{\prime}$ splice junction (acceptor site) is used, changing the 5' boundary of the downstream exon.

E) Intron retention can account for $3 \%$ of total AS events. 


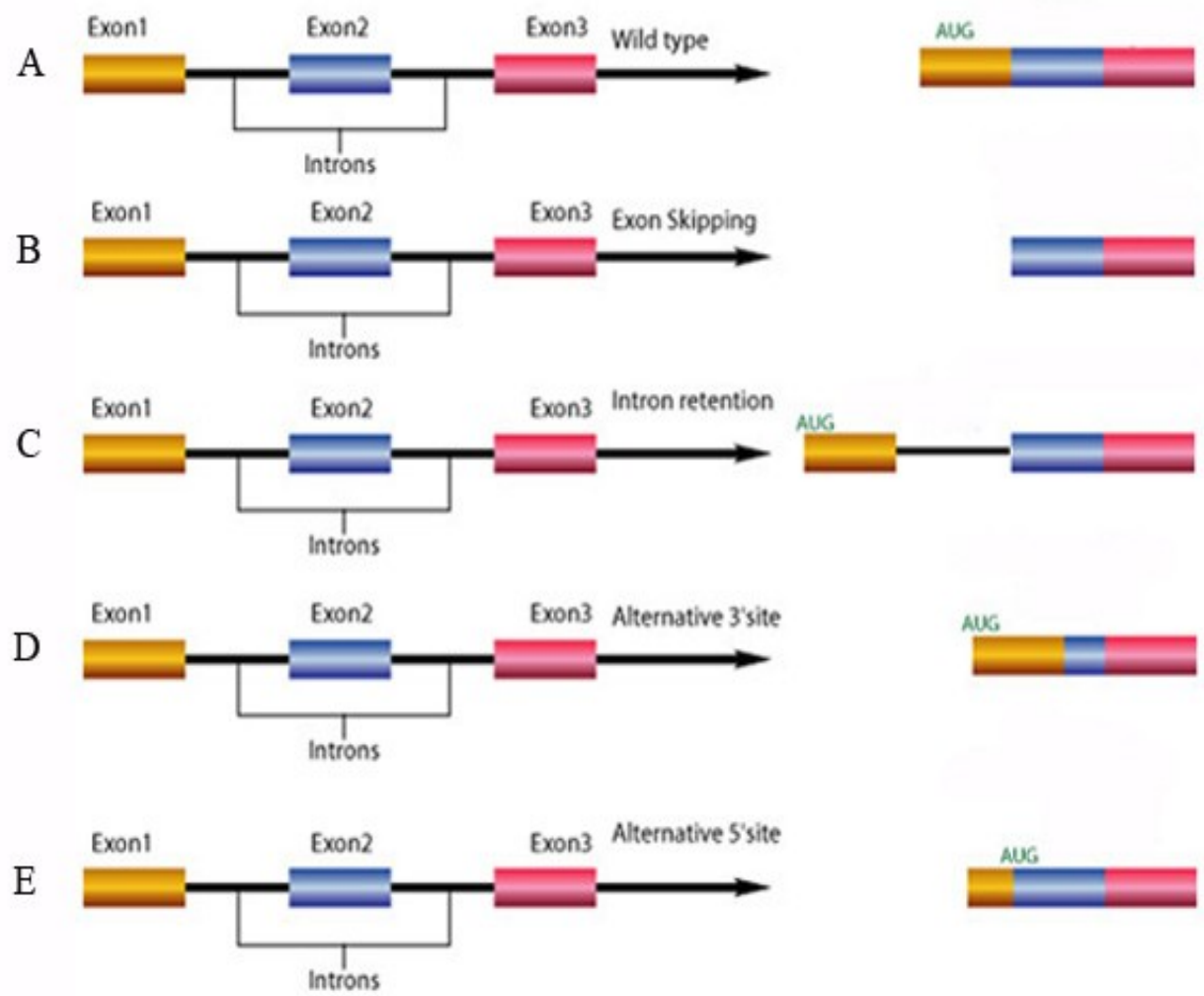

Figure 1.3 Schematic view of constitutive and alternative splicing. A represents the wild-type genome sequence for a hypothetical gene, B represents the most common alternative splicing, $\mathrm{C}$ represents intron retention and $\mathrm{D}$ and $\mathrm{E}$ represents the $5^{\prime} / 3^{\prime}$ donor/acceptor site. 


\subsubsection{Alternative splicing and cancer}

Various cell types and developmental stages regulate alternative splicing patterns differently in their generation of specific gene functions. In cancers, the splicing process is significantly altered.

Alternative and aberrant pre-mRNA splicing may play an important functional role in human cancers. The expression of alternative (even tumor-specific) splice variants has been shown to significantly affect aspects of cancer biology (such as proliferation, motility and drug response), although global, genome wide analyses are only now emerging. A number of reviews have addressed this topic recently (Blencowe, 2006; Brinkman, 2004; Kalnina et al., 2005; Venables, 2004; Venables, 2006).

Cancer-related splice variants have a great potential to serve as unique biomarkers for diagnostic and even therapeutic purposes. For example, a specific splice variant of CD44 (the "v6-variant"), found preferentially in head and neck cancers (Herrlich et al., 2000) can form a stimulatory complex with hepatocyte growth factor (HGF) and its tyrosine kinase receptor MET, which is then able to activate the Ras signaling pathway. These splice variant has been exploited for specifically targeting tumor cells with therapeutic antibodies (Heider et al., 2004).

Somatic splice-site mutations and single-nucleotide-polymorphisms (SNPs) which cause aberrant splicing are known for a number of familial cancer syndromes and the corresponding tumor suppressor genes such as BRCA1, APC, p53, FHIT and LKB1 (Hastings et al., 2005; Orban \& Olah, 2003; Venables \& Burn, 2006), and for example, the prostate cancer susceptibility gene KLF6 (Narla et al., 2005a; Narla et al., 
2005b). In general, it has been estimated that splice-site mutations contribute to approximately $10-15 \%$ of the total number of somatic mutations known in cancer (Beroud et al., 2005). This is likely to be an underestimate, provided that many cancergene sequencing approaches are biased towards the exons, and non-coding SNPs may also contribute to splice-site alterations (ElSharawy et al., 2006; Fairbrother et al., 2004).

Still is unclear if, and to what extent, AS functionally contributes to the initiation and progression of cancers, or if altered splicing patterns could be largely symptomatic and attributed to a generalized lack of fidelity of the splicing apparatus in cancer cells. Accordingly, it is unclear if particular splice variants in cancer are contributing to the cancer phenotype, or if their existence is merely a consequence of the malignant phenotype (Skotheim \& Nees, 2007).

The persistence of novel splice variants as a result of the process of clonal selection may be the critical parameter required to address the topic properly. It is likely that cells expressing certain AS variants are positively selected for in tumor progression. This would for example be the case when the splice variant encodes protein isoforms that provide advantages such as increased proliferation, anti-apoptotic or pro-angiogenic effects, enhanced cell motility or tumor cell survival. Moreover, it becomes increasingly clear that such micro-evolutionary processes in tumors are indeed likely to exploit splice variants for gaining such functional advantages, in combination with other mutational and genetic events ( Skotheim \& Nees, 2007).

It is also becoming apparent that AS contributes to expand or restrict the capabilities and potential of stem cells, which are increasingly viewed as central to cancer biology (Lemischka \& Pritsker, 2006; Pritsker et al., 2005; Pritsker et al., 2006). 


\subsection{Melanomas}

Melanoma is a rapidly proliferating and highly aggressive form of skin cancer that is difficult to treat once the tumor has metastasized beyond the original area. This tumor occurs when melanocytes, which are the cells that give rise to the color of the skin, become malignant. They can grow and spread to the lymph nodes and to the other parts of the body such as liver, lungs or brain. Melanoma responds poorly to chemoand radiotherapy (Gavrilova-Ruch et al., 2002).

The incidence of melanoma is rising faster than any other malignancy (Jemal et al., 2006; Thompson et al., 2005; Balch et al., 2003; Desmond \& Soong, 2003). Bataille \& Vries, 2008, quote that in Europe, cutaneous melanoma represents $1-2 \%$ of all malignant tumors. Overall, 18.000 new diagnoses and 5.000 deaths from melanoma are registered in Europe every year.

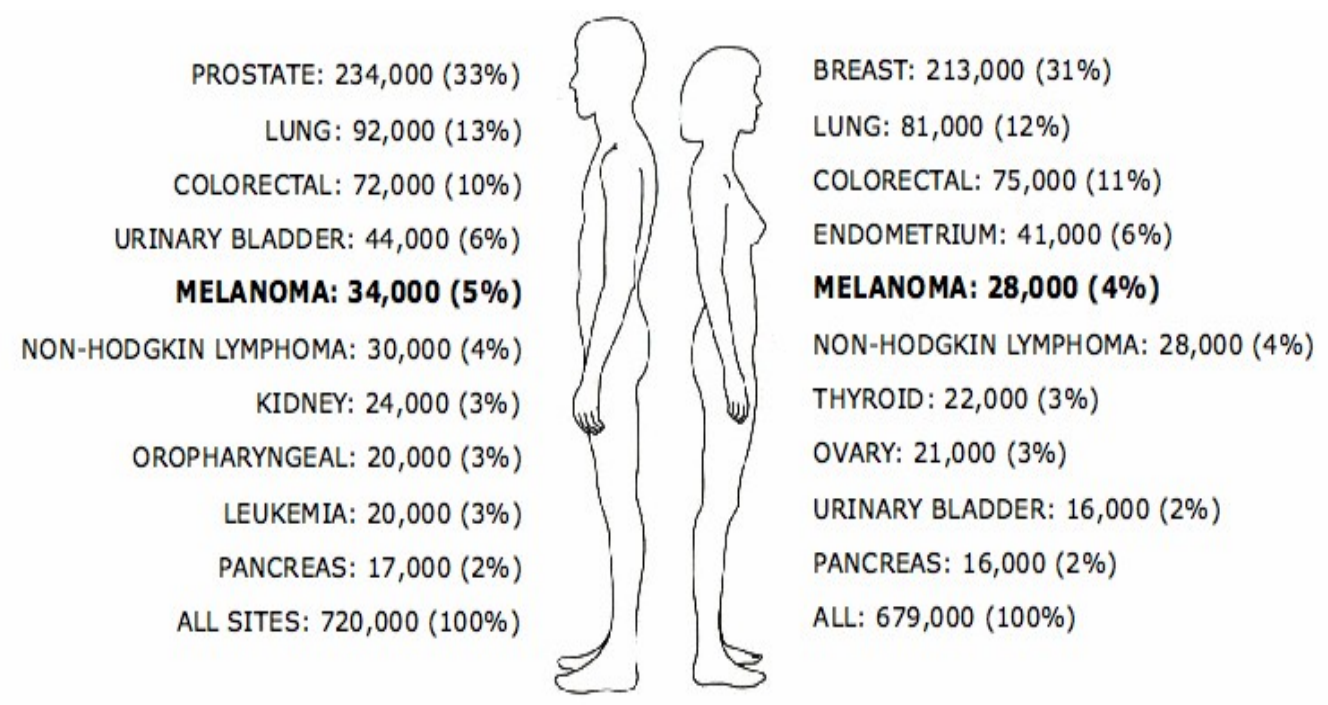

Figure 1.4 Annual incidence of new cases (and relative frequency) of malignant tumors in the USA. The incidence is shown here and classified by gender. Source: American Cancer Society: Cancer Facts and Figures, 2002. 
The most important aspect of the primary melanoma lesion is tumor thickness (measured in millimeters, Breslow depth) and the presence or absence of ulceration (Balch et al., 2001a; Balch et al., 2001b). Microstaging primarily utilizing these factors determines the appropriated therapy and prognosis. Poor prognosis correlates with deep Breslow depth and the presence of ulceration. A person with a melanoma detected and treated at an early stage has an excellent prognosis (Balch et al., 2001a; Balch et al., 2001b; Chang et al., 1998). The five-year survival rate ranges from greater than $95 \%$ for those diagnosed with a melanoma less than $1.00 \mathrm{~mm}$ thick with no ulceration to a $30 \%$ five-year survival rate for those with a melanoma greater than $4.00 \mathrm{~mm}$ thick with ulceration (Rigel et al., 2000).

Advanced melanoma represents therefore a still current medical need, and consequently novel molecular targets and markers are actively searched for.

Manipulation of $\mathrm{K}^{+}$channel function is a very important tool in controlling melanomas (Schönherr, 2005). Schönherr (2005) shows the importance of $\mathrm{K}_{\mathrm{ca}} 3.1$ (calcium-activated potassium channel) and Eag1 for the control of the proliferation of several human melanoma cell lines. In addition, a microarray of different melanocytes comparing 80 different genes for $\mathrm{K}^{+}$channels, revealed a consistent upregulation of $\mathrm{K}_{\mathrm{Ca}}$ 3.1. Further studies on fresh tissue of melanoma revealed the expression of $\mathrm{K}_{\mathrm{Ca}} 3.1$ in $80 \%$ of the cases and $\mathrm{K}_{\mathrm{V}} 10.1$ in $50 \%$ of the cases. Under hypoxia, a commonly condition found in tumors, $\mathrm{K}_{\mathrm{Ca}} 3.1$ was upregulated maybe facilitating tumor progression.

Eag1 $\mathrm{K}^{+}$channels in human melanoma cells contribute to cellular proliferation and may provide initial hyperpolarization for the progression into the G1 phase of the 
cell cycle (Gavrilova-Ruch et al., 2002). Ion channels are viable pharmacological targets for the treatment of many diseases, and there is overwhelming confidence that they will have significant potential in diagnosis, prognosis and, importantly, therapy. Indeed, this optimism is supported by some recent publications (Fiske et al., 2006; Downie et al., 2008; Gray \& Macdonald, 2006; Mello de Queiroz et al., 2006; Hemmerlein et al., 2006; Weber et al., 2006; Barajas Farias et al., 2004; Gómez-Varela et al., 2007; Stühmer et al., 2006; Pardo, 2004; Pardo, 2005; Hoang et al., 2007; Roger et al., 2006; Schönherr, 2005; Villalonga et al., 2007; Pardo et al., 1999;).

The potential of ion-channel inhibitors in the control of tumor development has been confirmed at the clinical setting by the use of chlorotoxin, a selective inhibitor of a chloride channel (ClC-3), involved in the invasive process (Veiseh et al., 2009). The recently developed radiolabelled compound Cltx $\left(\mathrm{I}^{131}-\mathrm{Cltx}\right)$ has successfully completed phase I and II of clinical trials for patients with late-stage gliomas (Mamelak et al., 2006; Ernest \& Sontheimer, 2007) and a multi-centre phase III is now recruiting patients (Cuddapah \& Sontheimer et al., 2010).

Ion channels are proteins in the membrane that might activate intracellular pathways, independent of their permeation properties, through sites or domains in different regions of the channel. These properties might explain the influence of the channels in the membrane on intracellular processes involving enzyme activation and/or protein synthesis such as cell proliferation. 


\subsubsection{The melanoma cell line IGR39}

IGR39 cell line originated from the primary achromic cutaneous tumor (left thigh) of a 26-year-old man with malignant melanoma (Aubert et al., 1980).

Meyer and colleagues (1999) investigated the functional properties in melanoma cells and they described that IPC298 and IGR1, two other melanoma cell lines, express Eag1 channel, whereas IGR39 cells do not express Eag1, and only express typical delayed-rectifier channels. Since then, this cell line has been used as a negative control in experiments with Eag1.

In a proliferation experiment using astemizole, a known drug that blocks hEag1 channels (Garcia-Ferreiro et al., 2004), using different cancer cell lines, we observed that the cell line IGR39, our negative control, showed in its proliferation rate some sensitivity to block by astemizole (Figure 1.5). The cell line IPC298 is much more sensitive to proliferation block by astemizole as we can see below.

IPC298

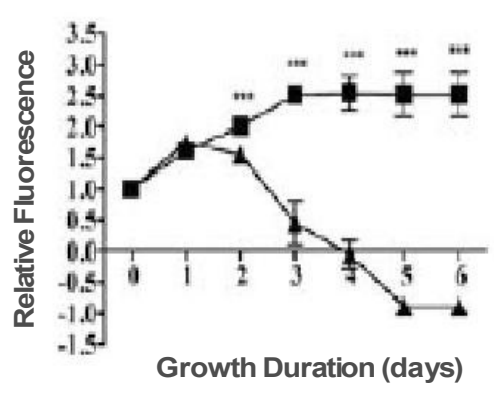

IGR39

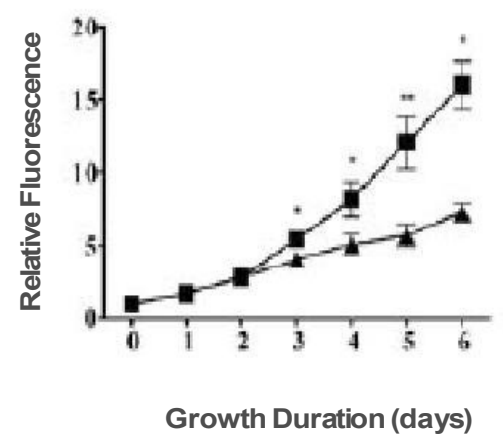

Figure 1.5 Astemizole reduces proliferation in melanoma cell lines. The ( $\boldsymbol{\square})$ represents norastemizole, and $(\boldsymbol{\Delta})$ astemizole. Norastemizole is an inactive form of astemizole, and it was used as a control. In IPC298 cells the proliferation was strongly reduced by astemizole treatment, while in IGR39 cells was a small, but significant reduction (Weber, $\mathrm{PhD}$ Thesis, 2006). 
In IGR39 cells the astemizole-dependent reduction of the proliferation was smaller, suggesting that in this cell line the proliferation mechanism is not mostly regulated by astemizole-sensitive ion channels.

Through RT-PCR using nine different pairs of primers, we saw that the IGR39 cell line was positive for Eag1, to an extent close to IPC298, another melanoma cell line, the human brain positive control and the transfected HEK293-Eag1cells (Figure 1.6).

hBrain

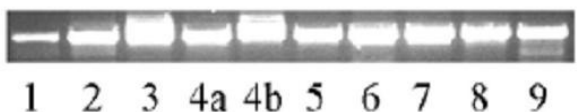

HEK-hEAGla

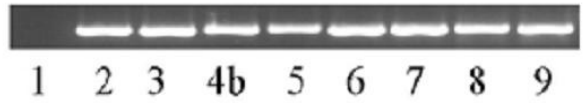

IPC298

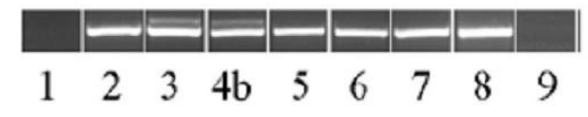

IGR-39

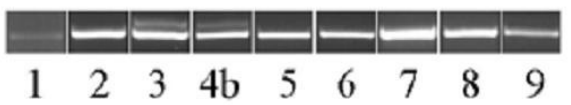

Figure 1.6 RT-PCR for Eag1 in melanoma cell lines. To amplify the Eag1 sequence were used nine different pairs of primers located in different regions of the Eaglaa sequence (Weber, $\mathrm{PhD}$ Thesis, 2006).

The expression of the ion channel protein can be detected also by antibody reaction. In an immunocytochemistry experiment, shown in Figure 1.7, we see that when we used an antibody against the pore region of the Eag1 channel (C and D), both melanoma cell lines, IPC298 and IGR39 were positive for Eag1. However, when the antibody utilized was against the C-terminus (A and B) of the channel we just detected the signal in the IPC298 cell line. We conclude that the antibody against the C-terminus 
can not binding in IGR39 cells. We can also notice that the binding of the antibody against the pore region in IGR39 cell line a much more prominent membrane localization than the one detected in the IPC298 cell line. Why do the antibodies stain differently?

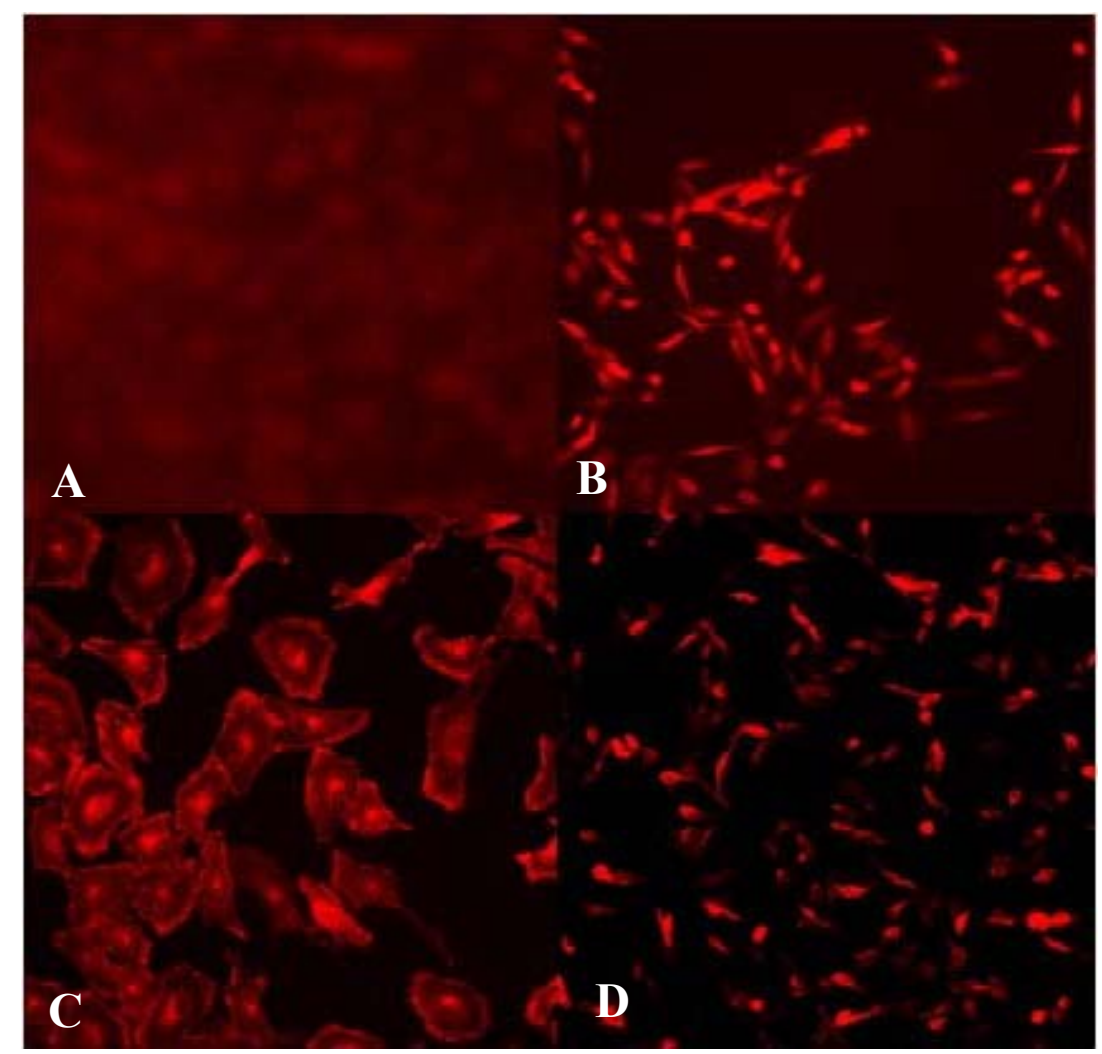

Figure 1.7 Eag1 immunostaining in melanoma cell lines. (A) and (B) show the antibody staining against the C-terminus of the channel, and (C) and (D) the antibody staining against the pore region of the channel. In (A) and (C) is the staining for IGR39 cell line, and in (B) and (D) shows the staining for the IPC298 cell line (A. Sanchez, unpublished).

Based on these data from our laboratory, divergent from literature data, we decided to characterize the expression of Eag1 in these melanoma cell lines. 


\section{Aims}

\subsection{General Aim}

To characterize the potassium channel Eag1 present in the melanoma cell lines IGR39 and IPC298.

\subsection{Specific Aims}

To characterize the properties of Eag1 expressed in IGR39 and IPC298 melanoma cell lines.

To investigate the biophysical characteristics of Eag1 from IGR39 and IPC298 cells.

To investigate the sequence of Eag1 from IGR39 and IPC298 cells.

To investigate the subcellular localization of Eag1 from IGR39 cells. 


\section{$3 \quad$ Materials \& Methods}

\subsection{Cell Culture}

Cell lines HEK293 (ECACC 85120602), IPC298 (DSMZ ACC251) and IGR39 (DSMZ ACC239) were obtained from DSMZ (Braunschweig, Germany). Each cell line was propagated and maintained according to the instructions of the corresponding provider, HEK293 cells were maintained in Dulbecco's MEM + 10\% FCS, IPC298 in RPMI $1640+10 \%$ FCS and IGR39 in Dulbecco's MEM + 15\% FCS. For transfected cells, the selection compound Zeocin (Calya) was added to the culture medium at 3 $\mu \mathrm{g} / \mathrm{ml}$. Transient transfections were performed using Fugene (Roche Applied Science).

The Fugene transient transfections were performed using $15 \mu 1$ of Fugene transfection reagent plus $185 \mu 1$ of OptiMen medium without serum (Gibco). This mixing was called tube 1 , and it was incubated at room temperature for 5 minutes. In a tube $2,1 \mu \mathrm{g}$ of the DNA construct was mixed with OptiMen to a final volume of $200 \mu 1$. After the 5 minutes incubation, the $200 \mu$ l of tube 1 was added directly inside the solution in tube 2 . The mixing was incubated at room temperature for 15 minutes. The $400 \mu 1$ was added directly in a $5 \mathrm{ml}$ normal supplemented medium T25 $\left(25 \mathrm{~cm}^{2}\right)$ cell culture bottle and wait 48 hours. 


\subsection{Drugs}

Astemizole and MG115 (Sigma) were diluted from a DMSO stock solution. The final concentration of DMSO was always $0.1 \%$, a concentration that showed no effects on hEag1 currents (data not shown). Imipramine and Chloroquine (Sigma) were used from stock in distilled water. Progesterone (Sigma) was diluted in ethanol.

\subsection{Molecular Biology}

\subsubsection{Total RNA isolation and cDNA synthesis}

Total RNA was obtained from cell pellets (using RNeasy, Qiagen, Hilden, Germany). Samples ( $5 \times 10^{6}$ cells) were disrupted in buffer containing guanidine isothiocyanate and homogenized. Ethanol was then added to the lysate, creating conditions that promoted selective binding of RNA to the RNeasy silica-gel membrane (RNeasy Kit, Qiagen). Total RNA bound to the membrane, contaminants were washed away, and a DNase treatment was performed to eliminate genomic DNA. After wash steps, the RNA was eluted in RNase-free water. 


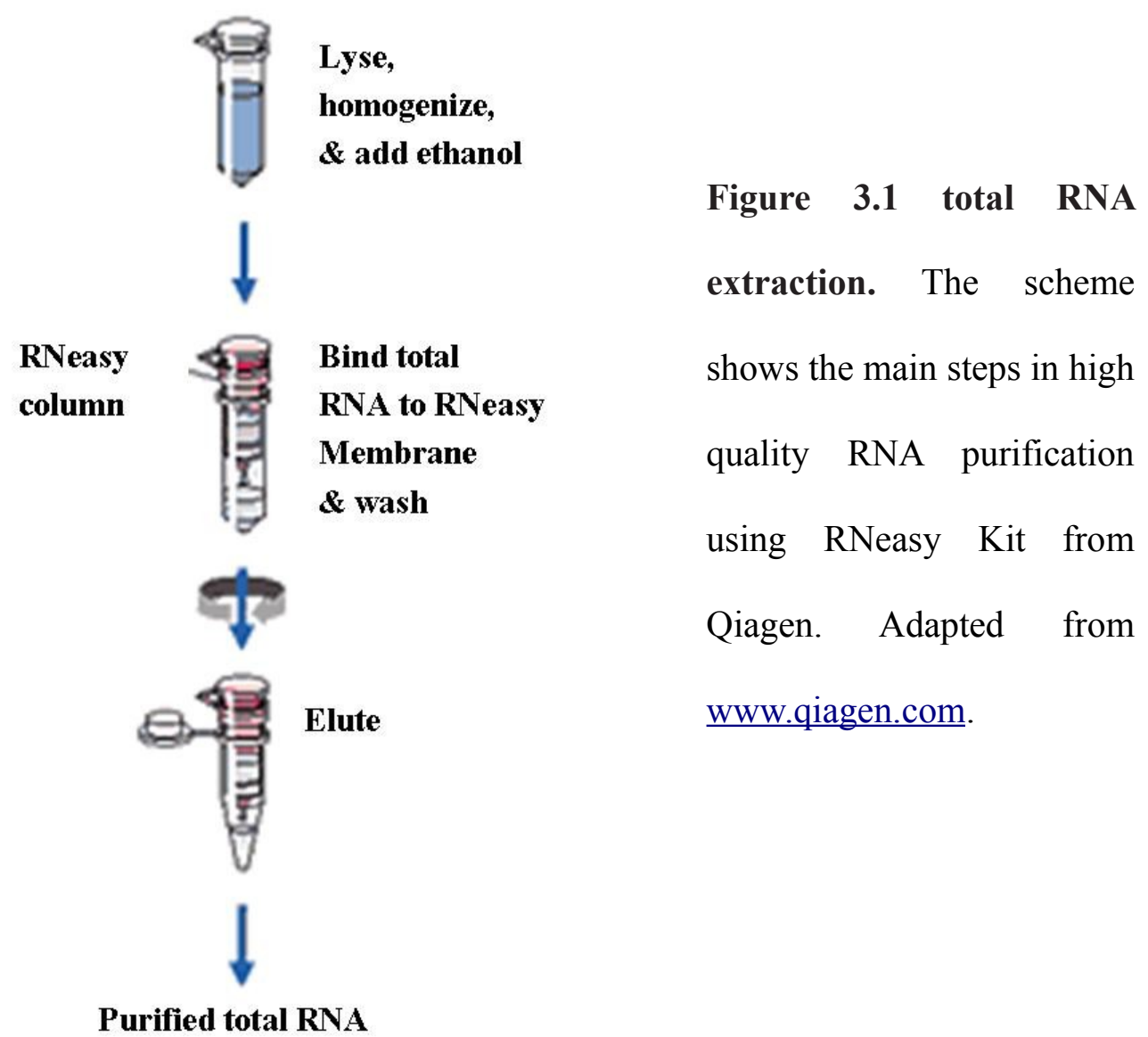

cDNA was synthesized from $2.5 \mu \mathrm{g}$ of total RNA. Was added to the samples $1 \mu \mathrm{l}$ Oligo (dT) 12-18 and DEPC-water to advice a RNA concentration of the final volume of $12 \mu \mathrm{l}$ and a RNA concentration of $0.2 \mu \mathrm{g} / \mu \mathrm{l}$. At each step the samples were mixed by vortexing and collected by brief centrifugations. The reaction mixture was heated at $70^{\circ} \mathrm{C}$ for 10 minutes and rapidly cooled on ice for 1 minute. Subsequently was added reaction buffer containing: $2 \mu \mathrm{l}$ of reverse transcriptase buffer $10 \mathrm{x}$ concentrated, $2 \mu \mathrm{l}$ $\mathrm{MgCl} 225 \mathrm{mM}, 2 \mu \mathrm{l}$ of DTT $0.1 \mathrm{~mm}$ and $1 \mu \mathrm{l}$ of dNTPs $10 \mathrm{mM}$. The reaction mixture was heated for 5 minutes and to the negative samples $1 \mu$ of DEPC-water was added, and to the positive samples $1 \mu$ of reverse transcriptase enzyme was added. After the addition 
of enzyme or water, the samples were incubated for 50 minutes at $42^{\circ} \mathrm{C}$ and then for 15 minutes at $70^{\circ} \mathrm{C} .1 \mu \mathrm{l}$ of RNase was added to degrade RNA present in the samples in order to avoid possible contamination in a PCR. The reaction mixture was incubated for 20 minutes at $37^{\circ} \mathrm{C}$. At the end of the procedure $4 \mu \mathrm{l}$ of DEPC-water were added to advice a reaction volume of $25 \mu \mathrm{l}$ with final concentration of cDNA of $0.1 \mu \mathrm{g} / \mu \mathrm{l}$. All reagents used for cDNA synthesis were from SuperScript First-Strand Synthesis Kit (Invitrogen).

The mRNA for the northern-blot experiments was obtained directly from fresh cells. Samples (up to $1 \times 10^{7}$ cells) were washed with cold PBS and the lysis was done in $1 \mathrm{ml}$ of Lysis/Binding Buffer ( $\mu$ MACS mRNA isolation kit - MACS molecular) with strong vortexing for 3-5 minutes. The lysate was applied to a LysateClear Column which was centrifuged at $13.000 \mathrm{xg}$ for 3 minutes. The cleared lysate was collected in the centrifugation tube. Cell debris was removed using LysateClear Column. During the centrifugation the $\mu \mathrm{MACS}$ separator is prepared in a magnetic field of an appropriated magnetic rack. The columns were rinsed once with 100 $\mu$ Lysis/Binding Buffer and following $50 \mu 1$ per $1 \mathrm{ml}$ lysate of Oligo(dT)MicroBeads was added to the separator. The lysate was added on top of the column matrix and the lysate was left to pass through while the magnetically labeled mRNA was retained in the column. Subsequently, the column was rinsed 2 times with $200 \mu 1$ of Lysis/Binding Buffer to remove proteins and DNA. After that, the column was washed 4 times with $100 \mu 1$ of Wash Buffer to remove rRNA and DNA. A pre-elution step was performed, and $27 \mu 1$ of a pre-heated $\left(70^{\circ} \mathrm{C}\right)$ Elution Buffer was added to the column. The elution was then performed using $50 \mu 1$ of pre-heated Elution Buffer in a magnetic field. 


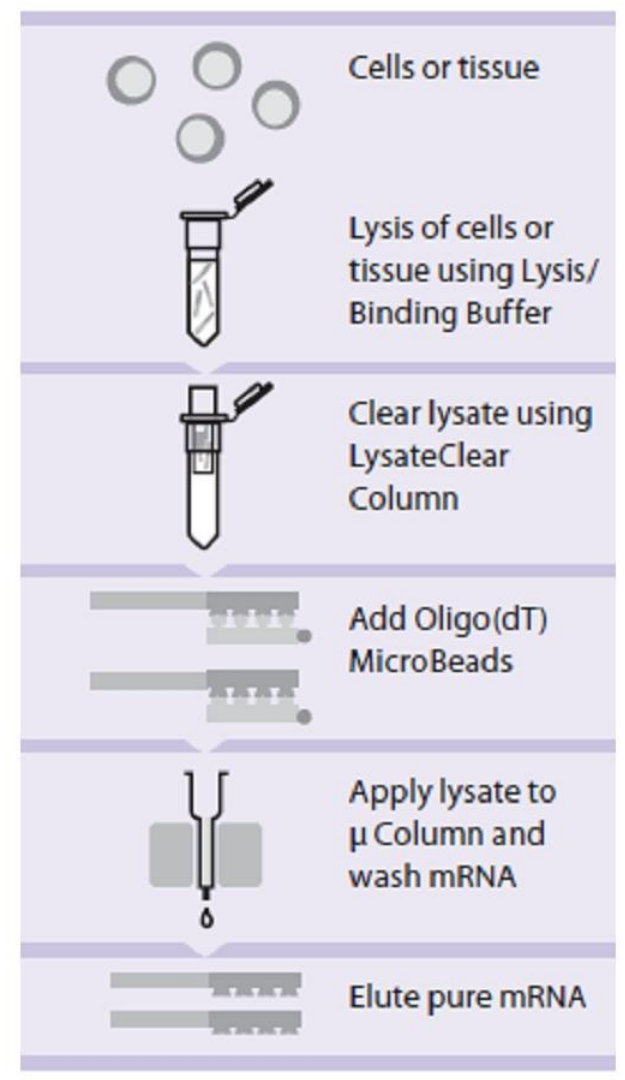

Figure $\quad 3.2 \quad$ mRNA extraction. The scheme shows the main steps in high quality mRNA purification using $\quad \mu$ MACS mRNA isolation kit from MACS Molecular. Adapted from www.miltenyibiotec.com.

RNA and DNA concentration, purity and yield were determined by optical density (OD) measurements at 260 and $280 \mathrm{~nm}$ using a spectrophotometer (Implen Nanophotometer UV/VIS).

\subsubsection{Endonuclease digestion}

First-strand cDNA from $2.5 \mu \mathrm{g}$ total RNA was mixed with synthetic deoxyoligonucleotide (Table 1) complementary to the intended exon with two 3' unpaired nucleotides to a final concentration of $1 \mu \mathrm{M}$ in a volume of $50 \mu 1$. The mixture was applied at $94^{\circ} \mathrm{C}$ for 2 minutes, $85^{\circ} \mathrm{C}$ for 15 minutes, $70^{\circ} \mathrm{C}$ for 15 minutes, $55^{\circ} \mathrm{C}$ for 
15 minutes, and room temperature for 15 minutes. Then $15 \mathrm{U}$ restriction endonuclease were added, and samples were incubated at $37^{\circ} \mathrm{C}$ for 2 hours.

\begin{tabular}{|l|l|l|}
\hline \multicolumn{1}{|c|}{ Target } & \multicolumn{1}{c|}{ Sequence } & \multicolumn{1}{c|}{ Enzyme } \\
\hline $\begin{array}{l}\text { Eag1 } \\
\text { exon 6a }\end{array}$ & $\begin{array}{l}\text { 5'-GTCCTGTTTGCCATATGATGTCATC } \\
\text { AACGCTTTTcc-3 }\end{array}$ & NdeI \\
\hline $\begin{array}{l}\text { Eag1 } \\
\text { exon } 7\end{array}$ & $\begin{array}{l}\text { 5'-GCATTGGGGACTATGAGATCTTTG } \\
\text { ACGAGGACACtt-3' }\end{array}$ & BglII \\
\hline $\begin{array}{l}\text { Eag1 } \\
\text { exon } 10\end{array}$ & $\begin{array}{l}\text { 5'-GATCTGCATGTGATCAAGCGGGA } \\
\text { cc-3' }\end{array}$ & BclI \\
\hline $\begin{array}{l}\text { Eag1 } \\
\text { exon } 11\end{array}$ & $\begin{array}{l}\text { 5'-CAATGTCCTTACAGAGCATGCCTCC } \\
\text { GCCAACCACcc-3' }\end{array}$ & SphI \\
\hline
\end{tabular}

Table 1 - Deoxyoligonucleotides used in cleavage of cited exons. Underlined uppercase indicates cleavage site; underlined lowercase indicates unpaired 3' tail.

The digested cDNA was directly used in a PCR reaction as described in section 3.6 .

\subsubsection{Plasmids, constructs and cRNA preparation}

From the splice variants cloned in pGEM-T and Eag1 in pSGEM, we cut with two enzymes, AarI (Fermentas) and BspEI (New England BioLabs), and exchanged the fragment. The ligation was performed using the Quick Ligation Kit (New England BioLabs), we combined $50 \mathrm{ng}$ of the digested pSGEM-Eag1 with a 3-fold molar excess of insert, which was the digested pGEM-T-splice variants. In the reaction was added $10 \mu 1$ of $2 x$ Quick Ligation Buffer, $1 \mu 1$ of Quick T4 DNA Ligase and water to the final volume of $20 \mu 1$. The samples were mixed, and submitted to a bench top centrifuge. Incubation at room temperature $\left(25^{\circ} \mathrm{C}\right)$ for 5 minutes was performed. Immediately after 
the 5 minutes the samples were chilled on ice and then transformed in DH5 $\alpha$ cells. All the sequences, including the PCR amplified splice variants were verified by sequencing.

The E65 construct was cloned into a pcDNA3-Venus, which encodes an E65 fused protein with Venus at its C-terminus. HEK293-Eag1 cells transfected with pcDNA3-E65Venus were plated in uncoated $12 \mathrm{~mm}$ round \#1 glass coverslips in 24well plates at a density of $\sim 10,000$ cells per well. After $48 \mathrm{~h}$ in culture, cells were fixed for $10 \mathrm{~min}$ at room temperature $\left(25^{\circ} \mathrm{C}\right)$ with $4 \%$ paraformaldehyde in $\mathrm{PBS}$, washed three times with PBS, and then permeabilized with $0,3 \%$ Triton X-100 in PBS. Subsequently, the detergent was removed and the coverslips were washed. Before mounting, cells were loaded with TOPRO, a nucleic acid dye, at 100ng/ml in PBS for 10 min. Coverslips were mounted onto 3 inch x 1 inch x $1 \mathrm{~mm}$ slides (Fisher Scientific) using Prolong Gold (Inivitrogen).

\subsection{Confocal Microscopy}

Three-dimensional (3D) confocal images were acquired with a Zeiss LSM 510 Meta mounted on a Axiovert 200 M Zeiss inverted microscope controlled by LSM Image Browser Rel. 4.2 Zeiss software. Images stacks were acquired with $0.53 \mu \mathrm{m}$ steps throughout the depth of the cells for both YFP (excitations, 514; emission, 526612) and TOPRO (excitations, 633; emission, 644-719). Image stacks were converted to a series of 16-bit TIF files and imported into Imaris $^{(\mathrm{R})}$ x64 6.2.1 (Bitplane Scientific Solutions) in which image volume measurements were made based on pixel intensity in the $\mathrm{x}-\mathrm{y}$ plane throughout the $\mathrm{z}$ depth of the stack. 


\subsection{Real Time PCR}

Real-time PCR was performed using the TaqMan system in a LightCycler 480 (Roche Applied Science). The oligonucleotides used were (5'-3'): Forw.: TCTGTCCTGTTTGCCATATGATGT, FAMAACGTGGTTGAGGGCATCAGCAGCCT(-Tamra) and Reverse: CGGAGCAGCCGGACAA. Transferrin receptor was used to control for RNA integrity, with the following oligonucleotides: GACTTTGGATCGGTTGGTGC, CCAAGAACCGCTTTATCCAGAT, and JOE-TGAATGGCTAGAGGGA-TAMRAdTACCTTTCGTCCC (probe).

PCR conditions were: $2 \min 50^{\circ} \mathrm{C} ; 15 \mathrm{~min} 94^{\circ} \mathrm{C} ; 15 \mathrm{~s} 94^{\circ} \mathrm{C} ; 15 \mathrm{~s} 56^{\circ} \mathrm{C}$; and $1 \mathrm{~min}$ $60^{\circ} \mathrm{C}$ (40 cycles). Copy numbers per volume of the samples were determined with the help of a calibrator curve of plasmid standards with a known number of copies. The resulting concentrations were standardized to the amount of a housekeeping gene, the human transferrin receptor type 1 . The plotted graphs are thus standardized values further normalized to the Control with means and S.E. Data shown in the figures correspond to the analysis of results obtained in three independent RNA preparations.

\subsection{PCR}

The primers used for Eag1 and their expected amplicon size are described in table 1. The primers used in the nested PCR were: External Forward: 5'-TGT TCG GCG GTC CAA TGA TAC TAA-3'; External Reverse: 5'-GGT CCC GGC CCC CTC TC-3'; Internal Forward: 5'-TGT TGG GGA ATG CTC AGA TAG TGG-3'; Internal 
Reverse: 5'-GGG GGC CTC ATT CTT TCG TTT CAT-3'.

PCR was performed using $2 \mu \mathrm{L}$ first strand cDNA in a $50 \mu \mathrm{L}$ reaction volume containing 1X Taq Polimerase Buffer (New England BioLabs), $1.5 \mathrm{mM} \mathrm{MgCl} 2,10 \mathrm{mM}$ of each deoxynucleotides (dNTPs), 1U Taq Polymerase (New England BioLabs), and 40 pmol of each specific primer (Table 1). For the second round of the nested PCR we used as DNA sample $1 \mu \mathrm{L}$ from the first round. The first round of the Nested PCR was performed for 20 times, and the second round 35 times. The samples were submitted to this program in the thermocycler: 3 minutes at $95^{\circ} \mathrm{C}, 30$ seconds at $95^{\circ} \mathrm{C}, 30$ seconds at $59^{\circ} \mathrm{C}$ and 3 minutes at $72^{\circ} \mathrm{C}$. After this reaction, the samples were analyzed by $1.5 \%$ agarose gel.

\section{7 $\quad$ SiRNA transfections}

We used a siRNA designed to target the Eag1 sequence (Target sequence: 5'TACAGCCATCTTGGTCCCTTA-3') using the HiPerformance siRNA Design Algorithm. siRNA's (30 $\mathrm{nM})$ were transfected using DreamFect (Oz Biosciences) in OptiMEM medium (Invitrogen). The siRNA transfections were performed using $15 \mu \mathrm{l}$ of DreamFect transfection reagent plus $185 \mu 1$ of OptiMen medium without serum (Gibco). This mixing was called tube 1, and it was incubated at room temperature for 10 minutes. In a tube $2,7.5 \mu 1$ of $20 \mu \mathrm{M}$ siRNA stock solution was mixed with OptiMen to a final volume of $200 \mu \mathrm{l}$. After the 10 minutes incubation, the $200 \mu 1$ of tube 1 was added directly inside the solution in tube 2. The mixing was incubated at room temperature for 20 minutes. The $400 \mu \mathrm{l}$ was added directly in a $4.6 \mathrm{ml}$ normal 
supplemented medium T25 $\left(25 \mathrm{~cm}^{2}\right)$ cell culture bottle and wait 48 hours.

After DreamFect transfection, cells were not suited for eletrophysiological experiments. Therefore we used Amaxa Nucleofector Kit and device (Lonza). Cells were plated two days before transfection. The $2.25 \mathrm{ml}$ of Nucleofector Solution L was supplemented with $0.5 \mathrm{ml}$ of Supplement. The cells were harvest with trypsin/EDTA and the trypsinization was stopped by medium addition. The cells were counted to determine the cell density and they were centrifuged. The pellet was resuspended in Nucleofector Solution L, supplemented, to a final concentration of $1 \times 10^{6}$ cells $/ 100 \mu 1$. In $100 \mu 1$ of cell suspension $1 \mu 1$ of Eag1 siRNA, stock solution at $3 \mu \mathrm{M}$, was added. The cell suspension was transferred into an amaxa electroporation cuvette. The cuvette was placed in the Nucleofector device and for IPC298 cells the program selected was T020, and for IGR39 cells, T030. After the procedure the cells were removed from the cuvette immediately and $500 \mu 1$ of the pre-warmed culture medium was added. Subsequently, the cells were plated into T025 cell culture bottles containing $4.5 \mathrm{ml}$ fresh supplemented cell culture medium.

The negative control we used a siRNA with the reverse but not complementary ("scrambled") sequence of Eag1. The molecules have the same composition and closest structure to the active siRNA. The sense strand of the annealed siRNA duplexes was modified with two dT at the 3'-ends, the antisense strand with the sequence corresponding desoxynucleotides to stabilize the siRNAs against degradation. All the siRNA were synthesized by Qiagen. The cells were incubated with the siRNA and the transfection reagent, when used, for between $6 \mathrm{~h}$ and $8 \mathrm{~h}$. Cells were harvested for the experiments 24 hours after the start of the transfection for real-time experiments, and 48 hours for patch-clamp experiments. 


\subsection{Xenopus oocytes preparation}

Xenopus oocytes were prepared as described previously (Almouzni and Wolffe, 1993). Stage VI oocytes were sorted and used within $24 \mathrm{~h}$ of oocyte preparation. Oocytes were maintained at $18^{\circ} \mathrm{C}$ in $\mathrm{ND} 96$ medium (mM: $96 \mathrm{NaCl}, 2 \mathrm{KCl}, 0.2 \mathrm{CaCl}$, $2 \mathrm{MgCl} 2,0.5$ teophylline, 5 HEPES, $\mathrm{pH} 7.5$ ). The injection was performed with $50 \mathrm{~nL}$ for each cRNA solution. After injection, only oocytes with homogenous pigmentation and normal turgor were collected. The experiments were performed after $48 \mathrm{~h}$.

After linearization with SfiI, cRNA was prepared in vitro using the T7 promoter containing in the pSGEM vector, with the T7 mMessage mMachine Kit (Ambion). Oocytes were injected with 0.025 - 1ng cRNA and kept at $18^{\circ} \mathrm{C}$ in ND96 solution (96 $\mathrm{mM} \mathrm{NaCl}, 2 \mathrm{mM} \mathrm{KCl}, 0.2 \mathrm{mM} \mathrm{CaCl} 2,2 \mathrm{mM} \mathrm{MgCl}_{2}, 0.5 \mathrm{mM}$ teophilline, $5 \mathrm{mM}$ HEPES, pH 7.5).

\subsection{Protein extraction, separation and western blot}

To obtain cell lysates, cultures were washed twice with phosphate-buffered saline and resuspended in $3 \mathrm{ml}$ of lysis buffer (mM: 50 Tris- $\mathrm{HCl} \mathrm{pH}$ 7.4, $300 \mathrm{NaCl}, 5$ EDTA, 1\% Triton x-100 containing protease inhibitor cocktail (Roche)). After 30 minutes of incubation, cells were centrifuged for $15 \mathrm{~min}$ at $14.000 \mathrm{rpm}$ and the supernatant was used as total cell extract.

Protein concentration was determined using BCA (bicinchoninic acid) Protein Assay Reagent (from Pierce) that employs BSA (albumin) as a pattern curve. The samples (triplicate) in a protein solution of $10 \mu 1$ were incubated for 30 minutes at $37^{\circ} \mathrm{C}$ 
together with BCA reagent, composed by solution A (sodium carbonate, sodium bicarbonate, bicinchoninic acid and sodium tartrate in $0.1 \mathrm{M}$ sodium hydroxide) and solution B (4\% cupric sulfate) in a proportion of $8 \mathrm{ml}$ solution A to $160 \mu 1$ solution B.

Immunoprecipitation was performed using Protein G Magnetic Beads from New England BioLabs. An extract containing $1 \mathrm{mg}$ protein was first pre-incubated for 1 hour, at $4{ }^{\circ} \mathrm{C}$, with $50 \mu 1$ of magnetic beads to pre-clear the crude cell extract and avoid non-specific binding to the beads. A magnetic field was applied to the mixture for 30 seconds and the beads were pulled to the side of the tube. The supernatant was placed in a clean tube and the beads were discarded. $2 \mu \mathrm{g}$ of an anti-Eag1 monoclonal antibody (33) were applied to the supernatant, and the mixture was incubated for 1 hour at $4{ }^{\circ} \mathrm{C}$. After this, $50 \mu 1$ of magnetic beads were applied to the suspension, vortexed and incubated for 1 hour at $4^{\circ} \mathrm{C}$. The beads were recovered in a magnetic field, washed 3 times with protease free wash solution $(0.1 \%$ Triton, $50 \mathrm{mM}$ TRIS-Cl, $300 \mathrm{mM} \mathrm{NaCl}$, $5 \mathrm{mM}$ EDTA plus 1 protease inhibitor tablet $/ 10 \mathrm{ml})$. Then the beads were resuspended in 16.25 $\mu 1$ TBS (TRIS Buffered Saline: 50mM TRIS and 150mM NaCl, $\mathrm{pH} 7.6$ ), $2.5 \mu 1$ of reducer buffer (Invitrogen) and $6.25 \mu 1$ of LDS sample buffer (Invitrogen). The samples were incubated for 10 minutes at $70^{\circ} \mathrm{C}$ and then exposed to a magnetic field to separate beads from supernatant.

To obtain the oocyte lysates, 15 oocytes were resuspended in $300 \mu \mathrm{L}(20 \mu \mathrm{L}$ per oocyte) of oocytes lysis buffer $(1 \%$ Triton, $150 \mathrm{mM} \mathrm{NaCl}, 20 \mathrm{mM}$ Tris- $\mathrm{HCl}, 5 \mathrm{mM}$ $\mathrm{MgCl}, 5 \mathrm{mM}$ EDTA). After 30 minutes incubation, oocytes were centrifuged 2 times for 2 min at 14,000rpm and the supernatant was used as total cell extract. The Eag1 immunoprecipitation process was the same as the one used for cultivated cell extracts. The same process was also used when the antibody was the mouse monoclonal anti- 
Xenopus cyclin B2 (Santa Cruz Biotechnology X121.10). The immunoprecipitation was performed using $2 \mu \mathrm{g}$ of anti-cyclin B2, and for western-blot the $20 \mu 1$ of antibody were diluted in $10 \mathrm{ml}$ of TBS-T (Tris-buffered saline $+0.05 \%$ Tween 20 ).

The supernatant was separated by gradient SDS-PAGE NuPAGE Novex TRISAcetate 3-8\% gel (Invitrogen) and transferred to nitrocellulose membranes. Membranes were blocked for 1 hour with $0.1 \%$ casein (Roche Applied Science), incubated with polyclonal anti-Eag1 antibody in $0.1 \%$ casein for 1 hour, washed with deionized water for 7 times and then incubated in TBS-T (Tris-buffered saline $+0.05 \%$ Tween 20 ) for 5 min. Following, the membranes were incubated with peroxidase-coupled anti-rabbit antibody (Amersham Biosciences) for 1 hour. The membranes were developed using Millipore Immobilon system. To prepare working horseradish peroxidase (HRP) substrate $5 \mathrm{ml}$ from each Luminol Reagent and Peroxide Solution were mixed. Signals were detected in a Bio-Rad Chem-Doc luminescence detection system.

\subsection{Electrophysiology}

\subsubsection{Patch-Clamp}

IPC298 and IGR-39 cells were plated on poly-L-lysine-coated glass coverslips in Petri dishes and allowed to attach overnight. Cells were left untreated or treated with siRNA for $6 \mathrm{~h}$. After 24, 30 or 48 h., the coverslips were removed from the dish and used for electrophysiology measurements.

Electrophysiological recordings were performed in the whole-cell configuration of the patch-clamp, using an EPC9 amplifier and Pulse software (HEKA, Germany). 
Currents were filtered at $10 \mathrm{kHz}$ and digitized at $50 \mathrm{kHz}$. Patch pipettes were pulled from Corning \#0010 glass (World Precision Instruments) to resistances of 1-2 $\mathrm{M} \Omega$. Solutions for IPC298 and IGR-39 cells contained (mM) Internal: $100 \mathrm{KCl}, 45$ NMDG, 5 1,1-bis(O-aminophenoxy)ethane-N,N,N,N-tetracetic acid (BAPTA), 5 EGTA, 1 $\mathrm{MgCl}_{2}, 10$ HEPES pH 7.4; External: $160 \mathrm{NaCl}, 2.5 \mathrm{KCl}, 2 \mathrm{CaCl}_{2}, 1 \mathrm{MgCl}_{2}, 8$ Glucose, 10 HEPES pH 7.4.

We used the automated capacity compensation of the amplifier to estimate series resistance, which was compensated to $85 \%$, and cell capacity. A P/N leak subtraction protocol was performed (at $-120 \mathrm{mV}$ ). To determine Eag1 current amplitude, we applied a conditioning pulse to $-100 \mathrm{mV}$ for $1500 \mathrm{~ms}$ to slow down the activation of Eag1, and the outward currents were then elicited by a square depolarization to $+40 \mathrm{mV}$ for $500 \mathrm{~ms}$.

\subsubsection{Two - electrode voltage-clamp}

Two-electrode voltage-clamp recordings were performed 1-3 days after c-RNA injection, using a Turbo TEC-10CD amplifier (NPI electronics) at room temperature. The intracellular electrodes had resistances of 0.3-1.5 $\mathrm{M} \Omega$ when filled with $2 \mathrm{M} \mathrm{KCl}$. The extracellular measuring solution (Normal Frog Ringer, NFR) contained (mM): 115 $\mathrm{NaCl}, 2.5 \mathrm{KCl}, 1.8 \mathrm{CaCl}_{2}, 10 \mathrm{HEPES} / \mathrm{NaOH}, \mathrm{pH} 7.2$, with or without $5 \mathrm{mM} \mathrm{MgCl}$.

Data acquisition and analysis were performed with the Pulse-Pulse Fit (HEKA Electronics) and IgorPro (Wave-Metrics) software packages. Currents records were filtered at $1 \mathrm{kHz}$. The cells were held at $-100 \mathrm{mV}$ membrane potential. The applied voltage protocols are described in the figure legends. A leak protocol was applied at 
$120 \mathrm{mV}$ in the I-V protocols.

\subsection{Northern-Blot}

The mRNA from the cell lines were analyzed in a $2 \%$ formaldehyde agarose gel for 7 hours. The running buffer was 1x MOPS (80ml DEPC-water, $4.18 \mathrm{~g} 3 \mathrm{~N}$ Morpholina propane sulfonic acid (MOPS), at this time the $\mathrm{pH}$ was adjusted to 7.0 with $\mathrm{NaOH} ; 1,66 \mathrm{ml} 3 \mathrm{M}$ sodium acetate, $2 \mathrm{ml} 0.5 \mathrm{M}$ EDTA, the volume was adjusted to 1 liter with DEPC-water, the solution was kept protected from light at $4^{\circ} \mathrm{C}$ ).

The transfer process to a Hybond $\mathrm{N}$ membrane was performed following the next steps:

- the gel was washed twice with DEPC-water for 10 minutes, and then twice with $2 \mathrm{x}$ SSC Buffer (0.3M NaCl, 0.03M Sodium-Citrate, $\mathrm{pH}$ 7.0) for 10 minutes;

- the Hybond N membrane was equilibrated in 2x SSC for 5 minutes;

- a Whatman paper bridge was cut in the gel size. The platform of the gel box was covered with the bridge in a way that there was still a piece of the bridge in each of the wells. The wells were filled with 20x SSC;

- a Whatman paper piece, larger than the membrane wet in 2x SSC, was placed above the base of the bridge;

- the gel was placed above the Whatman paper layer, and all air bubbles were removed;

- the membrane was placed on top of the gel. Again, all air bubbles were removed;

- 3 Whatman paper piece, larger than the membrane wet in $2 \mathrm{x} \mathrm{SSC}$, was placed on top of the membrane; 
- then, 40 dry Whatman paper pieces, larger than the membrane, on top of the sandwich;

- lastly, a heavy object was placed on top of the papers layers. The transfer was left to happen overnight.

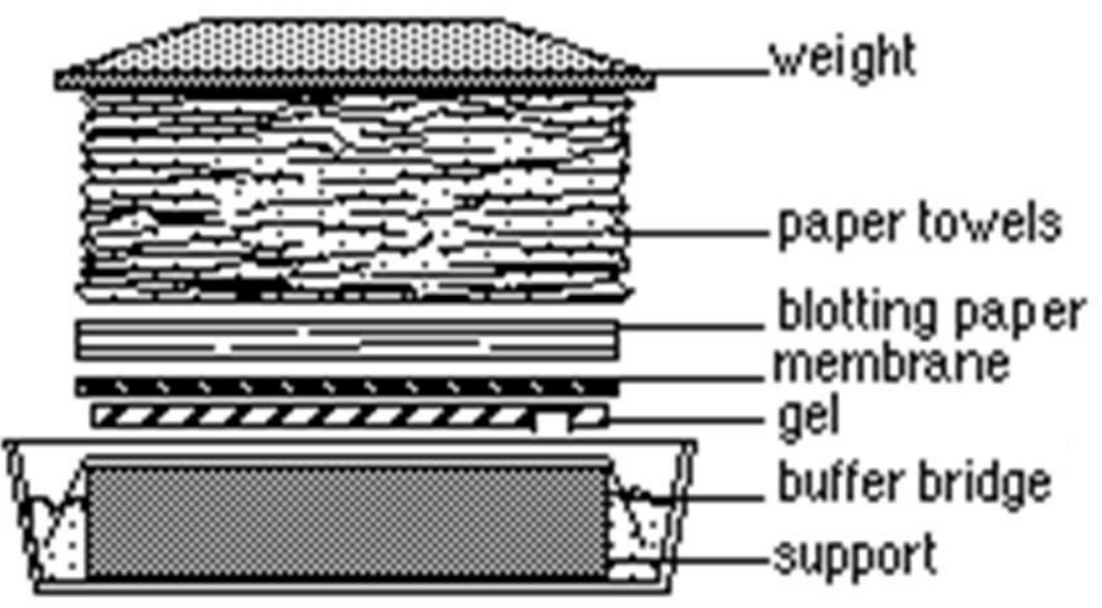

Figure 3.3 Northern-blot membrane transference. The scheme shows how the sandwich to transfer a northern blot membrane was prepared. Adapted from http://www.currentprotocols.com/protocol/txa03e.

The RNA was transferred to a Hybond $\mathrm{N}$ membrane overnight and crosslinked (UV Stratalinker 1800- Stratagene) by applying energy of 1200 Joule. Then the membrane was left to dry for one day. Before starting the hybridization, the membrane was washed with $2 \mathrm{x}$ SSC for 10 minutes, and a pre-hybridization process was done with $8 \mathrm{ml}$ of Rapid-hybr-Buffer (Roche) for 2-3 hours. Afterwards, the membrane was incubated overnight in $10 \mathrm{ml}$ of Rapid-hybr-Buffer plus a probe specific for the Cterminus of the Eag1 channel $\left[{ }^{32} \mathrm{P}\right] \mathrm{dCTP}-$ labelled Eag1 700 bp fragment, overnight at 
$65^{\circ} \mathrm{C}$

The labeling process was performed by following the instructions from Deca Label DNA Labeling Kit from Fermentas: 100 ng of DNA template was mixed together with $10 \mu 1$ of Decanucleotide in $5 x$ Buffer and nuclease-free water to $40 \mu 1$ in a $1.5 \mathrm{ml}$ microcentrifuge tube. The tube was vortexed and spun down for 3-5 seconds. Then, incubated in a boiling water bath for 10 minutes and cooled on ice. After this, a quick spin down was done. Subsequently, $3 \mu 1$ of Mix $C$ was added in the reaction tube, $6 \mu 1$ of $\left[\alpha{ }^{32} \mathrm{P}\right]-\mathrm{dCTP}$ and $1 \mu 1$ of Klenow fragment $(5 \mathrm{u})$. The tube was vortexed, spun down for 3-5 seconds and incubated at $37^{\circ} \mathrm{C}$ for 5 minutes. The reaction was stopped by addition of $1 \mu 10.5 \mathrm{M}$ EDTA, $\mathrm{pH}$ 8.0. Afterwards, a removal of the unincorporated nucleotides was performed using Illustra MicroSpin G-50 Columns (GE). The column preparation was performed resuspending the resin inside and breaking the cap below the column, and then a centrifugation was performed for 1 minute at $735 \mathrm{xg}$. After the centrifugation a fresh tube was placed in the column and $12-50 \mu 1$ of the sample was applied directly inside the column. A centrifugation was performed for 2 minutes at $735 \mathrm{x} \mathrm{g}$ for removal of unlabeled nucleotides from DNA. The labeled probe was used directly for hybridization with the membrane.

After overnight hybridization the membrane was collected and washed twice with $50 \mathrm{ml}$ of $2 \mathrm{x} \mathrm{SSC}$, for 30 minutes. Then washed again twice with $2 \mathrm{x} \mathrm{SSC}+0.1 \%$ SDS, for 30 minutes. The wash steps were performed at $65^{\circ} \mathrm{C}$. The membrane was then exposed for 4 hours or overnight. The membrane was also exposed to a phosphoimager plate (Fuji) for 2 hours and subsequently read. 


\subsection{Statistical analysis}

The statistical analysis was performed using the program GraphPad Prism v4.0.

The $\mathrm{t}$ test nonparametric, Mann Whitney, was used for comparisons between each treatment and its control. Real-time experiments were evaluated according to Pfaffl test (Pfaffl et al., 2002). 


\section{$4 \quad$ Results}

\subsection{Functional Characterization of Eag1 in Melanoma Cells}

\subsubsection{Both, IPC298 and IGR39 express Eag1 RNA and protein}

Previous experiments indicated that these melanoma cells were positive for Eag1, in contrast to published data. The first strategy was to test whether we could detect Eag1 amplification by a RT-PCR. To perform these experiments we used different pairs of primers, located in various parts of the Eag1 sequence, in an attempt to verify whether or not mutations, deletions or splice variants occurred in the sequence in these melanoma cells.

Our first interpretation of this discrepancy was that the primers used were different, and we hypothesized a different splice variant in IGR39 cells. Cancer cells are in an abnormal cell state associated with an increased rate of heritable genomic alterations as chromosomal rearrangements, deletions and inversions. This genetic instability could generate also splice variants of the same gene or many mutations. The used primers were located mainly in the exon junctions to verify if the junctions in 
Eag1 sequence were preserved. As seen in Figure 4.1, we could detect amplification in all combinations, indicating that the full length Eag1 is present in these cell lines. As a positive control we used HEK293 cells transfected with Eag1a, and another melanoma cell line, IPC298.

\begin{tabular}{|c|c|c|c|}
\hline Eag1 target & Primer name & Size & Sequence \\
\hline $\begin{array}{l}\text { exon1-2 } \\
\text { junction }\end{array}$ & 1-forward & $255 \mathrm{bp}$ & $\begin{array}{l}\text { 5'-GCG GTC CAA TGA TAC TAA TTT TGT } \\
\text { GTT-3' }\end{array}$ \\
\hline $\begin{array}{l}\text { exon } 3-4 \\
\text { junction }\end{array}$ & 1-reverse & & $\begin{array}{l}\text { 5'-CCA CAC AGG TGT CCT GTT CTT CTT } \\
\text { GTA C-3' }\end{array}$ \\
\hline $\begin{array}{l}\text { exon } 4-5 \\
\text { juntion }\end{array}$ & 2-forward & $540 \mathrm{bp}$ & $\begin{array}{l}\text { 5'-GAT GATTCA TGT AAA GGC TGG GGG } \\
\text { AAG-3' }\end{array}$ \\
\hline $\begin{array}{l}\text { exon } 6 a-7 \\
\text { junction }\end{array}$ & 2-reverse & & $\begin{array}{c}\text { 5'-GCT GAA CAG GCT GCT GAT GCC CTC } \\
\text { ATC CAC GTT CTC-3' }\end{array}$ \\
\hline exon7 & 3-forward & $864 \mathrm{bp}$ & 5'-CTA AAA GTT GTC CGG CTG CTC C-3' \\
\hline $\begin{array}{l}\text { exon 9-10 } \\
\text { junction }\end{array}$ & 3-reverse & & 5'-CTT TTC CTA GAA TGG CCA CCA C-3' \\
\hline exon 9 & 4-forward & $450 \mathrm{bp}$ & 5'-GTT CCA GAC GGT GCA CTG TG-3' \\
\hline exon 11 & 4-reverse & & 5'-CTG TCG GAA TCT CTG GAA GAG G-3' \\
\hline exon 11 & 5-forward & $450 \mathrm{bp}$ & 5'-GAT CAG CGA TGT GAA ACG TGA A-3' \\
\hline exon 11 & 5-reverse & & 5'- CAT CGA CTC AGC CTT GGA CAC-3' \\
\hline exon 11 & 6-forward & $450 \mathrm{bp}$ & 5'-TCA AAG ATG CTT GCG GGA AGA-3' \\
\hline exon 11 (end) & 6-reverse & & 5'-CAG CTG GCT CCA AAA ATG TCT-3' \\
\hline exon 11 & 7-forward & $450 \mathrm{bp}$ & 5'-GAT GGA GAC ACT TCC CGA GAG G-3' \\
\hline $\begin{array}{c}\text { pos- } \\
\text { transcriptional } \\
\text { exon } 11\end{array}$ & 7-reverse & & 5'-GGT GAC GGC AGG GTT GGA-3' \\
\hline
\end{tabular}

Table 2 Primer sequences and their respective sizes and targets. 


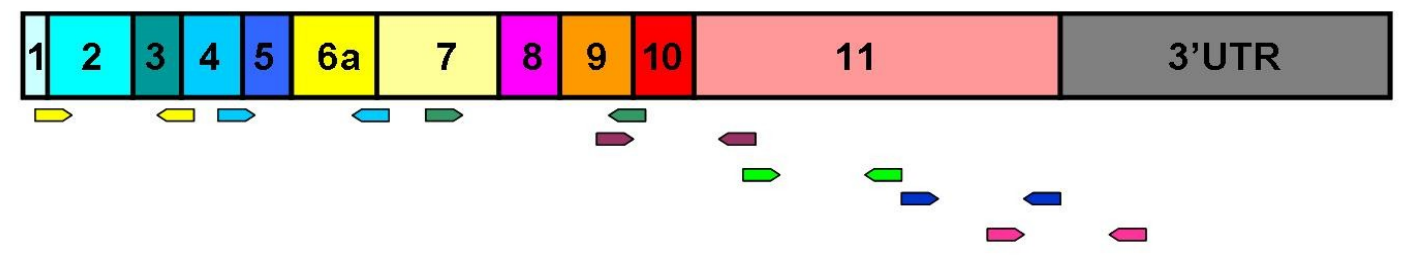

IPC298

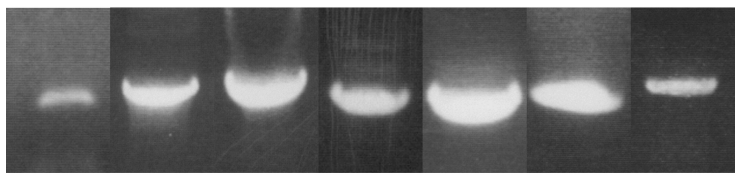

IGR38

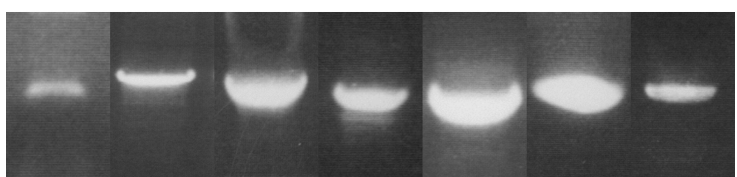

HEK293-hEag1

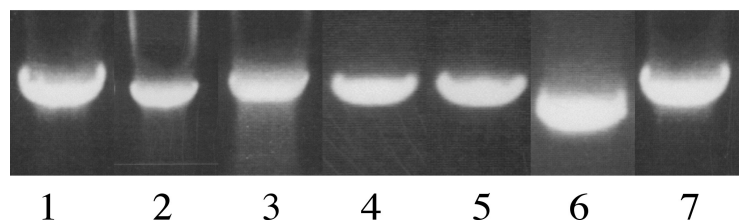

Figure 4.1 hEag1 expression by RT-PCR. Amplification of different sequences of Eag1 in IPC298, IGR39 and HEK293-Eag1 transfected cells. The numbers are referent for each used primers described on Table 1. The scheme above represents the Eag1 sequence, the exons are identified by number and the arrows represent the localization of the primers from Table 2.

The fact that cells possess RNA coding for Eag1 does not necessarily mean that there is expression of the protein. To test this, we used western-blot. The low abundance of the channel in a native expressing system makes it difficult to detect the protein from crude extract. To solve this problem, we performed an immunoprecipitation in both melanoma cell lines and in the HEK293-Eag1 control cell 
line (Figure 4.2). The immunoprecipitation was achieved using a monoclonal antibody against the C-terminus of the Eag1 channel (mAb 33) and the western-blot was performed with a polyclonal antibody (9391). The use of two antibodies also increases the specificity of the immunoblot, since a positive signal requires recognition by both antibodies.

IGR39

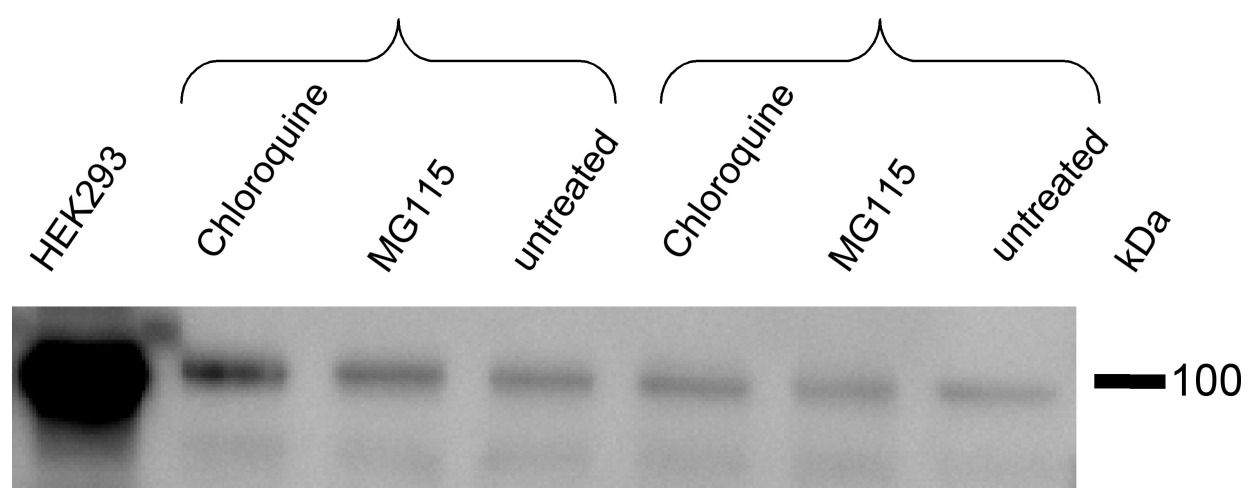

Figure 4.2 Immunoprecipitation of Eag1 in melanoma cell lines. Cell extracts precipitated with an anti-Eag1 monoclonal antibody and detected with an anti-Eag1 polyclonal antibody.

To enrich the protein we inhibited proteolysis by addition of $10 \mu \mathrm{M}$ of MG115 and $100 \mu \mathrm{M}$ of chloroquine. MG115 is a potent inhibitor of the $20 \mathrm{~S}$ subunit of the proteasome, and chloroquine is an endosomal acidification inhibitor, they are very useful to detect low levels of protein in native system.

The semi-quantitative analysis of the Eag1 signal intensity showed similar levels in both melanoma cell lines under control conditions. However, when the cells were treated with chloroquine the difference was more significant, IPC298 express less 
than IGR39. In the transfected control HEK293-Eag1 we see the high level of Eag1 protein expression.

Based in these results we conclude that both melanoma cell lines express Eag1 and protease inhibition increases the protein level in both cell lines, specially using chloroquine.

\subsubsection{Ion currents in melanoma cell lines}

The experiment described above indicates that Eag1 is expressed at both the RNA and protein level in IGR39 cells. The next test was to investigate the functional expression of this protein in these melanoma cells using whole-cell patch-clamp recordings.

Figure 4.3 shows representative traces from IPC298 (A), HEK293-Eag1 (B) and IGR39 (C). In IPC298 melanoma cells (A), depolarization induced a slowly activation, non-inactivating outward current with kinetics compatible with Eag1. For comparison, panel (B) shows the traces obtained from HEK293-Eag1 transfected cells. In contrast, IGR39 cells (C) showed a current with fast activation and a certain degree of inactivation. 

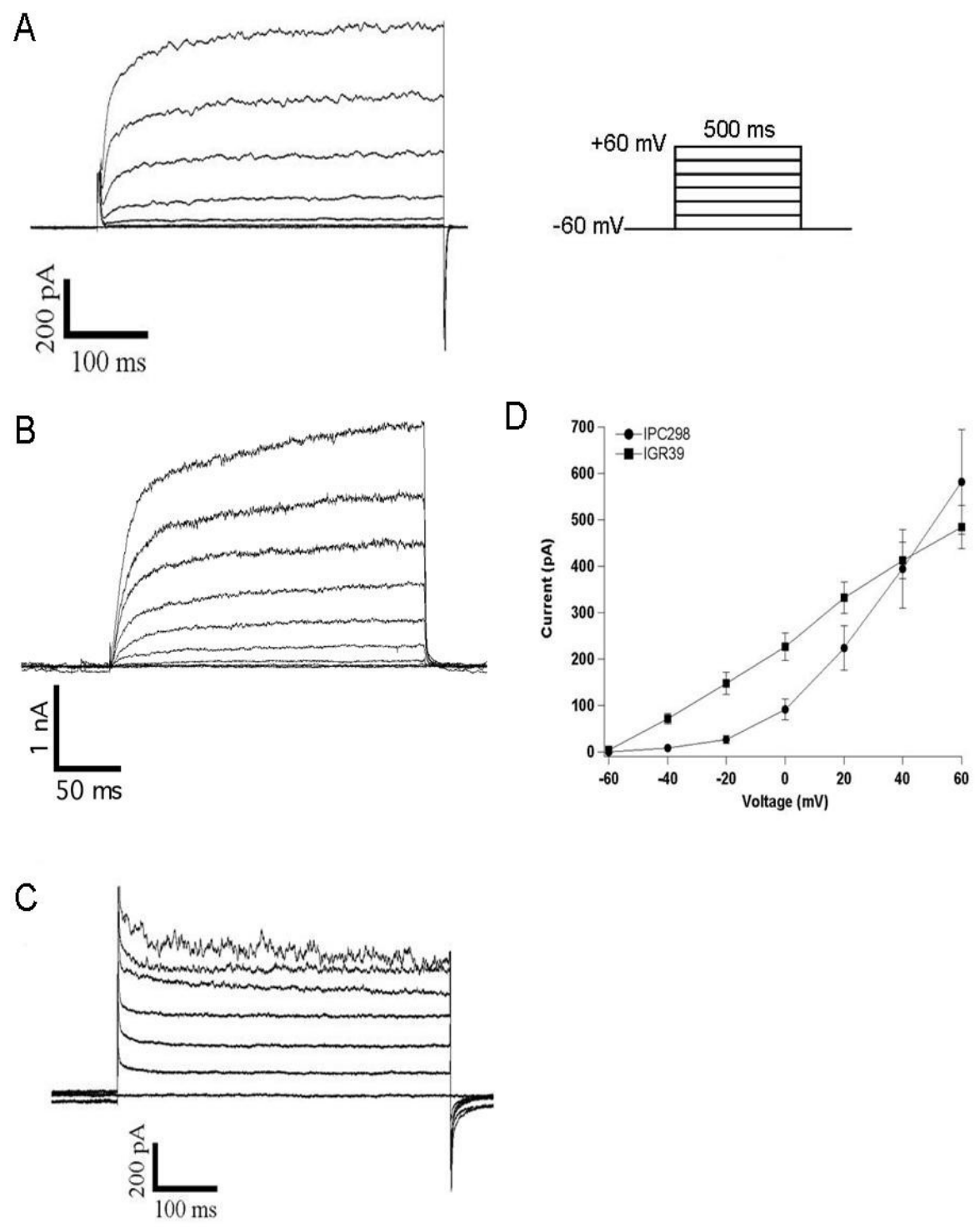

Figure 4.3 Currents expressed by melanoma cell lines in presence of $1 \mathbf{m M ~} \mathrm{Mg}^{+2}$. IV relationships were determined by measuring the whole-cell current elicited by depolarizations to a test potential from a holding potential of $-60 \mathrm{mV}$ to $+60 \mathrm{mV}$ for $500 \mathrm{~ms}$ in $20 \mathrm{mV}$ increments. In (A) the current elicited by IPC298 and by HEK293Eag1 transfected cells (B). The current elicited by IGR39 cells is represented in (C). (D) represents the mean $( \pm$ SEM) of the current amplitude $v s$ membrane potential obtained from IPC298 $(\mathrm{n}=82)$ and IGR39 ( $\mathrm{n}=121)$ cells. 
The hallmark of Eag currents is a strong dependence of activation kinetics on holding potential, such that the activation is slower the more negative the prepulse potential (Cole-Moore shift). This effect is exacerbated by $\mathrm{Mg}^{+2}$ in the extracellular medium.

A very marked effect reminiscent of the Cole-Moore shift described for other $\mathrm{K}^{+}$ channels was detect. Typical traces are shown in Figure 4.4 IPC298 (A) and IGR39 (B) cells. IPC298 cells showed the typical behavior of Eag1 currents, while IGR39 showed no deceleration of activation. Moreover, in IGR39 cell the pulse starting from $-120 \mathrm{mV}$ elicited higher currents than the one starting from $-60 \mathrm{mV}$, a phenomenon compatible with recovery from inactivation of an inactivating channel. Together, these experiments allow us to conclude that IGR39 cells do not express current with the characteristics of Eag1, while IPC298 do.
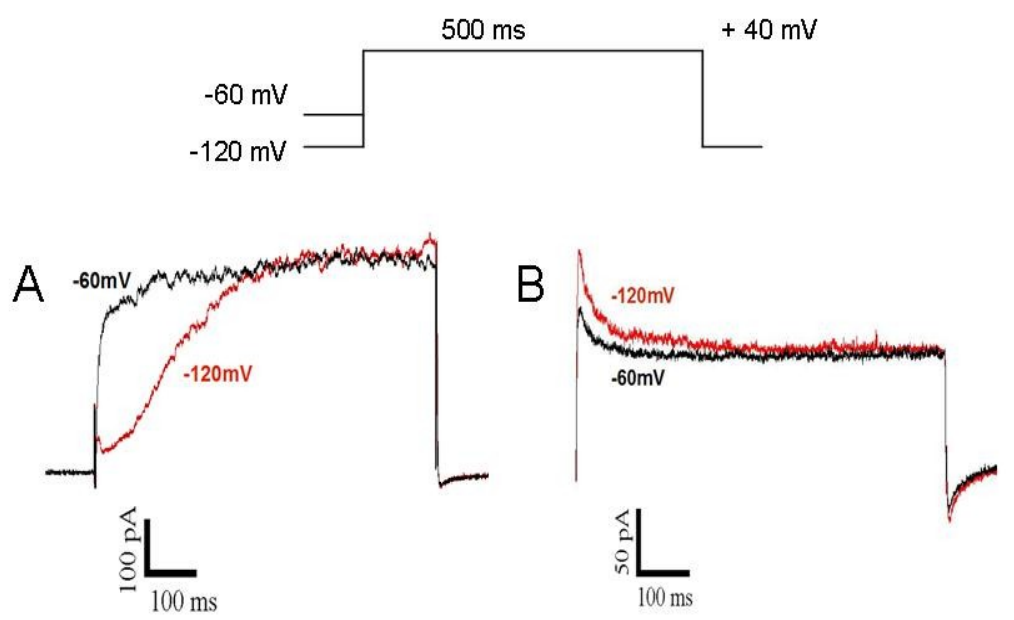

Figure 4.4 Activation kinetics of Eag1 channels in melanoma cell lines. The depicted voltage protocol was applied to the cell lines. The cells were clamped for $6 \mathrm{sec}$ to two different holding voltages ($120 \mathrm{mV}$ and $-60 \mathrm{mV})$ and then depolarized $(+50 \mathrm{mV})$ to activate $\mathrm{K}^{+}$ channels. We see a characteristic shift in IPC298 cell (A) but not in IGR39 cells (B) caused by the dependence of the activation kinetics on the holding voltage. 


\subsubsection{Pharmacology of currents measured in melanoma cell lines}

Gavrilova-Ruch and colleagues (2002) showed that when the tricyclic antidepressant imipramine and the antihistamine astemizole are present in the growth medium of Eag1-expressing melanoma cells, the proliferation is slowed. GarcíaFerreiro (2004) demonstrated that the charged forms of imipramine and astemizole blocks the current through hEag1 $\mathrm{K}^{+}$channels by binding to sites in the intracellular portion of the permeation pathway only accessible when the channels are open.

To test the sensibility of the melanoma cell currents we used imipramine and astemizole aiming to characterize whether these currents were or not sensible to these drugs used to block the Eag1 $\mathrm{K}^{+}$channel.

The $\mathrm{IC}_{50}$ of imipramine for Eag1 is in the $\mu \mathrm{M}$ range (1 to 30$)$. Although imipramine effect is not selective for Eag1 $\mathrm{K}^{+}$channels, we known from previous data that Eag1 current are the major currents expressed in melanoma cells, together with calcium-activated potassium channels $\left(\mathrm{K}_{\mathrm{ca}}\right)$ (Gavrilova-Ruch et al., 2002). Using the two melanoma cell lines, IPC298 and IGR39 we observed that the blockage induced by imipramine was very similar for both cell types (Figure 4.5 ), around $75 \%$ and $70 \%$ of total current was blocked, respectively. 
A

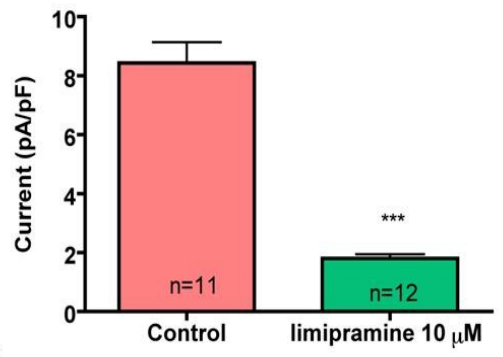

B
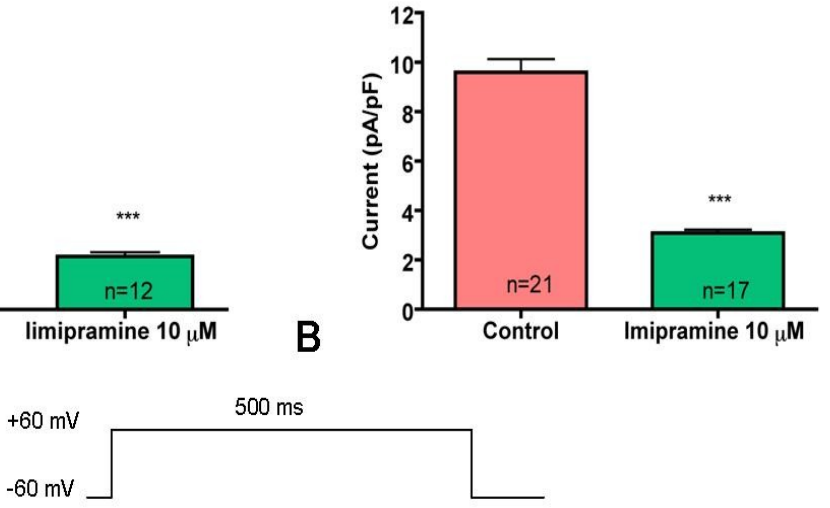

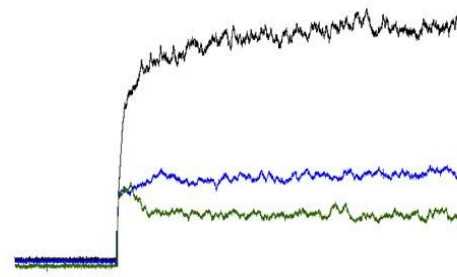

C \&

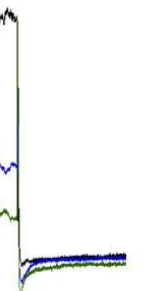

D

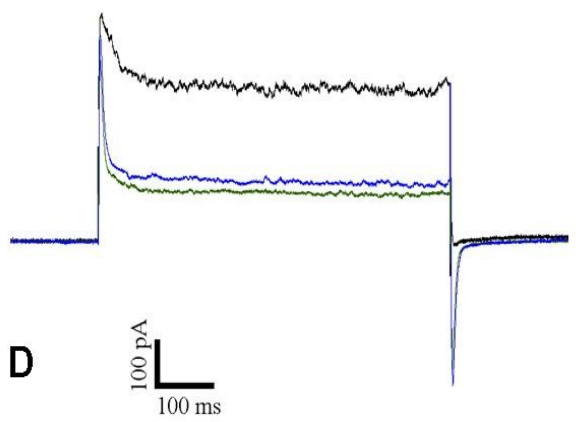

Figure 4.5 Sensitivity of IPC298 and IGR39 melanoma currents to imipramine. Representative traces (A) and (B) showing that more than $70 \%$ of the density current was blocked by imipramine in both cells. (C) and (D) represent the trace currents elicited by the depicted voltage protocol prior to the block (black trace), in the presence of imipramine $10 \mu \mathrm{M}$ (green trace) and after the washout of the drug (blue trace).

In contrast to imipramine, the actions of astemizole on $\mathrm{K}^{+}$channels seem restricted to some members of the eag family. For example, concentrations up to $10 \mu \mathrm{M}$ astemizole have no effect in $\mathrm{K}^{+}$currents in heart, inward rectifier $\mathrm{K}^{+}$channels, and the voltage-gated $\mathrm{K}^{+}$channels Kv1.1 (Suessbrich et al., 1996), Kv2.1 and Kv4.2 (GarcíaFerreiro et al., 2004). To test the effect of astemizole on the melanoma currents we used 
three different concentrations, $500 \mathrm{nM}, 5$ and $10 \mu \mathrm{M}$. When the concentration used was $500 \mathrm{nM}$, the inhibition was around $50 \%$ of the total current in both melanoma cell lines (Data not show). A dose-dependent inhibition of the currents expressed by these melanoma cells was achieved using astemizole; the $5 \mu \mathrm{M}$ inhibition is shown in Figure 4.6.

IPC298

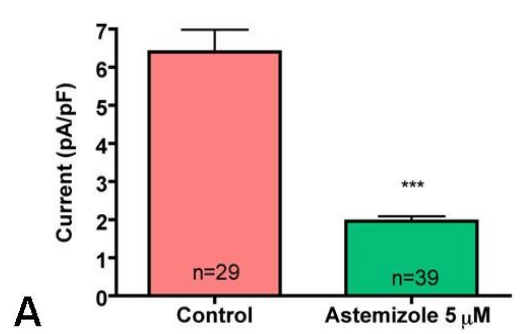

A

$+60 \mathrm{mV}$

$-60 \mathrm{mV}$

IPC298

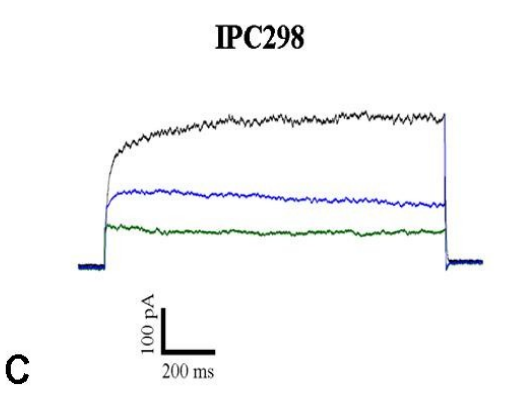

IGR39

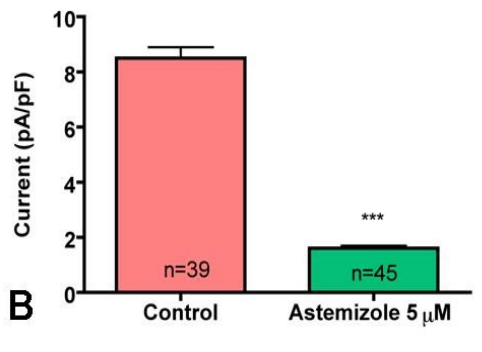

$500 \mathrm{~ms}$

IGR39

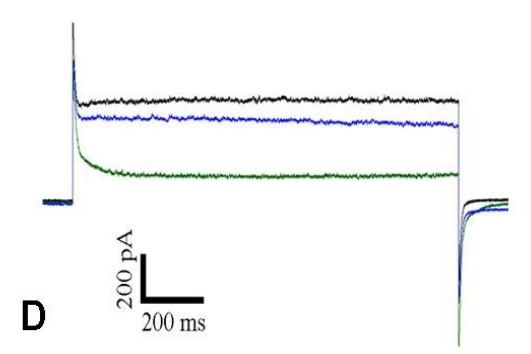

Figure 4.6 Sensitivity of IPC298 and IGR39 melanoma currents to astemizole. Representative traces (A) and (B) showing that approximately $80 \%$ of the current was blocked by $5 \mu \mathrm{M}$ astemizole in both cells. (C) and (D) represent the trace currents elicited by the depicted voltage protocol prior to the block (black trace), in the presence of astemizole (green trace) and after the washout of the drug (blue trace). 
We conclude that, although the electrophysiological features of the current in IGR39 cells do not follow those of Eag1, the pharmacology of the current is compatible with Eag1.

\subsection{4 siRNA reduces Eag1 mRNA and current in melanoma cell lines}

siRNA are 21-23 base pairs double stranded RNA molecules with 2-nucleotide 3'-overhangs (in practice modified to increase stability). When entering the cell, they bind to the RISC complex (RNA-initiated silencing complex), which promotes the cleavage of the RNA containing that particular sequence. The mechanism is very effective, leading to virtual abolition of the expression of the target gene, but it is most interesting feature is the virtually absolute specificity that can be reached (Nature Editorial, 2003).

Weber et al. (2006) show that the use of a short interfering RNA (siRNA) that acts specifically on Eag1 induces a significant decrease in the proliferation of tumor cell lines and reduction of the current in transfected Eag1 cells after 24 hours of transfection.

Since we do not have highly selective drugs that inhibit Eag1, siRNA is a very useful tool to identify these channels. Here we use the same target sequences as Weber and coworkers (2006) at a concentration of 30nM.

As a negative control we used a siRNA with the reverse but not complementary ("scrambled") sequence of the Eag1 (Figure 4.7, scrambled). siRNA specific for the Eag1 sequence was effective in reducing the Eag1 mRNA level in these melanoma cell lines (Figure 4.7). 


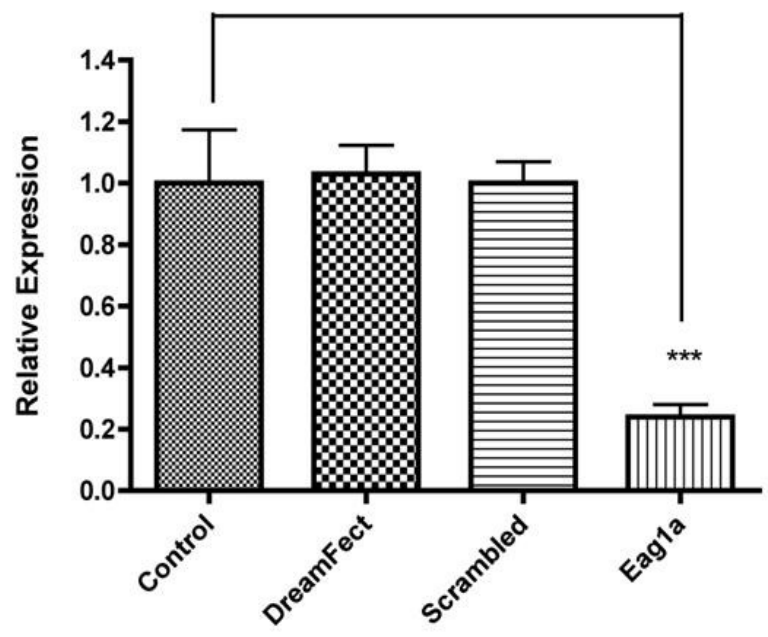

B

IGR39

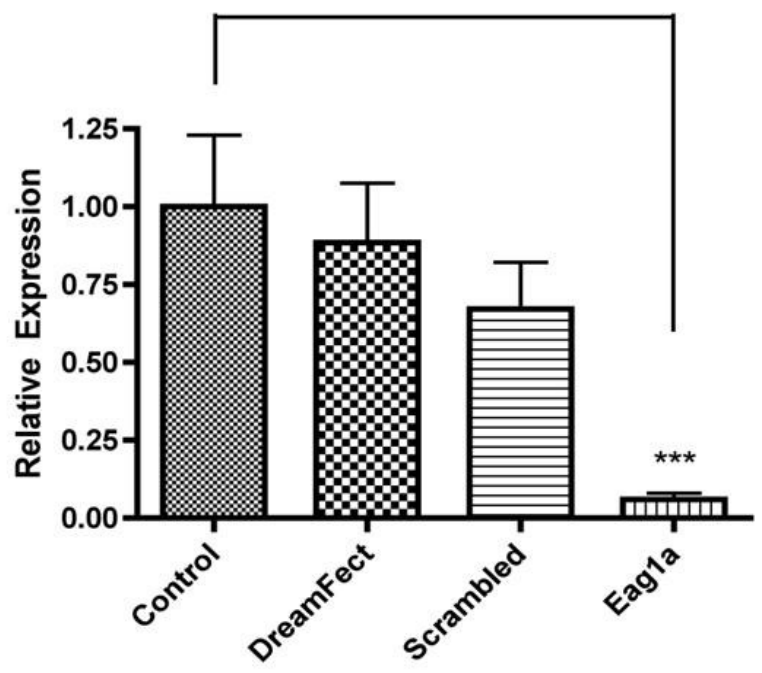

Figure 4.7 Reduction on Eag1 message in melanoma cells by siRNA. Relative expression of mRNA content in cells IPC298 (A) and IGR39 (B) treated with siRNA for Eag1a, $30 \mathrm{nM}$. The transfection reagent DreamFect was used as a control and the siRNA scrambled in the same concentration as the Eagla. $\mathrm{n}=3 .(* * *=$ $\mathrm{p}<0.001$ ). (Pfaffl, 2001). 
The reduction of mRNA levels produced by siRNA correlated with a reduction of protein content, as revealed in immunoprecipitation experiments. Figure 4.8 shows that, $30 \mathrm{~h}$. after transfection with siRNA specific for hEag1, the signal detected in immunoprecipitation for Eag1 protein was abolished.

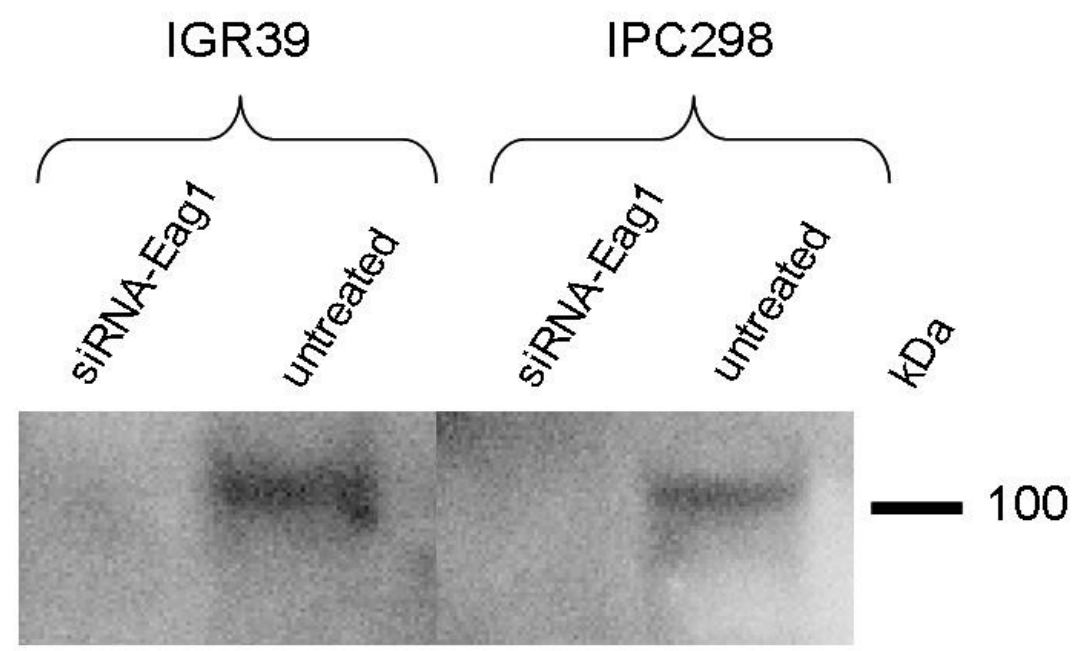

Figure 4.8 Reduction on Eag1 protein level in melanoma cells by siRNA. Cells were transfected with siRNA for Eag1 and after 30 hours the extract was prepared and Eag1 was immunoprecipitated with an anti-Eag1 monoclonal antibody (mAb 33) and detected with an anti-Eag1 polyclonal antibody (9391). 
Figure 4.9 shows the effect of siRNA treatment in the current levels of both cell types, IPC298 and IGR39. Although the current detected in IGR39 cells does not show the typical features of hEag1, anti-Eag1 siRNA reduced the current density by $80 \%$, indicating that the current is dependent on the mRNA for hEag1.

\section{IPC298}

A
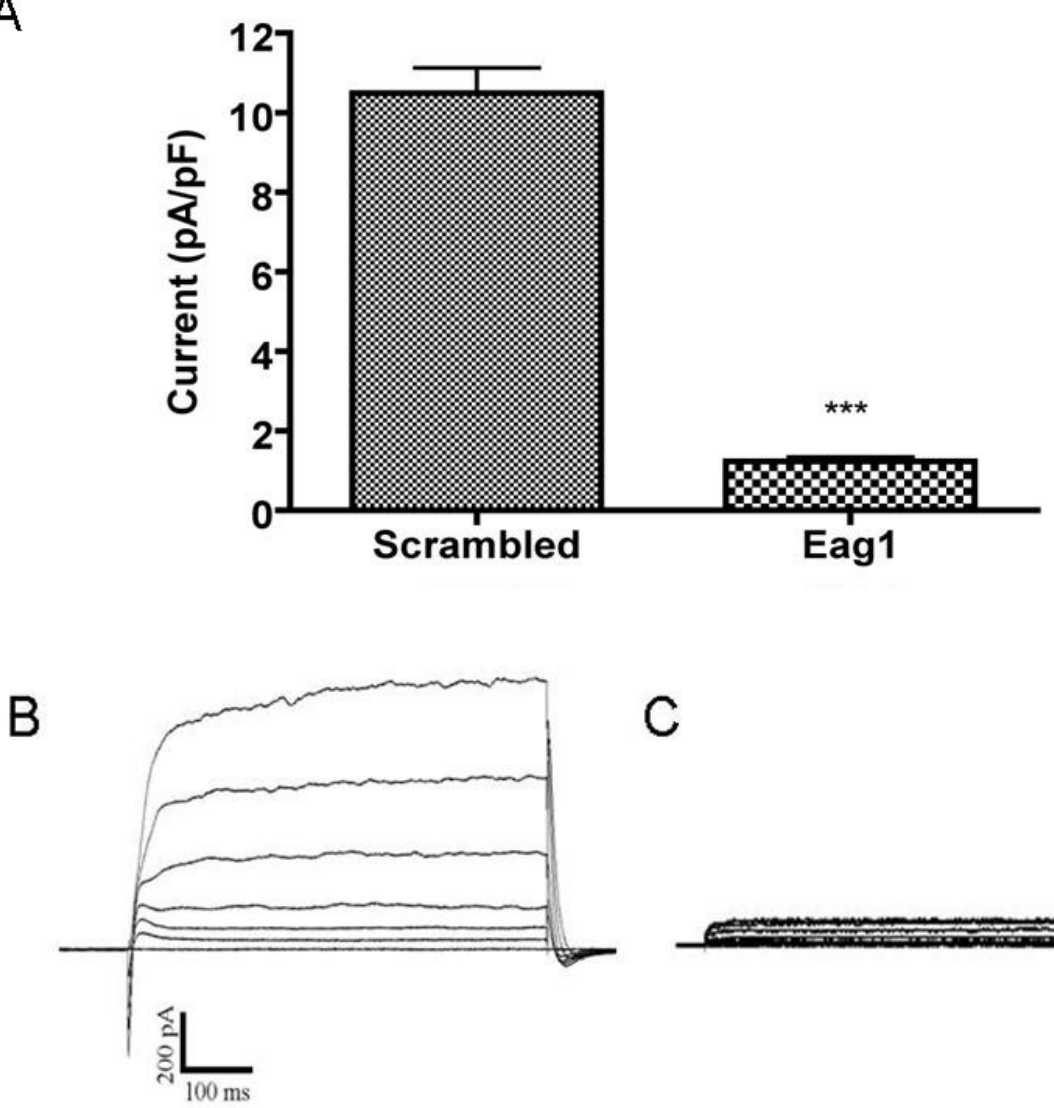

C 


\section{IGR39}

D
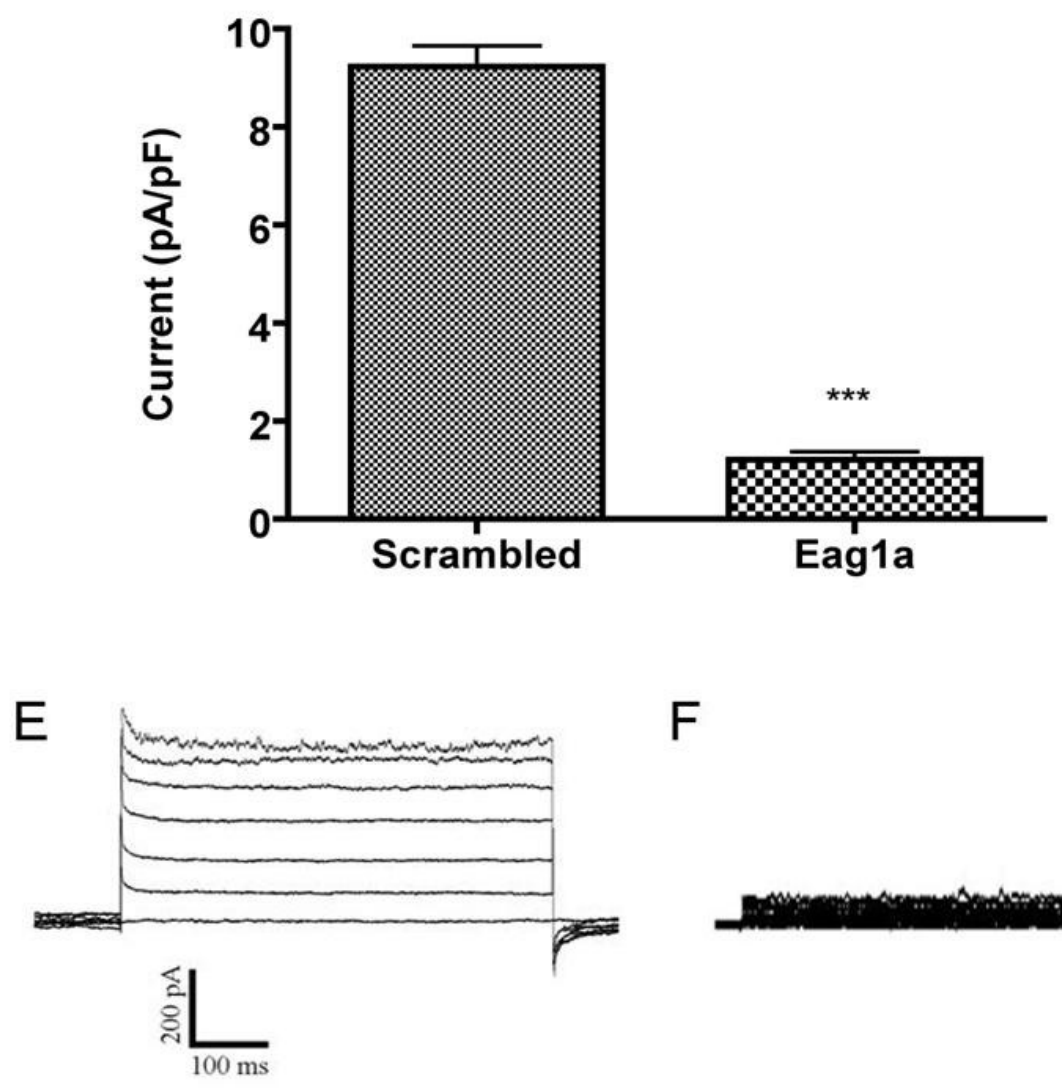

$\mathrm{F}$

Figure 4.9 Reduction on Eag1 current in melanoma cells by siRNA. Cells were transfected with siRNA for Eag1 and after 30 hours currents were measured. Traces were elicited by the same protocol depicted in Fig. 3.3. The graphs (A) and (D) show that more than $80 \%$ of the current in IPC298 (scrambled $n=8$, siRNA $n=11$ ) and IGR39 (scrambled $n=9$, siRNA $n=10$ ) was blocked by the siRNA for hEag1. Representative traces of the current in scrambled transfections are shown in (B) for IPC298 and (E) for IGR39 cells; and in siRNA for hEag1 transfections in (C) for IPC298 and (F) for IGR39. $(* * *=$ $\mathrm{p}<0.001)$. 


\subsection{Detection of new hEag1 Splice Variants in Melanoma Cell Lines}

\subsubsection{Detection of splice variants by nested-PCR}

Our hypothesis to explain the differences in Eag1 channel kinetics between the two cell lines was the presence of the splice variants. To test this, we used a Nested RTPCR strategy. This technique allows detecting low levels of circulating mRNA transcripts and also increases the specificity of the amplified product. The subsequent sequencing reactions of the nested PCR product (Figure 4.10B) revealed two new splice variants generated by exon skipping.

The whole Eag1 is composed by 11 exons as represented in Figure 4.10A. The expected sequence amplified should be around $2 \mathrm{~kb}$, from the full length of Eag1, as the one seen amplified in the transfected cell HEK293-Eag1. This $2 \mathrm{~kb}$ band is amplified in melanoma cell lines, IPC298 and IGR39 (Figure 4.10B). However, a smaller fragment is additionally amplified in the lanes from melanoma cells, with 700 bp in IPC298 and 500 bp for IGR39. 
A
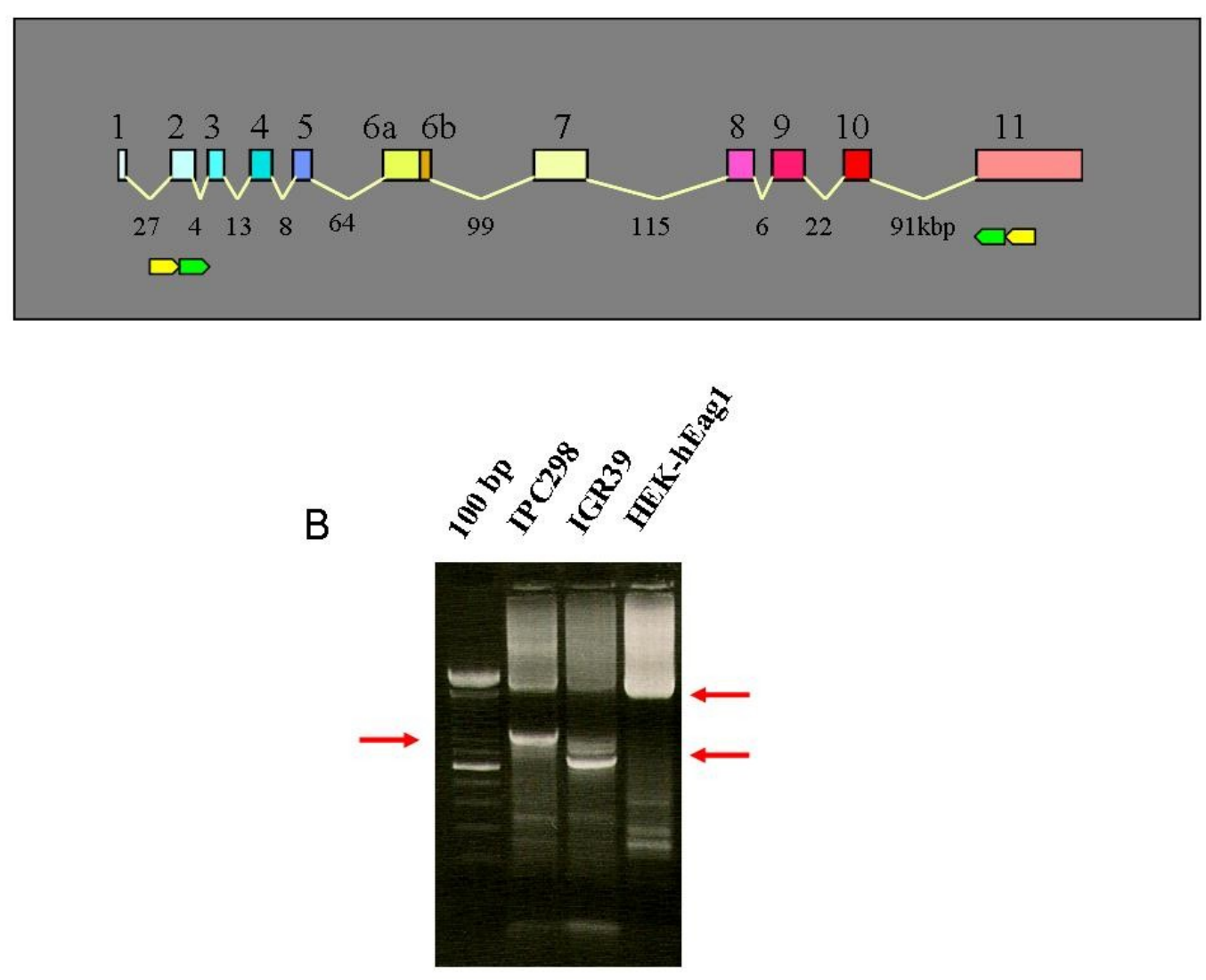

Figure 4.10 Detection of splice variants by Nested PCR. (A) scheme of the genomic structure of Eag1. The arrows in the Eag sequence represent the sites where the primers were located. Yellow arrows: external primers; green arrows: internal primers. In (B) a $1.5 \%$ agarose gel with Nested PCR products obtained with the specific primers for hEag1 represented in the scheme above. Lane 1: 100 bp markers. Lane 2, 3 and 4: respectively cDNAs for IPC298, IGR39 and HEK293-Eag1 transfected cells.

Sequencing of the amplified bands revealed the absence of exon 4 to 7 in IPC298 cells, and 4 to 9 in IGR39 cells. We did not detect any additional changes in the sequence. Both sequences keep the reading frame and could give rise to distinct proteins. The predict size of the IPC298 protein should be around $70 \mathrm{kD}$ and the one of IGR39 cells $65 \mathrm{kD}$. Based on their molecular weight we call the splice variants E70 and E65, respectively (Figure 4.11). 
A

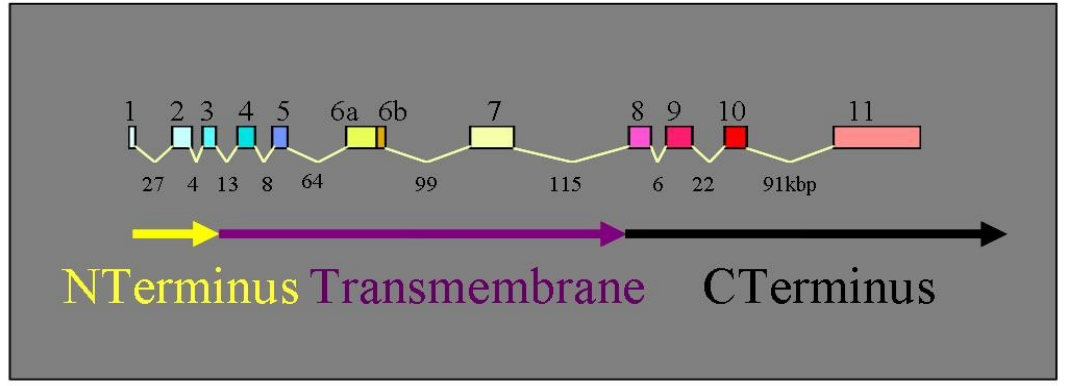

B $\quad$ IPC298

E70 Шा1

IGR39

E65 피

Figure 4.11 Representative schemes showing the two melanoma splice variants. (A) shows the whole Eag1 sequence and a relation between the protein and the coding region. In (B) the representative splice variants from IPC and IGR39 are shown.

Sequence analyses predict that E70 and E65 have no transmembrane domains and should not produce structural channels.

We could not find any mutation in the region that was preserved in the spliced sequence of both variants when compared to hEag1 (Figure 4.12). 


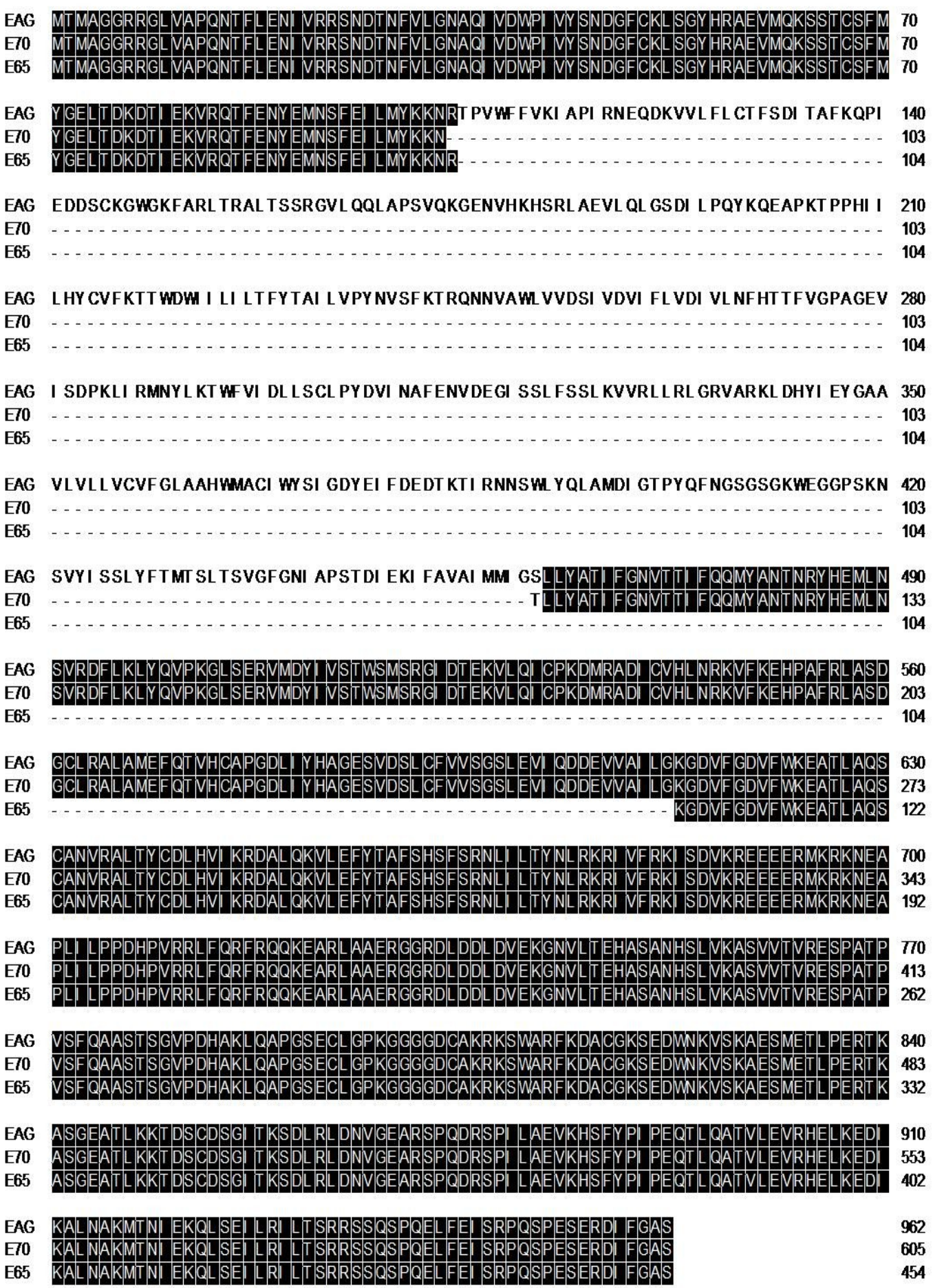

Figure 4.12 Sequence alignment of amino acid sequences of the Eag1 WT with the two alternative spliced forms E70 and E65. Residues conserved among different variants are shadowed. 


\subsubsection{Expression of splice variants in Xenopus leavis oocytes}

To determine whether these splice variants were translated into protein, we injected the cRNA in Xenopus oocytes, as described in Methods. After $48 \mathrm{~h}$. an extract of the whole oocyte was obtained, and we performed an immunoprecipitation as shown in Figure 4.13.

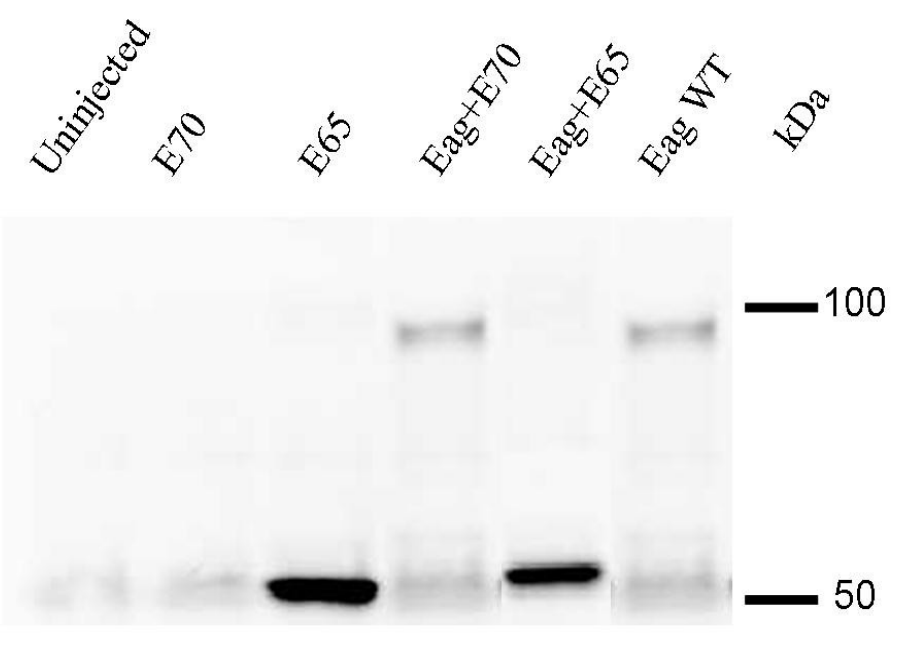

Figure 4.13 Expression of splice variants E70 and E65 protein in Xenopus oocytes. Western blot of 15 whole oocyte extract precipitated with an anti-Eag1 monoclonal antibody and detected with an anti-Eag1 polyclonal antibody.

Injection of E70 did not produce any detectable protein. However, injection of E65 gave rise to a band of estimated $54 \mathrm{kDa}$. The co-injection of Eag1 with E70 did not cause alteration in the Eag1 protein band detection, unlike when the co-injection was performed with E65. In the latter case we observed a strong reduction of the Eag1 band. Despite that we can not detect a protein band when Eag1 was co-injected with 
E65, we still can register a small but significant current. In the case where only the Eag1 was injected we detect a protein band, which is not so evident, but we can register a powerful current.

\subsubsection{Characterization of E65 and E70 effects on Eag1 current expressed in Xenopus leavis oocytes}

As mentioned before, E65 and E70 should not produce homomeric channels since they do not have the exons responsible for the transmembrane segments formation. However, it is conceivable that the splice products could physically or functionally interact with the full length Eag1. The splice variants could co-assemble with Eag1 channel subunits changing their surface expression and/or properties, or they could work as an intracellular signaling protein. To test this possibility, we injected Xenopus oocytes with the E65 and E70 cRNA alone, or together with the full length Eag1 cRNA and recorded ion currents after 48 h. using two-electrode voltage clamp.

When oocytes where co-injected with E70 (Figure 4.14B) we did not observe any difference when compared to the Eag1 wild type (Eag1 WT) (Figure 4.14A). However, co-expression of full length Eag1 with E65 (Figure 4.14C) resulted in a current with altered the IV (Figure 4.14D) characteristics. At very positive voltages, the current amplitude decreased (instead of increasing), a phenomenon known as inward rectification. As expected, oocytes injected with E65 or E70 cRNA alone did not produce any different currents than the endogenously expressed by the Xenopus oocytes (data not shown). 

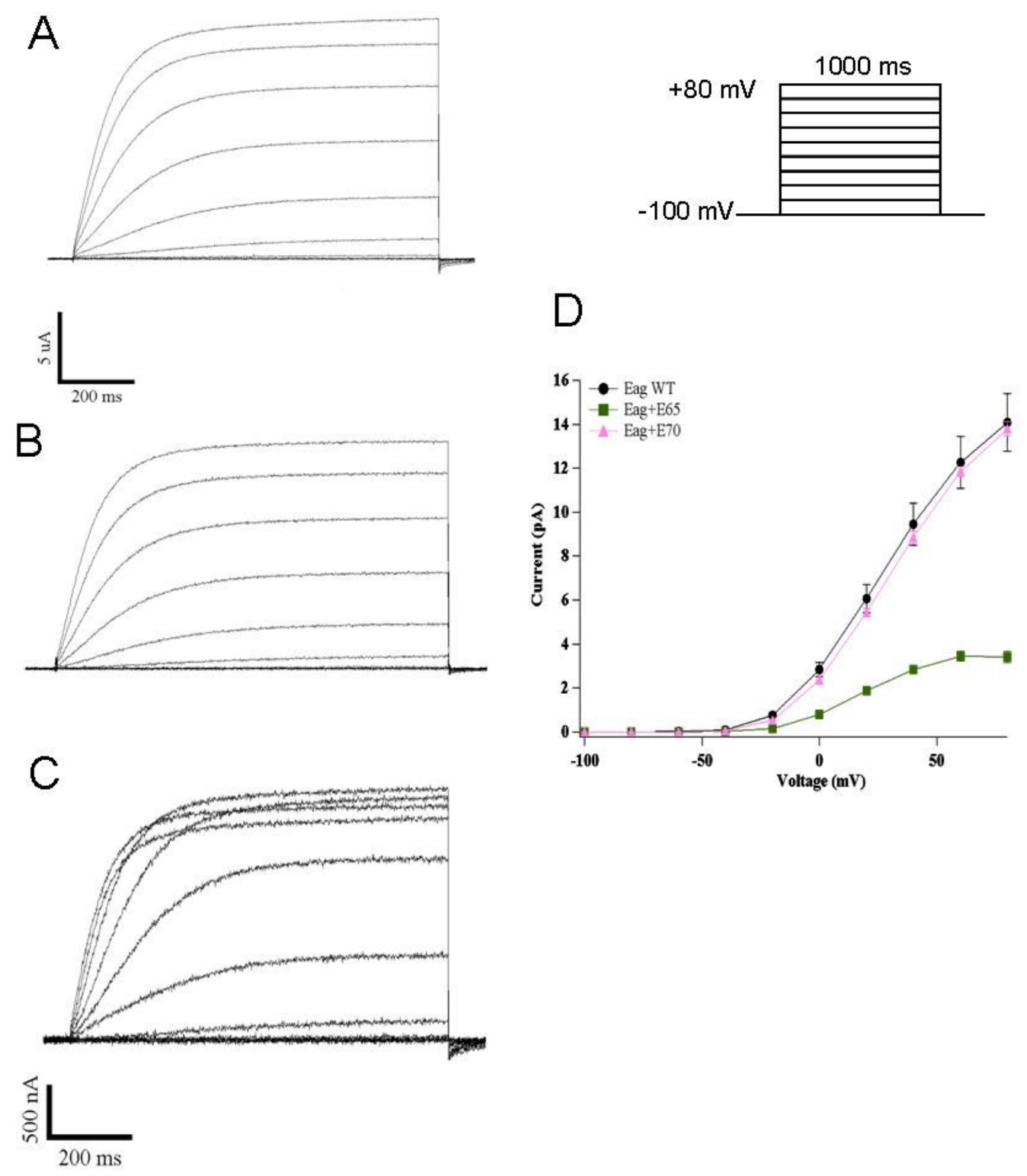

Figure 4.14 Functional characterization of E65 and E70 expressed together with Eag1 in Xenopus oocytes. Currents elicited by the depicted voltage protocol $(20 \mathrm{mV}$ increments) for Eag1 WT (A) and co-injected with E70 (B). In (C) the Eag1 was coinjected with E65. The corresponding I-V relationships are shown in (D), for Eag1 WT (black traces), Eag1+E70 (pink trace) and Eag1+E65 (green trace). 
As described before, the activation kinetics of Eag1 channels is slowed down by negative pre-pulses ("Cole-Moore shift"). Since this is characteristical for Eag1 channels we decided to verify whether or not the activation kinetics was changed in coinjected oocytes. The results are exemplified in Figure 4.15. No substantial difference was observed in the voltage shift when any of the splice variants were co-injected with Eag1 WT.
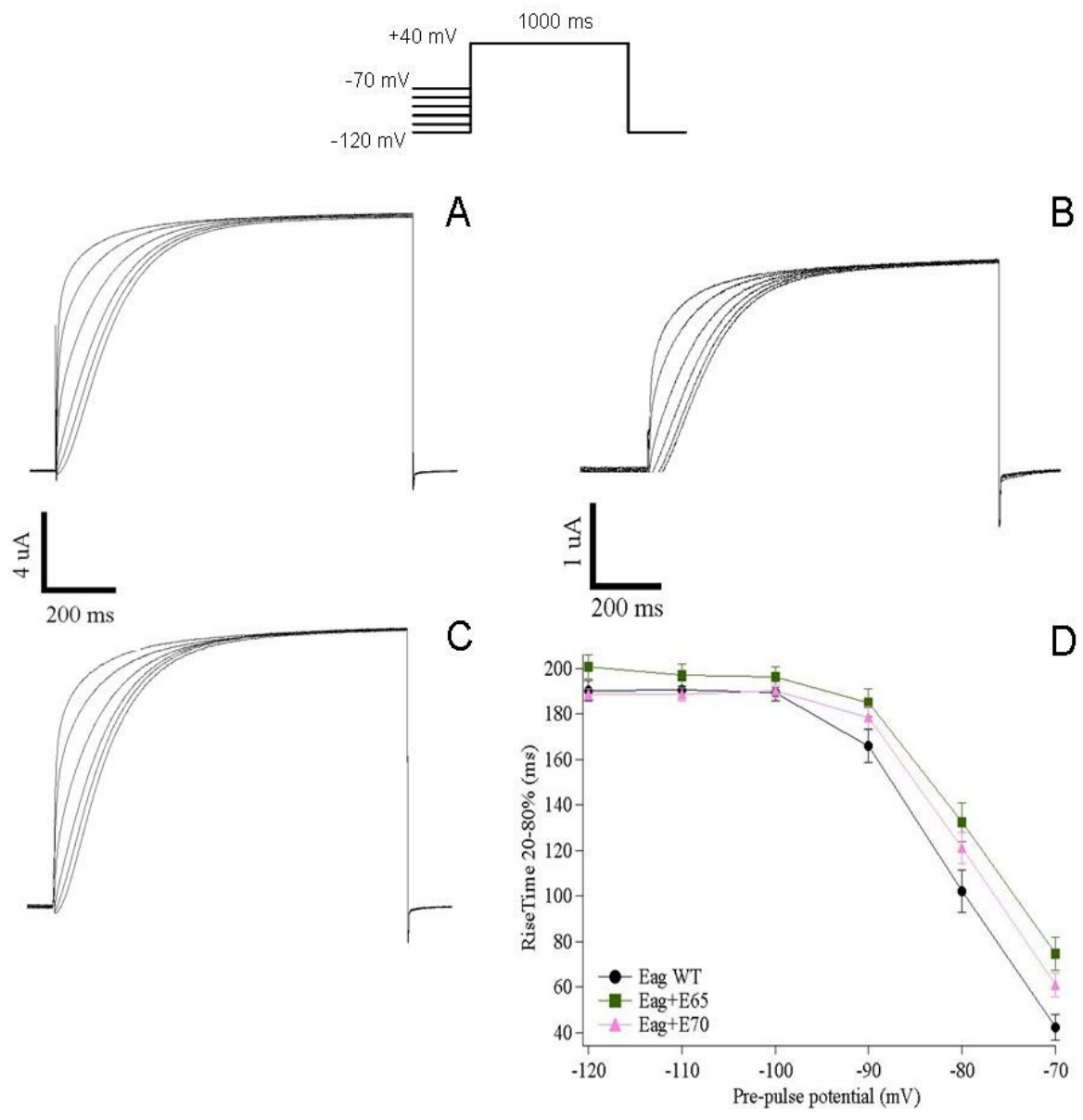

Figure 4.15 Activation kinetics of Eag1 co-injected with E65 and E70 in Xenopus oocytes. The depicted voltage protocol represents that the cells were clamped for $500 \mathrm{~ms}$ to different negatives holding voltages $(-120 \mathrm{mV}$ until $-70 \mathrm{mV})$ and then depolarized $(+40 \mathrm{mV})$ to activate $\mathrm{K}^{+}$channels. In (A) is the control Eag WT, (B) Eag+E65 and (C) Eag+E70. (D) from the currents traces show in (A), (B) and (C) the time to reach $80 \%$ of maximal current was obtained and plotted $v s$. the holding voltage. 
To determine the specificity of the interaction between E65 and Eag1 we used another ion channel, Kv1.4, as a control. This is a voltage-gated potassium channel, which also presents $\mathrm{N}$ - and C-terminus in the intracellular side of the cell. Figure 4.16A shows the control current elicited by wild types Kv1.4 channels, and 4.16B when coinjected with E65. We observed that no discernible effect was produced by coinjections of E65 with Kv1.4: the I-V curves superimposed (Figure 4.16C).
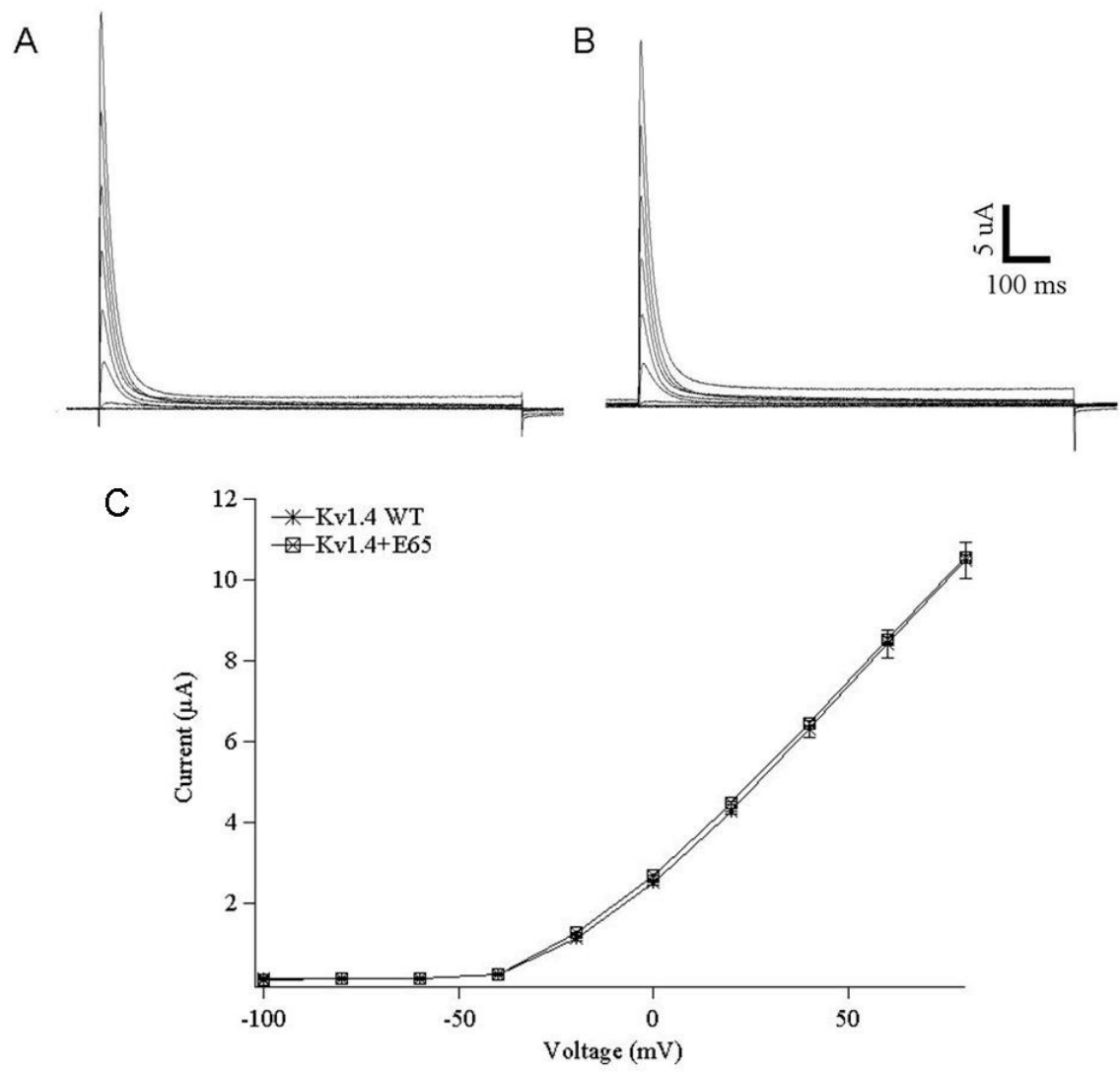

Figure 4.16 Interaction with E65 is specific for Eag1 channels. Currents elicited by the depicted voltage protocol $(20 \mathrm{mV}$ increments) of Fig. 3.14. (A) and (B) represent, respectively, the currents for Kv1.4 WT and or Kv1.4 co-injected with E65. The corresponding I-V relationship are shown in (C), where $\left(^{*}\right)$ is for Kv1.4 WT and ( $\square$ ) for Kv1.4+E65. 


\subsubsection{Maturation induced by E65 in Xenopus leavis oocytes}

In Xenopus laevis, immature oocytes are arrested in the late G2 phase of the first meiotic division until progesterone released from the surrounding follicle cells triggers completion of meiosis I and progression to meiosis II. The mature oocyte remains arrested in metaphase II until fertilization. Within minutes of progesterone exposure, a decrease occurs in the level of cyclic AMP (cAMP), which is believed to attenuate the activity of cAMP-dependent protein kinase. This presumably leads to diminished phosphorylation of an unidentified protein or proteins inhibitory to meiotic maturation (Smith, 1989). The events of maturation, including germinal vesicle breakdown (GVBD), chromosome condensation, and formation of the metaphase spindles during both meiosis I and II, occur upon activation of mitosis-promoting factor (MPF), a complex consisting of p34cdc2 and cyclin B2 (Solomon, 1993). Once Cdc-2cyclin B is activated, it targets multiple substrates for phosphorylation which in turn trigger the mitotic events of nuclear envelope breakdown, chromosome condensation, and spindle assembly (Philpott and Yew, 2008; Brüggemann et al., 1997).

Previous data from our group (Brüggemann, Stühmer and Pardo, 1997) described that the process of Xenopus oocytes maturation leads to a reduction of rEag1 current amplitude. They reproduced this behavior by injection of mitosis-promoting factor (a complex of cyclin $\mathrm{B}$ and $\mathrm{p} 34^{\mathrm{cdc} 2}$ ), the main molecule responsible for the maturation in oocytes.

We observed here that the currents identified when we co-injected Eag1 plus E65 splice variant are very similar to those elicited when the oocytes are mature (Figure 4.17). At the moment of the injection the oocytes were immature, and they were kept in a solution containing theophillin, a maturation inhibitor which helps to 
maintain high cAMP levels. Based on these results we hypothesized that the splice variant can be inducing maturation of the oocytes.

To verify the maturation process in oocytes, after the injection of Eag WT and Eag+E65, a progesterone induced-maturation (as a progesterone pulse of $5 \mu \mathrm{g} / \mathrm{ml}$ ) was performed and then the currents were measured. The oocytes were in presence of progesterone for $5 \mathrm{~min}$ and then they were placed in NFR without progesterone for at least 2 hours before electrophysiology measurements.

Figure 4.18 shows in (A) the behavior of the Eag1 WT current after the progesterone treatment and (B) when the oocytes were co-injected with E65. We observed that in both of them the IV linearity is lost and rectification sets in (C), indicating that behavior of the current in both situations are similar. 

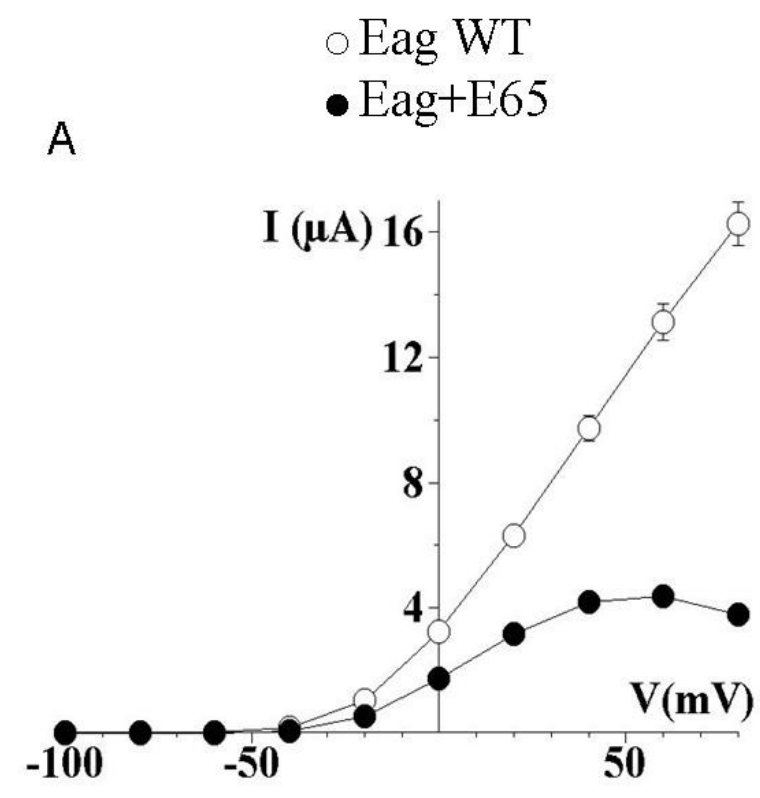

$\circ$ Eag WT

- Eag WT (Mature oocyte)

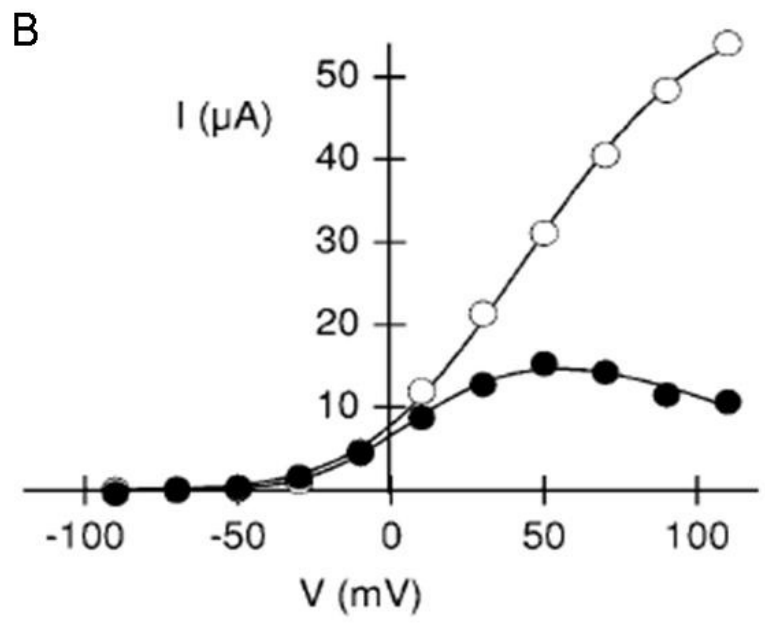

Brüggemann, Stühmer and Pardo, 1997.

Figure 4.17 Comparison between Eag1 WT vs Eag1+E65 in non mature and mature Xenopus oocytes. In (A) currents registered in non mature oocytes injected with Eag WT (०) or Eag+E65 (•) is represented. (B) shows the result published by Brüggemann, Stühmer and Pardo (1997) showing the rEag WT currents before (o) and after maturation $(\bullet)$. 

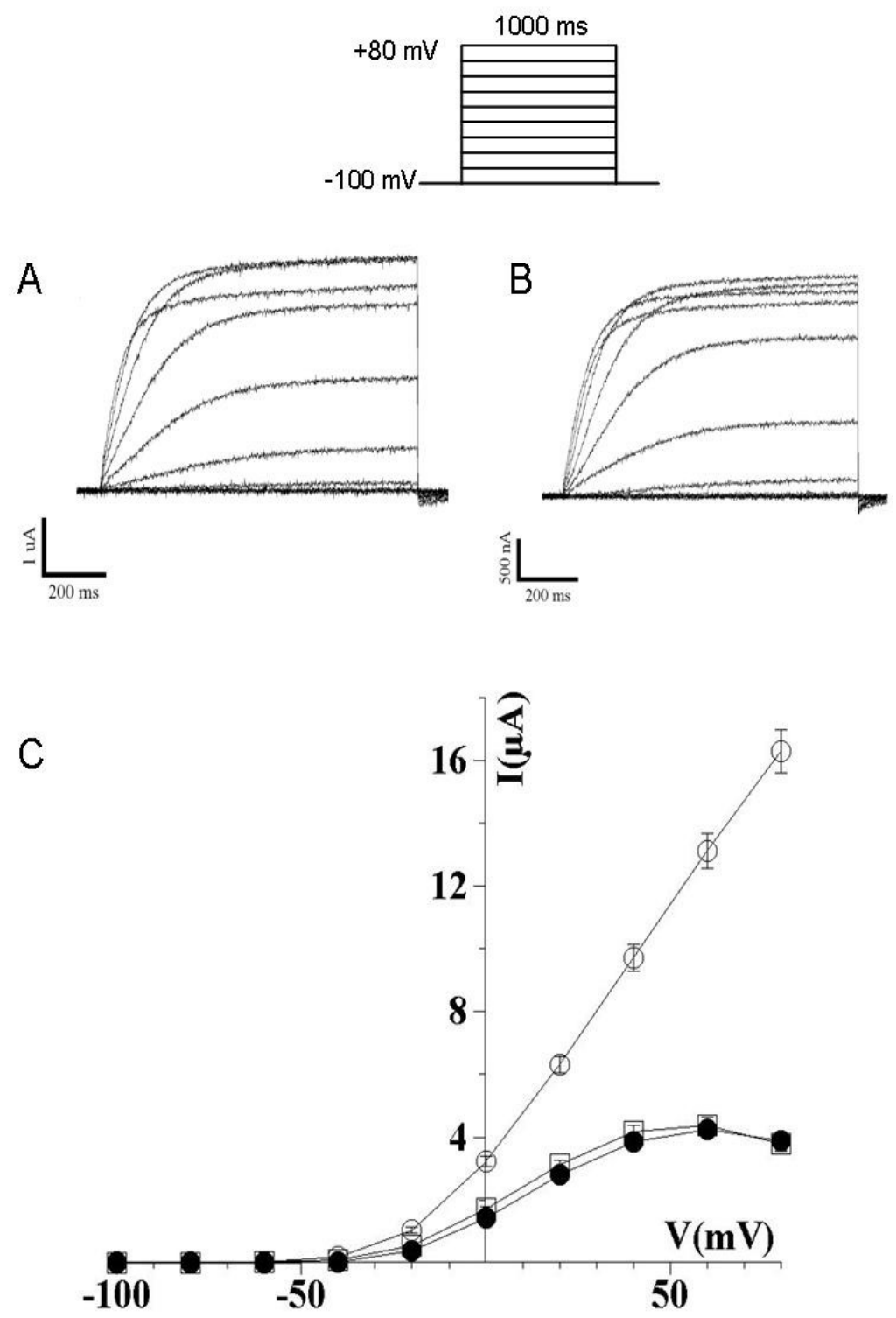

Figure 4.18 Maturation induced by progesterone in injected Xenopus oocytes. (A) represents currents registered in oocytes injected only with Eag WT and matured by a progesterone pulse (5 min). (B) shows currents elicited by co-injection of Eag+E65. (C) shows Eag WT $\mathrm{I}-\mathrm{V}$ relations from non-mature oocytes $(\mathrm{O})$, Eag WT in mature oocytes () and Eag+E65 (•). 
To test our hypothesis that E65 is inducing maturation in oocytes, we performed the classical germinal vesicle breakdown (GVBD) maturation test. The GVBD happens when the nuclear maturation is reinitiated. The germinal vesicle forms when the nucleus swells and enlarges to produce a watery nucleus. It is thought that the unique structure and composition of the germinal vesicle may protect the genetic material. When the membrane of the germinal vesicle disintegrates, the swollen nucleus is easily recognized, appearing to "break down".

We injected immature oocytes with our splice variant E65, and after $48 \mathrm{~h}$ an extract of these oocytes was obtained. The extract was treated with RNase to eliminate the pre-injected cRNA. This extract was then injected into fresh oocytes kept in NFR+theophilin. After $2 \mathrm{~h}$ the oocytes showed the classical GVBD signs, indicating that the cell cycle had continued (Figure 4.19).

Table 3 shows the number of oocytes injected with E65 that exhibited GVBD.

\begin{tabular}{|c|c|c|c|}
\hline $\begin{array}{c}\text { KIND OF INJECTION } \\
\text { IN OOCYTES }\end{array}$ & NUMBER & $\begin{array}{c}\text { NUMBER OF VESIBLE } \\
\text { GVBD }\end{array}$ & $\begin{array}{c}\text { NUMBER OF DEAD } \\
\text { OOCYTES }\end{array}$ \\
\hline $\begin{array}{c}\text { INJECTED WITH E65 } \\
\text { EXTRACTS }\end{array}$ & 90 & 48 & 13 \\
\hline $\begin{array}{c}\text { INJECTED WITH } \\
\text { UNINJECTED EXTRACTS }\end{array}$ & $\mathbf{6 0}$ & - & $\mathbf{1 0}$ \\
\hline $\begin{array}{c}\text { INJECTED WITH } \\
\text { EAG1 cRNA }\end{array}$ & 30 & - & - \\
\hline
\end{tabular}

Table 3 - Number of oocytes that exhibited GVBD. 

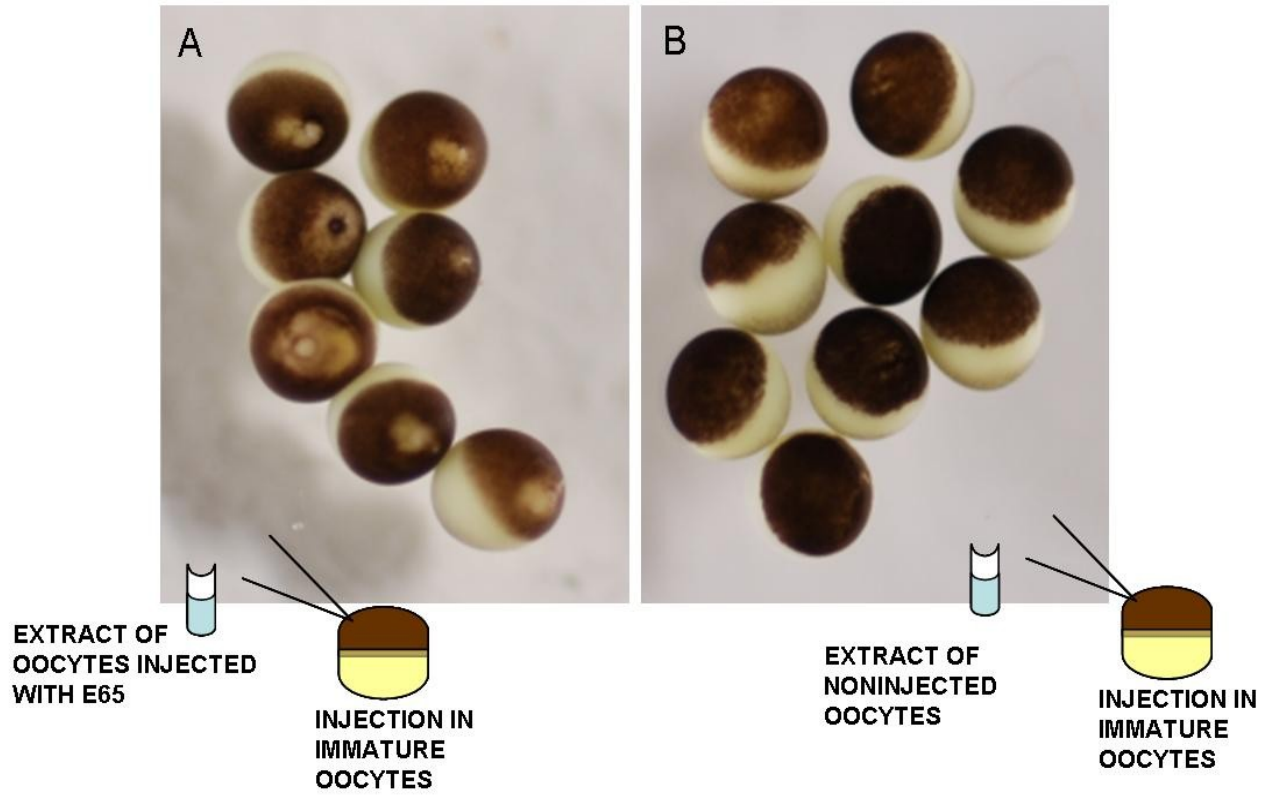

Figure 4.19 Maturation induced by E65 in Xenopus oocytes. (A) Oocytes injected with the extract from previous oocytes injected with E65. The white spots on top of the animal pole are the GVBD; (B) oocytes injected with extract from uninjected oocytes.

The activation of the cell cycle requires many enzymes and several events of intracellular signalization. To try to understand how the E65-induced maturation happens we decided to test whether cyclin B2 was active (Figure 4.20). We observed that the cyclin B2 level in oocytes that did not receive the progesterone pulse (A) showed very low basal levels in both injected and control oocytes. When the oocytes received a pre-pulsed with progesterone (B), then we observed a increase in cyclin B2, independently of the cRNA injected. 
These results indicate that the maturation induced by E65 in oocytes happens independently of cyclin B2.

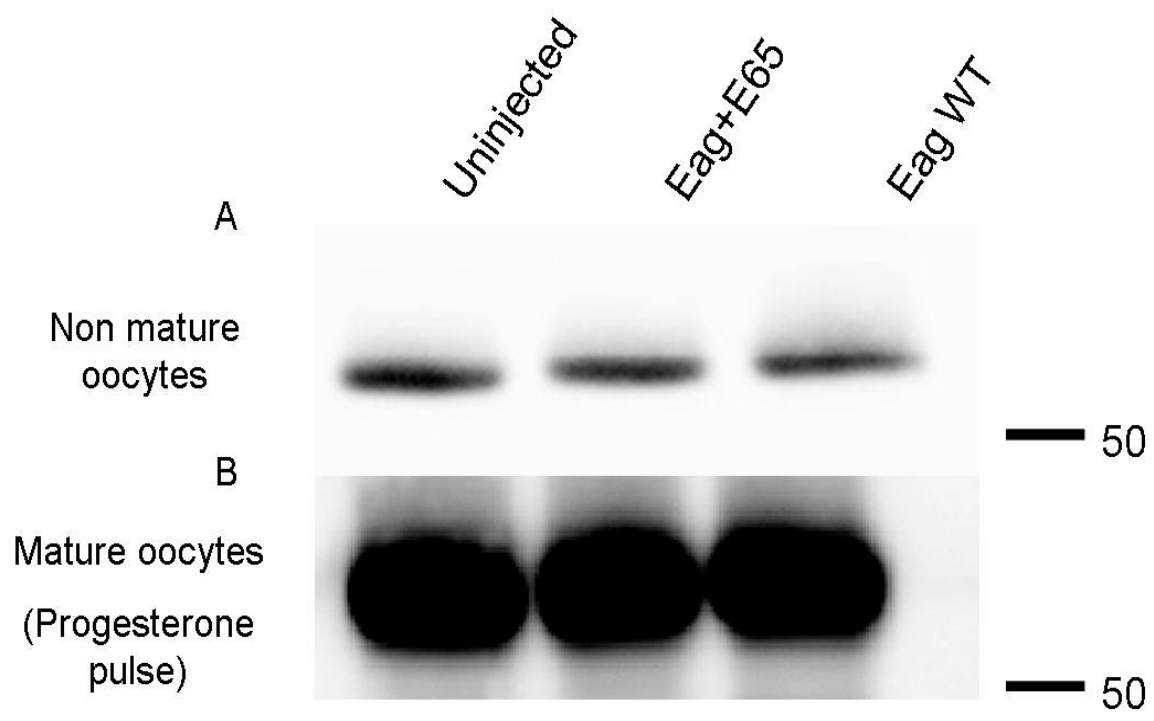

Figure 4.20 E65-induced maturation in Xenopus oocytes is cyclin $\mathbf{B} 2$ independent. Western-blot using extract from 15 oocytes. Immunoprecipitation and detection was done using a monoclonal cyclin B2 antibody. (A) Non-mature oocytes injected with the cRNA combinations or not injected, and (B) Oocytes after the progesterone pulse. 


\subsubsection{Northern-Blot analysis of the variant mRNA}

To estimate the relative size of the mRNA encoding for E65 we performed Northern-blot analysis using an exon probe. Figure 4.21 shows the annealing of a specific probe for the C-terminus of the Eag1 channel corresponding to the $10-11$ exons. Using this probe we expect to observe the full length Eag1 band and the alternative spliced variant, which shares the same C-terminus.

We did not detect the full length the hEag1 band in the melanoma cell lines IPC298 and IGR39, and neither in human brain positive control, although a band had previously been detected using a different probe (Occhiodoro et al., 1998). The mRNA is however detected by PCR. That appears to be a common problem (Asano et al., 2004) attributable to low mRNA abundance.

In the HEK293-Eag1 plus E65 transfected cells, the expected presence of two bands, $\sim 4 \mathrm{~kb}$, and $\sim 2.5 \mathrm{~kb}$ was detected. The IGR39 cell line also showed two bands, one stronger $(\sim 4 \mathrm{~kb})$, and the other weaker $(\sim 2 \mathrm{~kb})$, which were also detected in IPC298 cells, and still we could detect a smaller $(\sim 1.5 \mathrm{~kb})$ in IPC298 cells. Untransfected HEK cells were used as a negative control for unspecific binding. HEK293-Eag1 we detect also two bands, $\sim 4 \mathrm{~kb}$ and the smaller $\sim 2 \mathrm{~kb}$. 


\section{mRNA}

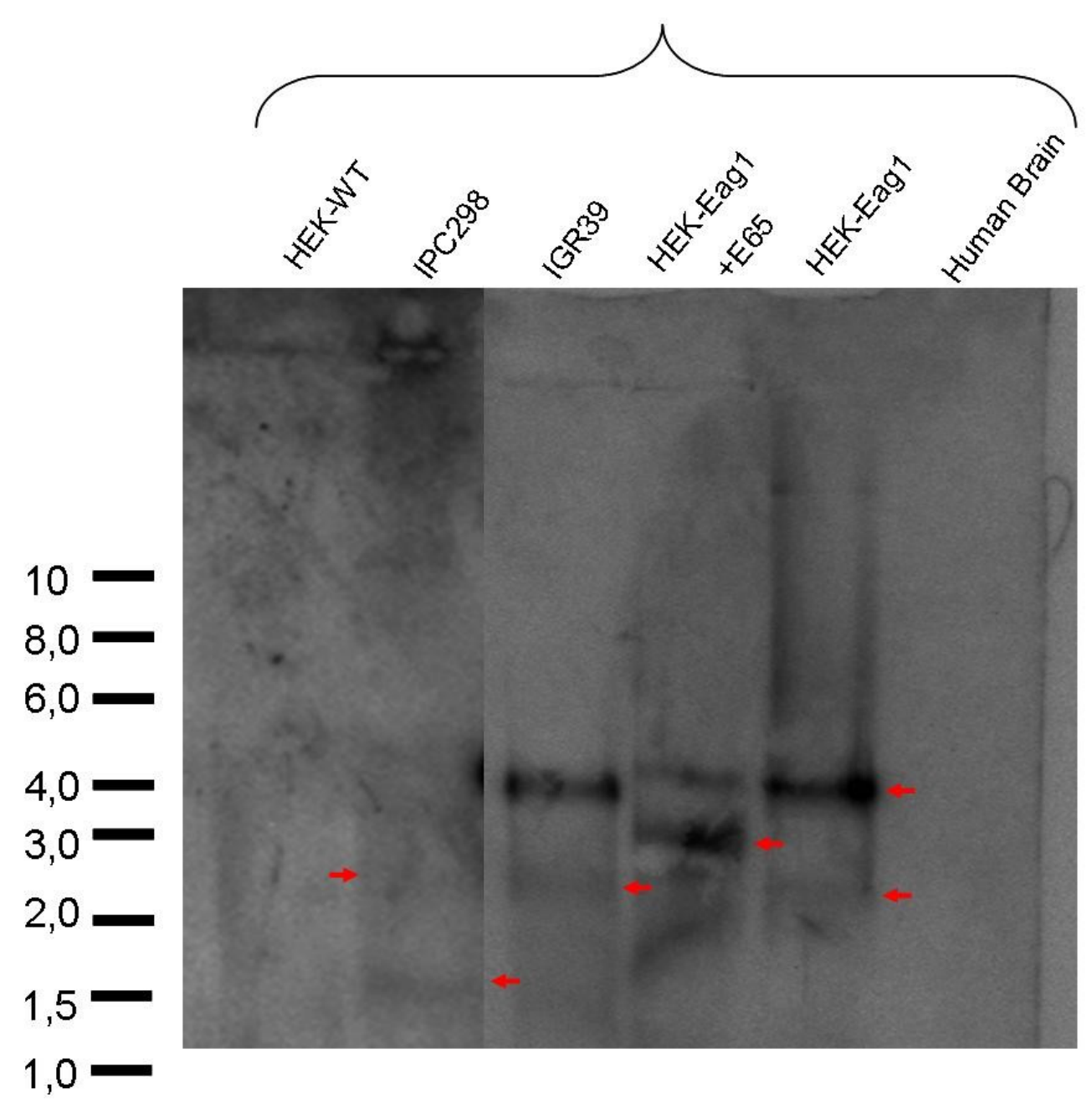

Figure 4.21 Northern blot analysis of variant mRNA expression in human cells. $10 \mu \mathrm{g}$ of mRNA from the cell lines indicated were separated in a $2 \%$ formaldehyde agarose gel, transferred to Hybond $\mathrm{N}$ membranes and hybridized overnight to a $700 \mathrm{bp}$ DNA probe for the C-terminus of Eag1 channel $\left({ }^{32} \mathrm{P}\right.$-C-terminus). The contrast is different in lines referent to IPC298 because the signal was very week. 


\subsection{Subcellular localization of E65 splice variant}

In order to clarify whether the obvious lack of transmembrane domains at E65 would render a soluble protein, we fused the C-terminus of E65 with the fluorescent protein Venus. The resulting cDNA was expressed in HEK-293 cells and analyzed by confocal laser scanning fluorescence microscopy as described in methods. E65-venus constructs resulted in a diffuse expression pattern in the whole cytoplasm, with the nuclear region empty (Figure 4.22).

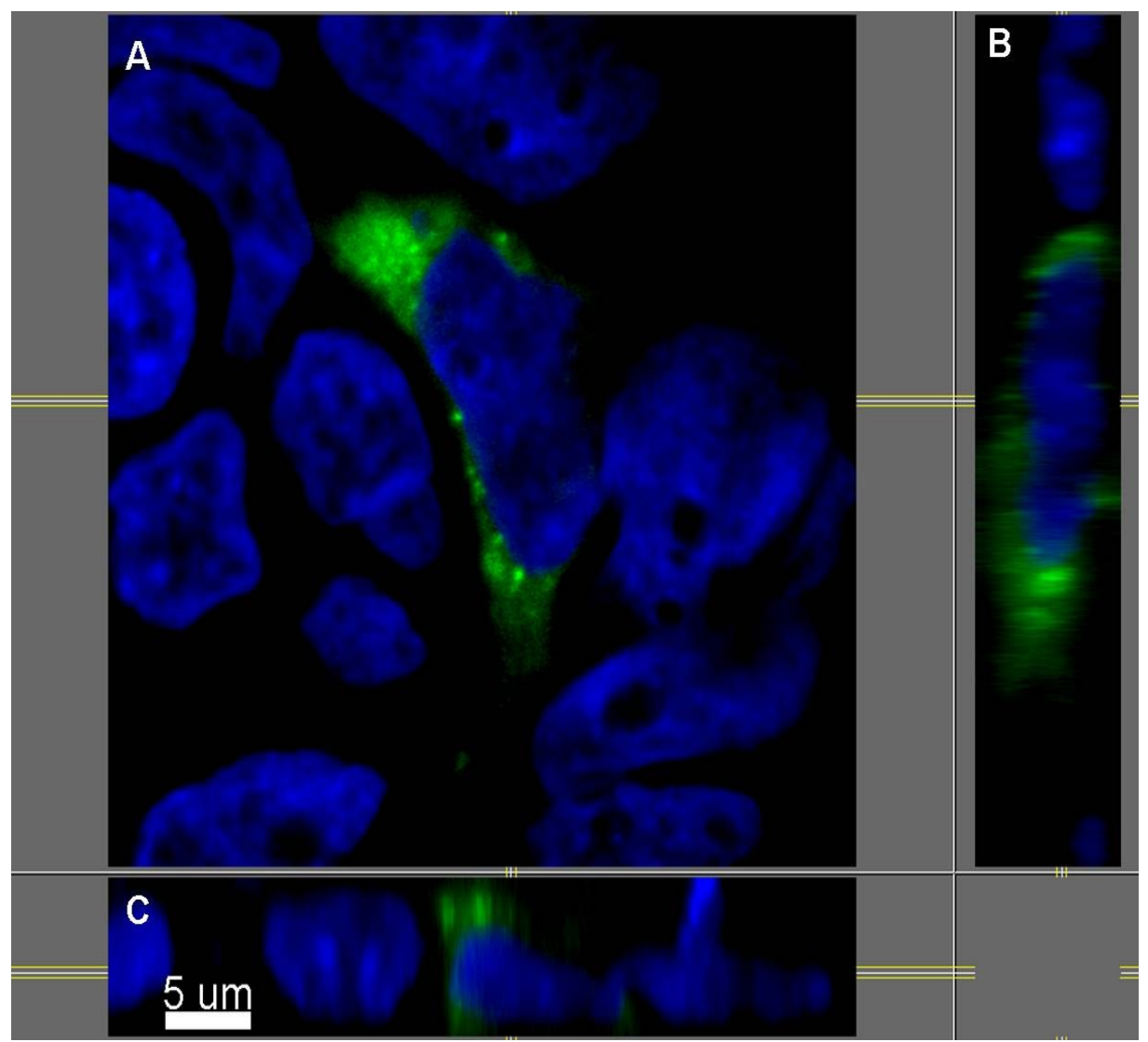


Figure 4.22 Subcellular localization of HEK293-Eag1 transfected with E65-venus. In these confocal microscopic pictures the E65Venus in green and the nucleus in blue (ToPro) can be seen. (A) shows the cytoplasmic localization of E65 and we confirm this in a different view of the nucleus in (B) and (C). (D) shows a stack performed in the confocal microscopy and confirms the cytoplasmic dispersion of the E65 splice variant.

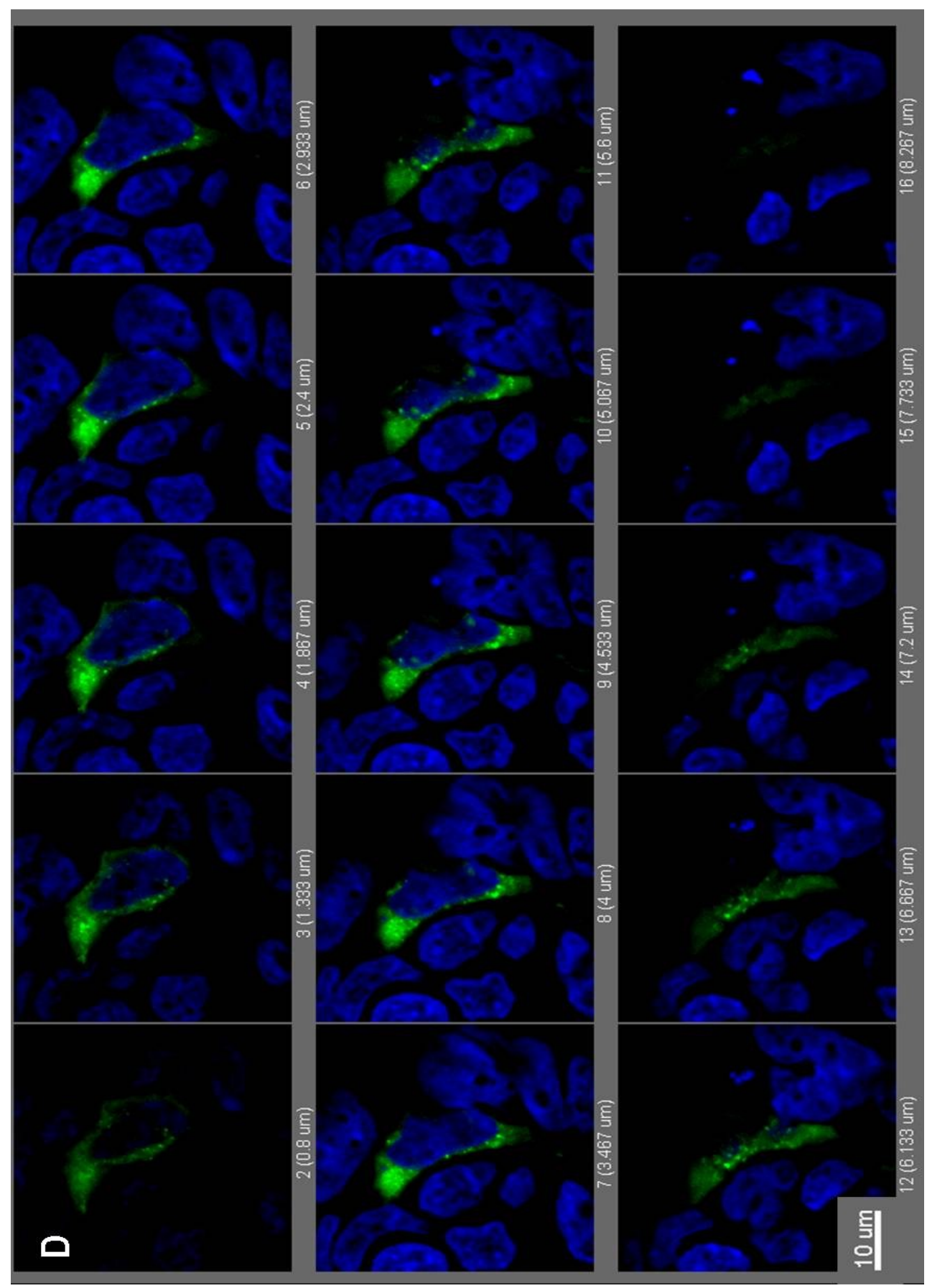




\subsection{Other Experiments}

\subsubsection{Expression of E65 in Neural Stem Cells}

Neural stem cells (NSC) are self-renewing cells with the capacity to differentiate into neurons, astrocytes and oligodendrocytes. Adult NSC's are extremely rare and are believed to reside only in discrete regions of the hippocampus and the subventricular zone. Due to their therapeutic potential, considerable attention has been focused on identifying the sources of stem cells, the signals that regulate their proliferation and the specification of neural stem cells towards more differentiated cell lineages (Gage, 2000). These cells are often identified based upon the presence of molecular markers that are correlated with the stem and/or progenitor state along with the absence of differentiated phenotypes as assessed through marker analyses (Palmer et al., 1997).

Experiments using rat NSC (rNSC) revealed that they show a diffuse staining for a monoclonal antibody (mAb 62) against the pore region of the Eag1 potassium channel, as observed in Figure 4.23. In contrast, we did not detect expression of the channel using RT-PCR (Data not shown). A different antibody against the pore region (mAb 49) shows also staining in these NSC in flow cytometry (A. Barrantes-Freer, unpublished data).

We performed a nested PCR using the same primers as for the melanoma cells. Figure 4.24 shows that in the positive control, HEK293-Eag1, a band of the expected length can be seen. In RNA from IGR39 cells, we detected a band corresponding to 
both the full length and the shorter splice variant E65. However, NSC showed only the shorter variant.

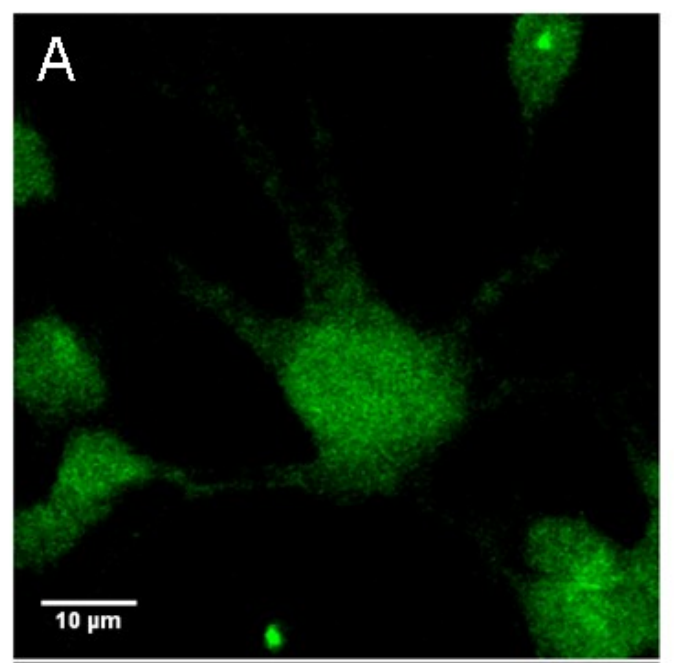

Figure 4.23 Confocal microscopy of Eag1 in rNSCs. The picture show the staining for Eag1 using an antibody against the pore region of the channel (A) the staining for nucleus using ToPro (B) and the merge image $(\mathrm{C})$. 


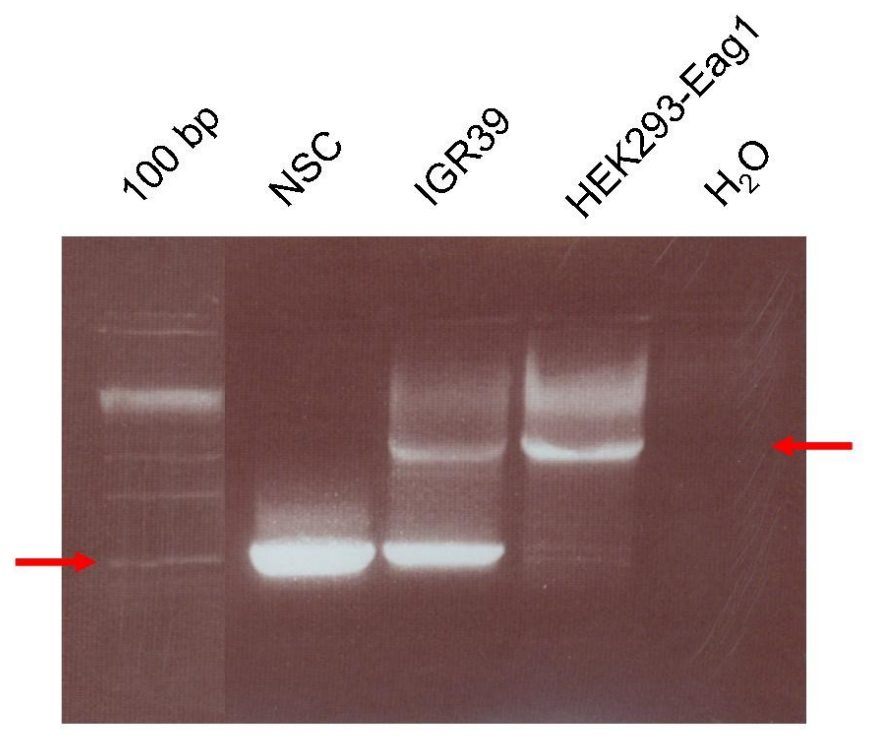

Figure 4.24 rNSCs splice variant detection by Nested-PCR. A $1.5 \%$ agarose gel with Nested PCR products obtained with the specific primers for Eag1. Lane 1: 100 bp markers. Lane 2, 3, 4 and 5: cDNA's for rNSC's, IGR39, HEK293-Eag1 and $\mathrm{H}_{2} \mathrm{O}$, respectively.

Sequence analyses showed that the band amplified by rNSC's have the same spliced regions that the splice variant found in IGR39 melanoma cell line, the exons 4 9 are missing in the sequence (Data not shown). 


\subsubsection{Identification of low-abundance alternatively spliced mRNA}

Alternative splicing of mRNA precursors generates multiple transcripts from a single primary transcript. Identification and verification of splice variants and cloning of the corresponding isoforms is crucial for analyzing gene expression and understanding the related functions. Wang and coworkers (2008) showed that for a specific gene, the abundance of the transcripts produced can vary significantly and is subject to various regulations. It could be difficult to detect low-level splicing variants when others are present in high abundance. The authors describe a method for the amplification of low-abundance mRNA splice variants for such situations, which introduces a hydrolysis step prior to the conventional RT-PCR. After the transcripts are reverse transcribed into cDNA, the high abundance cDNA transcript is suppressed from amplification by cleavage at the chosen exon to enhance the amplification of the lowabundance transcripts that do not have the target exon and are normally undetectable.

As first strategy we digested exons that were present only in the Eag1 full length, and also, exons that were present in both known splice variants. Figure 4.25 shows the amplified transcripts after cleavage of different exons in the Eag1 sequence. We observed that when the exon 6a was digested (Fig. 4.25A), an exon that is present only in the Eag1 full length, a $1 \mathrm{~kb}$ band, a $500 \mathrm{bp}$ and a $650 \mathrm{bp}$ was produced in all tested cells. The transfected HEK293-Eag1 still shows amplification of full-length after the digestion because the transfected cells express a massive amount of Eag1 message. When the digested exon was the exon 7 (Fig. 4.25B) that is present only in the full length, the same bands, as in the exon 6 digestion, were amplified. Interestingly, when the digested exons were present in both known splice variants, the full length and the 
E65 and E70, like exon 10 (Fig. 4.25C) and exon 11 (Fig. 4.25D), we observed that for IPC298, IGR39 and HEK293-Eag1 the results were the same, but when we look at the NSC's we can detect a $2 \mathrm{~kb}$ band corresponding to the Eag1 full length that was not amplified before.

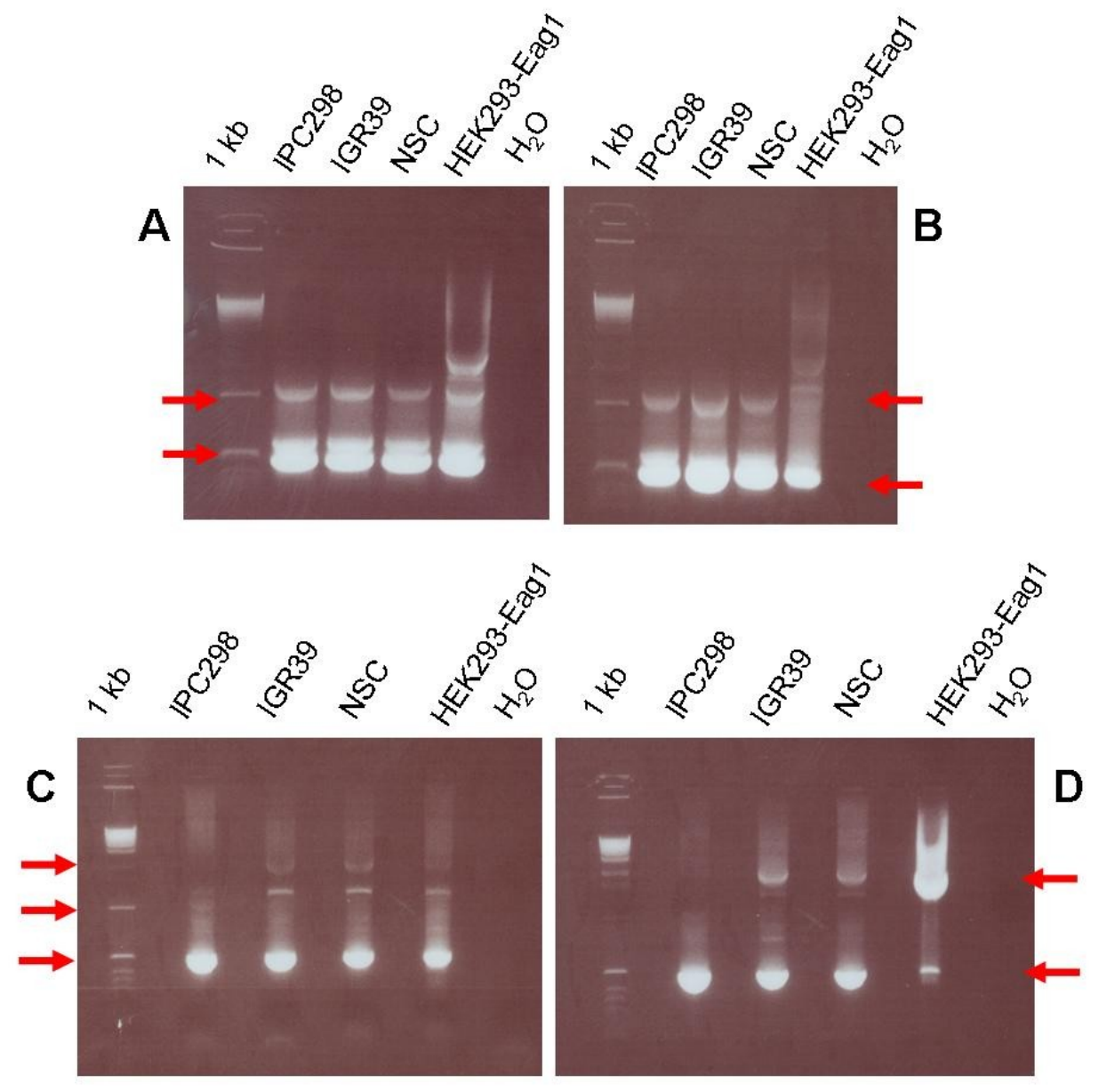

Figure 4.25 Identification of Eag1 gene transcripts that are expressed differentially in melanoma cells and NSC via exon exclusive RT-PCR. Cleavage of exon 6 (A), exon 7 (B), exon 10 (C) or exon 11 (D) from these cells using restriction enzymes detected two more bands by the conventional RT-PCR. 


\section{Discussion}

\subsection{Eag1 in Melanoma Cells}

The rapid rise in melanoma incidence and the high lethality because of the highly metastatic rate has motivated efforts to define the genetic and environmental factors driving melanoma genesis and progression (Kabbarah and Chin, 2005). Melanoma responds poorly to chemotherapy and radiotherapy; several alternative methods of treatment have been investigated, including hormone therapy (Rizk \& Ryan, 1994), immunotherapy (Evans\& Manson, 1994) and therapy directed to ion channels.

The plasma membrane in melanocytes and melanoma cells possesses a variety of ion channels, which are thought to be involved in the proliferation, differentiation, and malignant alteration of cells and thus may contribute to tumor development (Allen et al., 1997; Wonderlin \& Strobl, 1996). Among these ion channels is the Eag1, a known potassium channels with high oncogenic potential (Pardo et al., 1999). Here we show that these two melanoma cell lines investigated, IPC298 and IGR39 express Eag1 potassium channel, and that this channel contributes to the proliferation of these cell lines (Figure 1.6). 
In contrast to previous reports (Gavrilova-Ruch et al., 2002; Meyer and Heinemann, 1999), we detect the presence of Eag1 at the RNA (Figure 4.1) and protein level in IGR39 cells (Figure 4.2) and also a functionality of the channel in the melanoma cell line IGR39 that was effectively blocked by a specific siRNA (Figure 4.9).

The current expressed in IGR39 cells is not sensitive to prepulse potential (Figure 4.4), causing the characteristic shift present in Eag1 currents. This cell line expresses an Eag1 ion channel with altered properties (Figure 4.3) or a non-Eag1 channel that is completely dependent of mRNA for Eag1, since when we used siRNA specific against Eag1, the current present in IGR39 cells was abolished (Figure 4.9). Based on the results obtained, we believe that this cell line expresses Eag1 channels, but somehow with different kinetics. There is evidence for many ion channels that interaction with accessory proteins alter their kinetics. Along this line, it is conceivable that Eag1 interacts with different partners in IGR39 and IPC298 melanoma cell lines, either because Eag1 itself is different in both cell lines, or because the accessory subunits expressed are not the same in both lines.

The activation mechanism of opening the ion channel is regulated by the S4 transmembrane segment, which is the voltage sensor. When the membrane depolarizes, the positive charges in S4, and the negative charges in S2 and S3 move with respect to each other. The S4 regions apparently move like paddles (Jiang et al. 2003), and this leads to opening of the channel gate, located at the intracellular side of the pore (Wray, 2004). Thus, a new intracellular interaction with this segment of the channel could be responsible for a modified conformational change of the channel, leading to a different sensitivity to voltage changes across the membrane. 
Lörinczi and colleagues (2008) show that the voltage control of the channels is dependent on all transmembrane domains, at least, together with S4, S5 and S6. The authors reported that chimeras mutated in the domains S5 and S6 open at potentials more negative compared to the Eag WT. We have to pay attention to these domains in the channel, and also with the loop between then because it could be an interesting interaction site for intracellular proteins that could be interfering with the biophysical properties of the channel.

\subsection{Melanomas and Splice Variants}

Alternative splicing is the process whereby identical pre-mRNA molecules are spliced in different ways, and this is important in normal development as a means of creating protein diversity in complex organisms (Black, 2003; Maniatis and Tasic, 2002). Many alternative splicing events have been noted in human development, especially in the brain (Grabowski and Black, 2001; Venables, 2002).

Aberrant splicing has been found to be associated with various diseases, including cancer. Mutations in splicing sites regulatory elements within the nucleotide sequence and alterations in the cellular-splicing-regulatory machinery both result in changes in the splicing pattern of many cancer-related genes (Pajares et al., 2007).

In the melanoma cells studied we have found two new splice variants, called E65 and E70 (Figures 4.10 and 4.11). These splice variants have no transmembrane domains, so they can not form functional ion channels. Lewis and colleagues (2009) show that a spliced form of the TRIP8b protein, which is a hyperpolarization-activated cyclic nucleotide-gated $(\mathrm{HCN})$ channel (h channel) interaction protein, participates in 
the regulation of the $\mathrm{h}$ channel, as well in trafficking as in function. Since the splice variants found here are not expected to form a functioning ion channel on their own, it is likely that they play a role in intracellular signaling.

The splice variants were detected by RT-PCR (Figure 4.10) and we could also detect mRNA signals at levels compatible with the variant in IGR39 and IPC298 cells (Figure 4.21). We observed that transfected HEK293-Eag1 cells also express a shorter splice variant indicating that the alternative splice process can happen in transfected systems. This is not unique, Sun and colleagues (2009) reported that a splice variant was found in COS cells transfected with a full length Eag1 cDNA.

Based on the results obtained from PCR performed with the cDNA digested regions (Figure 4.25) we conclude that the E65 splice variant is expressed in IGR39 cells, and also in IPC298 melanoma cells as well as NSC and HEK293-Eag1 cells. We detect bands with other sizes, which could be responsible for other spliced transcripts. The signal observed by antibody staining of the NSC could be explained by antibody binding to the low-abundant full-length Eag1.

\begin{tabular}{|c|c|c|c|c|c|c|c|c|c|c|c|}
\hline \multicolumn{7}{|c|}{ BANDS IDENTIFIED AFTER DIGESTION } \\
\hline CELL LINE & \multicolumn{3}{|c|}{ EXON 6A } & \multicolumn{3}{c|}{ EXON 7 } & \multicolumn{3}{c|}{ EXON 10 } & \multicolumn{2}{c|}{ EXON 11 } \\
\hline IPC298 & $500 \mathrm{bp}$ & $650 \mathrm{bp}$ & $1 \mathrm{~kb}$ & $500 \mathrm{bp}$ & $650 \mathrm{bp}$ & $1 \mathrm{~kb}$ & \multicolumn{3}{|c|}{$500 \mathrm{bp}$} & \multicolumn{2}{c|}{$500 \mathrm{bp}$} \\
\hline IGR39 & $500 \mathrm{bp}$ & $650 \mathrm{bp}$ & $1 \mathrm{~kb}$ & $500 \mathrm{bp}$ & $650 \mathrm{bp}$ & $1 \mathrm{~kb}$ & $500 \mathrm{bp}$ & $1.5 \mathrm{~kb}$ & $2 \mathrm{~kb}$ & $500 \mathrm{bp}$ & $2 \mathrm{~kb}$ \\
\hline NSC & $500 \mathrm{bp}$ & $650 \mathrm{bp}$ & $1 \mathrm{~kb}$ & $500 \mathrm{bp}$ & $650 \mathrm{bp}$ & $1 \mathrm{~kb}$ & $500 \mathrm{bp}$ & $1.5 \mathrm{~kb}$ & $2 \mathrm{~kb}$ & $500 \mathrm{bp}$ & $2 \mathrm{~kb}$ \\
\hline HEK-Eag1 & $500 \mathrm{bp}$ & $650 \mathrm{bp}$ & $1 \mathrm{~kb}$ & $2 \mathrm{~kb}$ & $500 \mathrm{bp}$ & $1.5 \mathrm{~kb}$ & $500 \mathrm{bp}$ & $1.5 \mathrm{~kb}$ & $2 \mathrm{~kb}$ & $500 \mathrm{bp}$ & $2 \mathrm{~kb}$ \\
\hline
\end{tabular}

Table 4 - Bands identified via exon exclusive PCR. 
Upon co-expression of splice variants with full-length Eag1, E70 did not alter the features of the Eag1 current, but E65 induced specific effects (Figure 4.13). When we co-injected E65 and full-length Eag1 we observed a significant inward rectification (Figure 4.17).

It is still unclear which is the real role of E70, whether it exists at all, and how E65 interacts in a different expression system, like mammalian cells. There are several questions that remain unanswered on this topic. However, this work opens a new line of study for Eag1 channels.

\subsection{Xenopus oocytes maturation induced by $\mathbf{E 6 5}$}

Xenopus oocytes are arrested in meiotic I phase. Progesterone induces the resumption of meiotic maturation, which requires protein synthesis to bring about $\mathrm{Cdc} 2$ activation. The synthesis of cyclin B and c-Mos, a kinase that activates the mitogenactivated protein kinase pathway in oocytes, is clearly upregulated in response to progesterone (Haccard and Jessus, 2005). These two messengers are the responsible factors for MPF activation and cell cycle progression in Xenopus oocytes.

As described by Brüggemann, Stühmer and Pardo (1997), the Eag1 channels are regulated during cell cycle. When Eag1 channels are expressed in mature oocytes, the current is strongly inhibited and has a remarkable rectification. When we co-injected E65 together with Eag1 channels in immature oocytes, we observed the same effect reported by these authors before the current decreases and becomes rectifying (Figure 4.14). This work gives a molecular explanation of the results obtained by Brüggemann, Stühmer and Pardo in 1997. 
E65 could be changing the intracellular ionic concentration, and increasing the $\mathrm{Na}^{+2}$ levels (Pardo et al., 1998). To address this, we tested oocytes during maturation, doing the classical GVBD test, and we observed that injection of previous extract from oocytes injected with E65 can cause maturation in fresh oocytes (Figure 4.19), indicating that there are active kinases, or the same product that is capable to activate the MPF complex causing the GVBD in the non mature oocyte. We conclude that the MPF complex needs to be active, that E65 does not induce an alteration of intracellular $\mathrm{Na}^{+}$, because the simple alteration of $\mathrm{Na}^{+}$alone is not responsible for the sensibility of the channel. The channel became sensible to the increased $\mathrm{Na}^{+}$concentration by a MPF-mediated activation process.

Investigating this process, Camacho et al (2000) found similar results that can complete the puzzle. They show that cell-cycle-related changes in the behavior of Eag1 currents are most likely due to microtubular reorganization, since they are restricted to the $\mathrm{M}$ phase of the cycle, and can be reproduced by disruption of the microtubules.

E65 induces maturation in oocytes. Once E65 induces MPF the cell-cycle progression occurs. The MPF and the cell cycle progression modify the reorganization of the microtubules, which leads to a reorganization of the cytoskeletal interactions. This would also affect interactions with ion channels, which in turn can be responsible for alteration in their currents-conduction properties. How E65 is causing MPFactivation remains unclear. We know that it is a cyclin B2 independent pathway (Figure 4.20) and also that it is independent of a decrease in cAMP, since the oocytes were kept in a solution containing theophillin, a substance that helps to maintain high levels of cAMP.

The observed correlation between cell cycle progression and cytoskeletal 
interactions is very interesting. However, in a different system, such as in a mammalian cell, the function of E65 could be different. Since E65 could not induce cell cycle progression, could this protein interact in a different way with the Eag1 channel causing a different phenotype?

The oocyte was used as a viable heterologous expression system because we know that once we inject cRNA there is no possibility for the oocyte to reprocess the RNA, and therefore we are confident that what is expressed corresponds to what was injected. The same can not be assumed for a cell line, because when we transfected with cDNA, it was reprocessed, as shown in Fig. 4.25. Therefore, a new splice variant can be generate by transfection something that we actually wanted to exclude. 


\section{Bibliography}

Alberts, B., Johnson, A., Lewis, J., Raff, M., Roberts, K. \& Walter, P. Molecular biology of the cell. 5th edition, Garland Science, New York, 2008.

Allen, D.H.; Lepple-Wienhues, A., Cahalan, M.D. Ion channel phenotype of melanoma cell lines. J. Membr. Biol., Jan; 1;155(1):27-34, 1997.

Agarwal, J.; Griesinger, F; Stühmer, W.; Pardo, L.A. The potassium channel Ether à go-go is a novel prognostic factor with functional relevance in acute myeloid leukemia. Molecular Cancer, 9:18, 2010.

Amigorena, S., Choquet, D., Teillaud, J.L., Korn, H., Fridman, W.H. Ion channel blockers inhibit $B$ cell activation at a precise stage of the G1 phase of the cell cycle. Possible involvement of K+ channels. J. Immunol., Mar 15; 144 (6): 2038-45, 1990a.

Amigorena, S., Choquet, D., Teillaud, J.L., Korn, H., Fridman, W.H. Ion channels and B cell mitogenesis. Mol. Immunol. Dec; 27 (12): 1259-68, 1990.

Arcangeli, A., Bianchi, L., Becchetti, A., Faravelli, L., Coronnello, M., Mini, E., Olivotto, M. \& Wanke, E. A novel inward-rectifying $\mathbf{K}^{+}$current with a cellcycle dependence governs the resting potential of mammalian neuroblastoma cells. J. Physiol., 489 (Pt 2), 455-471, 1995.

Ashcroft, F.M. ATP-sensitive potassium channelopathies: focus on insulin secretion. J. Clin. Invest. 115:2047-2058, 2005.

Ashcroft, F.M. New uses for old drugs: neonatal diabetes and sulphonylureas. Cell Metabolism 11, March 3, 2010.

Aubert, C., Rougé, F., Galindo, J.R. Tumorigenicity of human malignant melanocytes in nude mice in relation to their differentiation in vitro. J. Natl. 
Cancer Inst., May; 64(5): 1029-40, 1980.

Balch, C.M.; Soong, S.J.; Gershenwal, J.E.; Thompson, J.F.; Reintgen, D.S.; Cascineli, N.; Urist, M.; McMasters, K.M.; Ross, M.I.; Kirkwood, J.M.; Atkins, M.B.; Thompson, J.A.; Coit, D.G.; Byrd, D.; Desmond, R.; Zhang, Y.; Liu, P.Y.; Lyman, G.H.; Morabito, A. Prognostic factors analysis of 17,600 melanoma patients: validation of the American Joint Committee on Cancer melanoma staging system. J. Clin. Oncol. Aug; 15;19(16):3622-34, $2001 \mathrm{a}$.

Balch, C.M.; Buzaid, A.C.; Soong, S.J.; Atkins, M.B.; Cascinelli, N.; Coit, Fleming, I.D.; D.G.; Gershenwal, J.E.; Houghton, A.Jr.; Kirkwood, J.M.; McMasters, K.M.; Mihm, M.F.; Morton, D.L.; Reintgen, D.S.; Ross, M.I.; Sober, A.; Thompson, J.A.; Thompson, J.F. Final version of the American Joint Committee on cancer staging system for cutaneous melanoma. J. Clin. Oncol. Aug; 15;19(16):3635-48, 2001b.

Balch, C.M.; Buzaid, A.C.; Soong, S.J.; Atkins, M.B.; Cascinelli, N.; Coit, D.G.; Fleming, I.D.; Gershenwal, J.E.; Houghton, A.Jr.; Kirkwood, J.M.; McMasters, K.M.; Mihm, M.F.; Morton, D.L.; Reintgen, D.S.; Ross, M.I.; Sober, A.; Thompson, J.A.; Thompson, J.F. New TNM melanoma staging system: linking biology and natural history to clinical outcomes. Semin. Surg. Oncol. 21(1):43-52, 2003.

Bantounas, I., Phylactou, L.A. \& Uney, J.B. RNA interference and the use of small interfering RNA to study gene function in mammalian systems. J. Mol. Endocrinal, 33, (3): 545-557, 2004.

Barajas-Farias, L.M.; Bermúdez-Ocaña, D.; Diaz, L.; Larrea, F.; Ávila-Chávez, E.; Cadena, A.; Hinojosa, L.M.; Lara, G.; Villanueva, L.A.; Vargas, C.; HernándezGallegos, E.; Camacho-Arroyo, I.; Dueñas-González, A.; Pérez-Cárdenas, E.; Pardo, L.A.; Morales, A.; Taja-Chayeb, L.; Escamilla, J.; Sánchez-Peña, C.; Camacho, J. Ether a' go-go potassium channels as human cervical cancer markers. Cancer Research 64, 696-7001, Oct; 1, 2004.

Barros, F., del Camino, D., Pardo, L., Palomero, T., Giráldez, T. \& de la Pena, P. Demonstration of an inwardly rectifying $\mathrm{K}^{+}$current component modulated by thyrotropin-releasing hormone and caffeine in gh3 rat anterior pituitary cells. Pflugers Arch. 435, 119-129, 1997.

Bataille, V. \& Vries, E. Melanoma - part 1: epidemiology, risk factors and prevention. BMJ, Nov; 29, vol.337, 2008.

Bauer, C.K.; Engeland, B.; Wulfsen, I.; Ludwig, J.; Pongs, O.; Schwarz, J.R. RERG is a molecular correlate of the inward-rectifying $K$ current in clonal rat pituitary cells. Receptors Channels. 6(1):19-29, 1998.

Bauer, C.K. \& Schwarz, J. R. Physiology of EAG K ${ }^{+}$channels. J. Membr. Biol., 182, (1): 1-15, 2001. 
Becchetti, A., Fusco, M.D., Crociani, O., Cherubini, A., Restano-Cassulini, R., Lecchi, M., Masi, A., Arcangeli, A., Casari, G. \& Wanke, E. The functional properties of the human ether-à-go-go-like (HELK2) $\mathbf{K}^{+}$channel. Eur. J. Neurosci., 16, (3): 415-428, 2002.

Beeton, C.; Wulff, H.; Standifer, N.E.; Azam, P.; Mullen, K.M.; Pennington, M.W.; Kolski-Andreaco, A.; Wei, E.; Grino, A.; Counts, D.R.; Wang, P.H.; LeeHealey, C.J.; Andrews, B.; Sankaranarayanan, A.; Homerick, D.; Roeck, W.W.; Tehranzadeh, J.; Stanhope, K.L.; Zimin, P.; Havel, P.J.; Griffey, S.; Knaus, H.G:; Nepom, G.T.; Gutman, G.A.; Calabresi, P.A.; Chandy, K.G. Kv1.3 channels are a therapeutic target for $\mathbf{T}$ cell-mediated autoimmune diseases. Proc. Natl. Acad. Sci. USA. Nov; 14;103(46):17414-9, 2006.

Benzaquen, L.R., Brugnara, C., Byers, H.R., Gatton-Celli, S. \& Halperin, J.A. Clotrimazole inhibits cell proliferation in vitro and in vivo. Nat. Med., 1, (6): 534-540, 1995.

Bertrán, G.C.; D’Alessio, C.; Kotsias, B.A. Ion channels in non excitable cells. Medicina, 55(5 Pt 1):449-56, 1995.

Béroud, C.; Hamroun, D.; Collod-Béroud, G.; Boileau, C.; Soussi, T.; Claustres, M. UMD (Universal Mutation Database): 2005 update. Hum. Mutat., Sep; 26(3):184-91,2005.

Bezanilla, F. The voltage-sensor structure in a voltage-gated channel. TRENDS in Biochemical Sciences, vol.30, $\mathrm{n}^{\circ} .4$, April 2005.

Bianchi, L., Wible, B., Arcangeli, A., Taglialatela, M., Morra, F., Castaldo, P., Crociani, O., Rosati, B., Faravelli, L., Olivotto, M. \& Wanke, E. Herg encodes a $\mathbf{K}^{+}$ current highly conserved in tumors of different histogenesis: a selective advantage for cancer cells? Cancer Res., 58, (4):815-822, 1998.

Bijlenga, P.; Occhiodoro, T.; Liu, J.; Bader, C.R.; Bernheim, L.; Fischer-Lougheed, J. An ether-a-go-go $\mathrm{K}^{+}$current, Ih_eag, contributes to the hyperpolarization of human fusion-competent myoblasts. J. Physiol. 512.2, pp. 317-323, 1998.

Blandino, J.K.; Viglione, M.P.; Bradley, W.A.; Oie, H.K.; Kim, Y.I. Voltage-dependent sodium channels in human small-lung cancer cells: role in action potentials and inhibition by Lambert-Eaton syndrome IgG. J. Memb. Biol., Jan; 143(2): 153-63, 1995.

Black, D.L. Mechanisms of alternative pre-messenger RNA splicing. Annu. Rev. Biochem. 72:291-336, 2003.

Blencowe, B.J. Alternative Splicing: New Insights from Global Analyses. Cell 126, Jul; 14, 2006. 
Brinkman, B.M. Splice variants as cancer biomarkers. Clin. Biochem. Jul; 37(7):584-94, 2004.

Brüggemann, A., Pardo, L.A., Stühmer, W. \& Pongs, O. Ether-à-go-go encodes a voltage-gated channel permeable to $\mathrm{K}^{+}$and $\mathrm{Ca}^{+2}$ and modulated by cAMP. Nature, 365, (6445): 445-448, 1993.

Brüggemann, A., Stühmer, W. \& Pardo, L.A. Mitosis-promoting factor-mediated supression of a cloned delayed rectifier potassium channel expressed in Xenopus oocytes. Proc. Natl. Acad. Sci. USA, 94, (2): 537-542, 1997.

Burge, C.B.; Padgett, R.A.; Sharp, P.A. Evolutionary fates and originsof U12-type introns. Molecular Cell, Vol. 2, 773-785, December, 1998.

Cabral, J.H.M., Lee, A., Cohen, S.L., Chait, B.T., Li, M. \& Mackinnon, R. Crystal structure and functional analysis of the HERG potassium channel $\mathbf{N}$ terminus: a eukariotic PAS domain. Cell, 95, (5): 649-655, 1998.

Camacho, J., Sánchez, A., Stühmer, W. \& Pardo, L.A. Cytoskeletal interactions determine the electrophysiological properties of human EAG potassium channel. Pflugers Arch., 441, (2-3): 167-174, 2000.

Chang, A.E.; Karnell, L.H.; Menck, H.R. The national caner data base report on cutaneous and noncutaneous melanoma. Cancer, October 15 . Vol. 83, n ${ }^{\circ}$, 1998.

Chandy, K.G., DeCoursay, T.E., Cahalan, M.D., McLaughlin, C. \& Gupta, S. Voltagegated potassium channels are required for human $T$ lymphocyte activation. J. Exp. Med., 160, (2): 369-385, 1984.

Chou, C.Y., Shen, M.R.; Wu, S.N. Volume-sensitive chloride channels associated with human cervical carcinogenesis. Cancer Res., 55, (24): 6077-6083, 1995.

Crociani, O., Cherubini, A., Piccini, E., Polvani, S., Costa, L., Fontana, L., Hofmann, G., Rosati, B., Wanke, E., Olivotto, M. \& Arcangeli, A. erg gene(s) expression during development of the nervous and muscular system of quail embryos. Mech. Dev., 95, (1-2): 239-243, 2000.

Cuddapah, V.A.; Sontheimer, H. Molecular interaction and functional regulation of CIC-3 by $\mathrm{Ca}^{+2} /$ calmodulin-dependent protein kinase II (CAMKII) in human malignant glioma. J.Biol. Chem. Feb 5, 2010.

DeCoursey, T.E.; Chandy, K.G.; Gupta, S.; Cahalan. M.D. Voltage-gated potassium channels in human $\mathbf{T}$ lypmphocytes: a role in mitogenesis? Nature, 307, (5950):465-468, 1984.

Desmond, R.A.; Soong, S. J. Epidemiology of malignant melanoma. Surg. Clin. North Am. Feb; 83(1):1-29, 2003. 
Dreixler, J.C., Bian, J., Cao, Y., Roberts, M.T., Roizen, J.D. \& Houamed, K.M. Block of rat brain recombinant $S K$ channels by tricycle antidepressants and related compounds. Eur. J. Pharmacol., 401, (1): 1-7, 2000.

Dworakowska, B.; Dołowy, K. Ion channels-related diseases. Acta Biochimica Polonica. Vol. 47, n³, 685-703, 2000.

Elbashir, S.M., Harborth, J., Lendeckel, W., Yalcin, A., Weber, K. \& Tuschl, T. Duplexes of 21-nucleotide RNAs mediate RNA interference in cultured mammalian cells. Nature, 411, (6836): 494-498, 2001.

Engeland, B., Neu, A., Ludwig, J., Roeper, J. \& Pongs, O. Cloning and functional expression of rat ether-à-go-go-like $\mathbf{K}^{+}$channel genes. J. Physiol., 513 (Pt 3), 647-654, 1998.

ElSharawy, A.; Manaster, C.; Teuber, M.; Rosenstiel, P.; Kwiatkowski, R.; Huse, K.; Platzer, M.; Becker, A.; Nürnberg, P.; Schreiber, S.; Hampe, J. SNPSplicer: systematic analysis of SNP-dependent splicing in genotyped cDNAs. Hum. Mutat. Nov; 27(11):1129-34, 2006.

Ernest, N.L.; Sontheimer, H. Extracellular glutamine is a critical modulator for regulatory volume increase in human glioma cells. Brain Research, 1144, 231-238, 2007.

Fairbrother, W.G.; Holste, D.; Burge, C.B.; Sharp, P.A. Single nucleotide polymorphism-based validation of exonic splicing enhancer. PLoS Biology. Vol.2, issue 9, September 2004.

Farias, L.M.B., Ocana, D.B., Díaz, L., Larrea, F., Avila-Chávez, E., Cadena, A., Hinojosa, L.M., Lara, G., Villanueva, L.A., Vargas, C., Hernández-Gallegos, E., Camacho-Arroyo, I., Duenas-González, A., Pérez-Cárdenas, E., Pardo, L.A., Morales, A., Taja-Chayeb, L., Escamilla, J., Sánchez-Pena, C. \& Camacho, J. Ether a go-go potassium channels as human cervical cancer markers. Cancer Res., 64, (19): 6996-7001, 2004.

Fire, A., Xu, S., Montgomery, M.K., Kostas, S.A., Driver, S.E. \& Mello, C.C. Potent and specific genetic interference by double-stranded RNA in Caenorhabditis elegans. Nature, 391, (6669): 806-811, 1998.

Fiske, J.L.; Fomin, V.P.; Brown, M.L.; Duncan, R.L.; Sikes, R.A. Voltage-sensitive ion channels and cancer. Cancer Metastasis Rev. Sep; 25(3):493-500, 2006.

Förch, P.; Valcárcel, J. Splicing regulation in Drosophila sex determination. Prog. Mol. Subcell. Biol. 31:127-51, 2003.

Fraser, S.P., Grimes J.A., D. M. Effects of voltage-gated ion channel modulators on rat prostatic cancer cell proliferation: comparison of strongly and weakly metastatic cell lines. Prostate, 44 (1), 61-76, 2000. 
García-Ferreiro, R.E., Kerschensteiner, D., Major, F., Monje, F., Stühmer, W. \& Pardo, L. A. Mechanim of block of hEag1 $\mathrm{K}^{+}$channels by imipramine and astemizole. J. Gen. Physiol., 124, (4): 301-317, 2004.

Gessner, G.; Zacharias, M.; Bechstedt, S.; Schönherr, R.; Heinemann, S.H. Molecular determinants for high-affinity block of human EAG potassium channels by antiarrhythmic agents. Mol. Pharmacol. 65(5):1120-29, 2004.

Grimes, J.A.; Fraser, S.P.; Stephens, G.J.; Downing, J.E.; Laniado, M.E.; Foster, C.S.; Abel, P.D.; Djamgoz, M.B. Differential expression of voltage-activated $\mathrm{Na}^{+}$ currents in two prostatic tumour cell lines: contribution to invasiveness in vitro. FEBS Lett, 369, (2-3):290-294, 1995.

García-Blanco, M.A.; Baraniak, A.P.; Lasda, E.L. Alternative splicing in disease and therapy. Nat. Biotechnol. May; 22(5):535-46, 2004.

Gavrilova-Ruch, O.; Schönherr, K.; Gessner, G.; Schönherr, R.; Klapperstück, T.; Wolrab, W.; Heinemann, S.H.; Effects of imipramine on ion channels and proliferation of IGR1 melanoma cells. J. Membrane Biol. 188, 137-149, 2002.

Grabowski, P.J.; Black, D.L. Alternative RNA splicing in the nervous system. Prog. Neurobiol. Oct; 65(3):289-308, 2001.

Gray, L.S.; MacDonal, T.L. The pharmacology and regulation of $\mathbf{T}$ type calcium channels: new opportunities for unique therapeutics for cancer. Call Calcium. Aug; 40(2):115-20, 2006.

Haccard, O.; Jessus, C. Redundant pathways for Cdc2 activation in Xenopus oocyte: either cyclin B or Mos synthesis. EMBO reports vol.7, n³, 2006.

Hastings, K.E. SL trans-splicing: easy come or easy go? Trends Genet. Apr; 21(4):240-7, 2005.

Heider, K.H.; Kuthan, H.; Stehle, G.; Munzert, G. CD44v6: a target for antobodybased cancer therapy. Cancer Immunol. Immunother. Jul; 53(7):567-79, 2004.

Hemmerlein, B.; Weseloh, R.M.; Mello de Queiroz, F.; Knötgen, H.; Sánchez, A.; Rubio, M.E.; Martin, S.; Schliephacke, T.; Jenke, M.; Radzun, H.J.; Stühmer, W.; Pardo, L.A. Overexpression of Eag1 potassium channels in clinical tumours. Molecular Cancer. 5:41, 2006.

Herrlich, P.; Morrison, H.; Sleeman, J.; Orian-Rousseau, V.; König, H.; Weg-Remers, $\mathrm{S}$.; Ponta, $\mathrm{H}$. CD44 acts both as growth- and invasiveness-promoting molecule and as a tumor suppressing cofactor. Ann. N. Y. Acad. Sci. Jun; 910:106-18; discussion 118-20, 2000. 
Hoang, B.X.; Levine, S.A.; Pham, P.; Shaw, D.G. Hypothesis of the cause and development of neoplasms. Eur. J. Cancer Prev. Feb; 16(1):55-61, 2007.

Jemal, A.; Siegel, R.; Ward, E.; Murray, T.; Xu, J.; Smigal, C.; Thun, M.J. Cancer statistics, 2006. CA Cancer J. Clin. Mar-Apr; 56(2):106-30, 2006.

Jenke, M.; Sanchez, A.; Monje, F.; Stühmer, W.; Weseloh, R.M.; Pardo, L.A. Cterminal domains implicated in the functional surface expression of potassium channels. The EMBO Journal Vol. 22, n³, 395-403, 2003.

Jiang, Y.; Lee, A.; Chen, J.; Ruta, V.; Cadene, M.; Chait, B.T.; MacKinnon, R. X-ray structure of a voltage-dependent $\mathbf{K}^{+}$channel. Nature, 423, (6935):33-41, 2003a.

Jiang, Y.; Ruta, V.; Chen, J.; Lee, A.; MacKinnon, R. The principle of gating charge movement in a voltage-dependent $\mathbf{K}^{+}$channel. Nature, May 1; 423(6935):42$8,2003 b$.

Ju, M.; Wray, D. Molecular identification and characterization of the human eag2 potassium channel. FEBS Letters 524, 204-210, 2002.

Kabbarah, O.; Chin, L. Revealing the genomic heterogeneity of melanoma. Cancer Cell: 439-441, December 2005.

Kalnina, Z.; Zayakin, P.; Silina, K.; Line, A. Alterations of pré-mRNA splicing in cancer. Genes Chromosomes Cancer Apr; 42(4):342-57, 2005.

Kampa, D.; Cheng, J.; Kapranov, P.; Yamanaka, M.; Brubaker, S.; Cawley, S.; Drenkow, J.; Piccolboni, A.; Bekiranov, S.; Helt, G.; Tammana, H.; Gingeras, T. Novel RNAs identified from an in-depth analysis of the transcriptome of human chromosomes 21 and 22. Genome Res. 14: 331-342, 2004.

Kaplan, W.D.; Trout, W.E. The behaviour of four neurological mutants of Drosophila. Genetics, 61, (2): 399-409, 1969.

Köhler, R.; Degenhardt, C.; Kühn, M.; Runkel, N.; Paul, M.; Hoyer, J. Expression and function of endothelial $\mathrm{Ca}^{+2}$-activated $\mathrm{K}^{+}$channels in human mesenteric artery: a single-cell reverse transcriptase-polymerase chain reaction and electrophysiological study in situ. Circ. Res. 87, (6): 496-503, 2000.

Kohn, E.C.; Reed, E.; Sarosy, G.; Christian, M.; Link, C.J.; Cole, K.; Figg, W.D.; Davis, P.A.; Jacob, J.; Goldspiel, B.; Liotta, L.A. Clinical investigation of a cytostatic calcium influx inhibitor in patients with refractory cancers. Cancer Res., 56, (3): 569-573, 1996. 
Kunzelmann, K. Ion channels and cancer. J. Membrane Biol. 205, 159-173, 2005.

Lambert, P.A.; Somers, K.D.; Kohn, E.C.; Perry, R.R. Antiproliferative and antiinvasive effects of carboxyamido-triazole on breast cancer cell lines. Surgery, 122, (2): 372-8; discussion 378-9, 1997.

Laniado, M.E.; Fraser, S.P.; Djamgoz, M.B. Voltage-gated $\mathbf{K}^{+}$channel activity in human prostate cancer cell lines of markedly different metastatic potential: distinguishing characteristics of PC-3 and LNCaP cells. Prostate, 46, (4): 262-274, 2001.

Lemischka, I.R.; Pritsker, M. Alternative splicing increases complexity of stem cell transcriptome. Cell cycle 5:4, 347-351, 2006.

Levitan, I.; Garber, S.S. Voltage-dependent inactivation of volume-regulated $\mathrm{Cl}^{-}$ current in human T84 colonic and B-cell myeloma cell lines. Pflugers Arch, 431, (2):297-299, 1995.

Lewis, R.S.; Cahalan, M.D. Potassium and calcium channels in lymphocytes. Annu. Rev. Immunol. 13:623-53, 1995.

Lewis, A.S.; Schwartz, E.; Savio Chan, C.; Noam, Y.; Shin, M.; Wadman, W.J.; Surmeier, D.J.; Baram, T.Z.; Macdonald, R.L.; Chetkovich, D.M. Alternatively spliced isoforms of TRIP8b differentially control $h$ channel trafficking and function. J. Neurosci. May 13; 29(19): 6250-6265, 2009.

Lopez, A.J. Alternative splicing of pre-mRNA: developmental consequences and mechanisms of regulation. Annu. Rev. Genet. 32:279-305, 1998.

Lörinczi, E.; Napp, J.; Contreras-Jurado, C.; Pardo, L.A.; Stühmer, W. The voltage dependence of hEag currents is not determined solely by membranespanning domains. Eur. Biophys. J, 2008.

Ludwig, J.; Terlau, H.; Wunder, F.; Brüggemann, A.; Pardo, L.A.; Marquardt, A.; Stühmer, W.; Pongs, O. Functional expression of a rat homologue of the voltage gated ether a go-go potassium channel reveals differences in selectivity and activation kinetics between the Drosophila channel and its mammalian conterpart. The EMBO Journal vol. 13, n¹9, 4451-4458, 1994.

Malhi, H., Irani, A.N.; Rajvanshi, P.; Suadicani, S.O.; Spray, D.C.; Mcdonald, T.V.; Gupta, S. KATP channels regulate mitogenically induced proliferation in primary rat hepatocytes and human liver cell lines. Implications for liver growth control and potential therapeutic targeting. J. Biol. Chem. 275, (34): 26050-26057, 2000.

Mamelak, A.N.; Rosenfeld, S.; Bucholz, R.; Raubitschek, A.; Nabors, L.B.; Fiveash, J.B.; Shen, S.; Khazaeli, M.B.; Colcher, D.; Liu, A.; Osman, M.; Guthrie, B.; 
Schade-Bijur, S.; Hablitz, D.M.; Alvarez, V.L.; Gonda, M.A. Phase I singledose study of intracavitary-administered iodine-131-TM-601 in adults with recurrent high-grade glioma. J. Clin. Oncol. Aug 1; 24(22): 3644-50, 2006.

Maniatis, T.; Tasic, B. Alternative pre-mRNA splicing and proteome expansion in metazoans. Nature Jul 11; 418(6894): 236-43, 2002.

Marino, A.A.; Iliev, I.G.; Schwalke, M.A.; Gonzalez, E.; Marler, K.C.; Flanagan, C.A. Association between cell membrane potential and breast cancer. Tumor Biol. 15:82-89, 1994.

Matfen, W.; Daar, I.; Vande Woudel, G. F. Protein kinase a acts at multiple points to inhibit xenopus oocyte maturation. Mol. Cell. Biol. Vol. 14, No. 7 July, 44194426, 1994.

Mauro, T.; Dixon, D.B.; Komuves, L.; Hanley, K.; Pappone, P.A. Keratinocyte $\mathbf{K}^{+}$ channels mediate $\mathbf{C a}^{+2}$ induced differentiation. J. Invest. Dermatol. 108, (6): 864-870, 1997.

Mello de Queiroz, F.; Suarez-Kurtz, G.; Stühmer, W.; Pardo, L.A. Ether à go-go potassium channel expression in soft tissue sarcoma patients. Molecular Cancer, 5:42, 2006.

Meyer, R.; Heinemann, S.H. Characterization of an eag-like potassium channel in human neuroblastoma cells. J. Physiol. 508 (Pt 1), 49-56, 1998.

Meyer, R.; Schönherr, R.; Gavrilova-Ruch, O.; Wohlrab, W.; Heinemann, S.H. Identification of ether à go-go and calcium-activated potassium channels in human melanoma cells. J. Membr. Biol. 171, (2): 107-115, 1999.

Narla, G.; DiFeo, A.; Reeves, H.; Schaid, D.; Hirshfeld, J.; Hod, E.; Katz, A.; Isaacs, W.; Hebbring, S.; Komiya, A.; McDonnell, S.; Wiley, K.; Jacobsen, S.; Isaacs, S.; Walsh, P.; Zheng, S. L.; Chang, B.; Friedrichsen, D.; Stanford, J.; Ostrander, E.; Chinnaiyan, A.; Rubin, M.; Xu, J.; Thibodeau, S.; Friedman, S.; Martignetti, J.A. A Germline DNA Polymorphism Enhances Alternative Splicing of the KLF6 Tumor Suppressor Gene and Is Associated with Increased Prostate Cancer Risk. Cancer Res 2005; 65: (4). February 15, 2005 a.

Narla, G.; DiFeo, A.; Yao, S.; Banno, A.; Hod, E.; Reeves, H. L.; Qiao, R. F.; CamachoVanegas, O.; Levine, A.; Kirschenbaum, A.; Chan, A.; Friedman, S.; Martignetti, J. A. Targeted inhibition of the klf6 splice variant, klf6 sv1, suppresses prostate cancer cell growth and spread. Cancer Res 2005; 65: (13). July 1, 2005b.

Nature Cell Biology Whither Rnai? Vol.5, nº ${ }^{\circ}$, June 2003.

Nilius, B.; Wohlrab, W. Potassium Channels And Regulation Of Proliferation Of Human Melanoma Cells. Journal of Physiology 445, pp. 537-548, 1992. 
Occhiodoro, T.; Bernheim, L.; Liu, J.H.; Bijlenga, P.; Sinnreich, M.; Bader, C.R.; Fischer-Lougheed, J. Cloning of a human ether à-go-go potassium channel expressed in myoblasts at the onset of fusion. FEBS Lett., 434, (1-2): 177$182,1998$.

Orban, T.I.; Olah, E. Emerging roles of BRCA1 alternative splicing. J Clin Pathol: Mol Pathol;56:191-197, 2003.

Pfaffl, M.; A new mathematical model for relative quantification in real-time RTPCR. Nucleic Acids Research, vol.29, n9, 2001.

Pfaffl, M.; Horgan, G.W.; Dempfle, L. Relative expression software tool (RESTC) for group-wise comparison and statistical analysis of relative expression results in real-time PCR. Nucleic Acids Research, vol.30, n 92002.

Pajares, M.J.; Ezponda, T.; Catena, R.; Calvo, A.; Pio, R.; Montuenga, L.M. Alternative splicing: an emerging topic in molecular and clinical oncology. Lancet Oncol; 8: 349-57, 2007.

Pardo, L.A.; Brüggemann, A.; Camacho, J.; Stühmer, W. Cell cycle-related changes in the conducting properties of r-eag $\mathbf{K}^{+}$channels. J. Cell Biol. 143, (3): 767$775,1998$.

Pardo, L.A.; del Camino, D.; Sáchez, A.; Alves, F.; Brüggemann, A.; Beckh, S.; Stühmer, W. Oncogenic potential of Eag $\mathbf{K}^{+}$channels. The EMBO Journal vol.18, $\mathrm{n}^{\circ} 20,5540-5547,1999$.

Philpott, A.; Yew, P.R. The Xenopus cell cycle: an overview. Mol. Biotechnol. May; 39(1): 9-19, 2008.

Pritsker, M.; Doniger, T.T.; Kramer, L.C.; Westcot, S.E.; Lemischka, I.R. Diversification of stem cell molecular repertoire by alternative splicing. PNAS, vol. 102, no. 40, October 4, 2005.

Pritsker, M.; Ford, N.R.; Jenq, H.T.; Lemischka, I.R. Genomewide gain-of-function genetic screen identifies functionally active genes in mouse embryonic stem cells. PNAS, vol. 103, no. 18, May 2, 2006.

Rane, S.G. The growth regulatory fibroblast IK channel is the prominent electrophysiological feature of rat prostatic cancer cells. Biochem. Biophys. Res. Commun, 269, (2): 457-463, 2000.

Rangaraju, S.; Chi, V.; Pennington, M.W.; Chandy, K.G. Kv1.3 potassium channels as a therapeutic target in multiple sclerosis. Expert Opin. Ther. Targets Aug; 13(8): 909-24, 2009.

Ranson, C.B.; O’Neal, J.T.; Sontheimer, H. Volume-activated chloride currents 
contribute to the resting conductance and invasive migration of human glioma cells. J. Neurosci., Oct.1; 21(19): 7674-7683, 2001.

Rigel, D.S.; Carucci, J.A. Malignant Melanoma: Prevention, Early Detection, and Treatment in the 21st Century. CA Cancer J. Clin. 50: 215-236, 2000.

Riven, I.; Kalmanzon, E.; Segev, L.; Reuveny, E. Conformational Rearrangements Associated with the Gating of the $\mathbf{G}$ Protein-Coupled Potassium Channel Revealed by FRET Microscopy. Neuron, vol. 38, 225-235, April 24, 2003.

Rizk, S.N.; Ryan, J.J. Current concepts review: management of melanoma. S. D. J. Med. Jul; 47(7): 217-21, 1994.

Robertson, G.A.; Warmke, J.W.; Ganetzky, B. Potassium Currents Expressed from Drosophila and Mouse eag cDNAs in Xenopus Oocytes. NeuropharmacologyVol. 35, No. 7, pp. 841-850, 1996.

Roger, S.; Potier, M.; Vandier, C.; Besson, P.; Le Guennec, J.Y. Voltage-gated sodium channels: new target in cancer therapy? Curr. Pharm. Des. 12(28): 3681-95, 2006.

Rouzaire-Dubois, B.; Milandri, J.B.; Bostel, S.; Dubois, J.M. Controlo f cell proliferation by cell volume alterations in rat $\mathbf{C 6}$ glioma cells. Pflugers Arch, 440, (6): 881-888, 2000.

Saganich, M.J.; de Miera, E.V.S.; Nadal, M.S.; Baker, H.; Coetzee, W.; Rudy, B.; Cloning of components of a novel subthreshold-activating $\mathrm{K}^{+}$channel with a unique pattern of expression in the cerebral cortex. J. Neurosci, 19, (24): 10789-10802, 1999.

Saganich, M.J.; Machado, E.; Rudy, B. Differential expression of genes encoding subthreshold-operating voltage-gated $\mathbf{K}^{+}$channels in brain. J. Neurosci. 21, (13): 4609-4624, 2001.

Sato, K.; Ishizuka, J.; Cooper, C.W.; Chung, D.H.; Tsuchiya, T.; Uchida, T.; Rajaraman, S.; Townsend, C.M.; Thompson, J.C.; Inhibitory effect of calcium channel blockers on growth of pancreatic cancer cells. Pancreas, 9, (2): 193-202, 1994.

Schönherr, R.; Löber, K.; Heinemann, S.H. Inhibition of human ether à go-go potassium channel by $\mathbf{C a}^{+2} /$ calmodulin. The EMBO Journal Vol.19, $\mathrm{n}^{\circ} 13,3263$ 3271, 2000.

Schönherr, R.; Mannuzzu, L.M.; Isacoff, E.Y.; Heinemann, S.H. Conformational switch between slow and fast gating modes: allosteric regulation of voltage sensor mobility in the EAG K $\mathbf{K}^{+}$channel. Neuron, vol. 35, 935-949, 2002.

Schönherr, R. Clinical relevance of ion channels for diagnosis and therapy of 
cancer. J. Membr. Biol. Jun; 205(3): 175-84, 2005.

Shi, W.; Wymore, R.S.; Wang, H.; Pan, Z.; Cohen, I.S.; McKinnon, D.; Dixon, J.E. Identification of two nervous system-specific members of the erg potassium channel gene family. J. Neurosci., December 15,17(24):9423-9432, 1997.

Shi, W.; Wang, H.S.; Pan, Z.; Wymore, R.S.; Cohen, I.S.; McKinnon, D.; Dixon, J.E. Cloning of a mammalian elk potassium channel gene and EAG mRNA distribution in rat sympathetic ganglia. J. Physiol. Sep 15; 511 (Pt 3): 675-82, 1998.

Silverman, W.R.; Tang, C.; Mock, A. F.; Huh, K.; Papazian, D.M. Mg ${ }^{+2}$ modulates voltage-dependent activation in ether-à-go-go potassium channels by binding between transmembrane segments S2 and S3. J. Gen. Physiol Vol.116, 663-677, November 2000.

Skotheim, R.I.; Nees, M. Alternative splicing in cancer: Noise, functional, or systematic? The International Journal of Biochemistry \& Cell Biology 39: 1432-1449, 2007.

Skryma, R.N.; Prevarskaya, N.B.; Dufy-Barbe, L.; Odessa, M.F.; Audin, J.; Dufy, B. Potassium conductance in the androgen-sensitive prostate cancer cell line, LNCaP: involvement in cell proliferation. Prostate, 33, (2):112-122, 1997.

Smith, L. D. The induction of oocyte maturation: transmembrane signaling events and regulation of the cell cycle. Development 107, 685-699, 1989.

Solomon, M.J. Activation of the various cyclin/cdc2 protein kinases. Curr. Opin. Cell Biol. Apr; 5(2): 180-6, 1993.

Sontheimer, H. An unexpected role for ion channels in brain tumor metastasis. Exp. Biol. Med. (Maywood). July; 233(7): 779-791, 2008.

Stamm, S.; Riethoven, J.; Le Texier, V.; Gopalakrishnan, C.; Kumanduri, V.; Tang, Y.; Barbosa-Morais, N.L.; Thanaraj, T.A. ASD: a bioinformatics resource on alternative Splicing. Nucleic Acids Research, vol. 34, 2006.

Stevens, L.; Ju, M.; Wray, D. Roles of surface residues of intracellular domains of heag potassium channels. Eur. Biophys. J. 38:523-532, 2009.

Stansfeld, C.E.; Roper, J.; Ludwig, J.; Weseloh, R.M.; Marsht, S.J.; Brownt, D.A.; Pongs, O. Elevation of intracellular calcium by muscarinic receptor activation induces a block of voltage-activated rat ether-a-go-go channels in a stably transfected cell line. Proc. Natl. Acad. Sci. USAVol. 93, pp. 99109914, September 1996.

Stühmer, W.; Alves, F.; Hartung, F.; Zientkowska, M.; Pardo, L.A. Potassium channels as tumour markers. FEBS Lett. May 22; 580(12): 2850-2, 2006. 
Suessbrich, H.; Waldegger, S.; Lang, F.; Busch, A.E. Blockade of HERG channels expressed in Xenopus oocytes by the histamine receptor antagonists terfenadine and astemizole. FEBS Letters 385:7 7-80, 1996.

Sumanasekera, C.; Watt, D.S.; Stamm, S. Substances that can change alternative splice-site selection. Biochem. Soc. Trans. 36, 483-490; 2008.

Sun, X.X.; Bostrom, S. L.; Griffith, L.C. Alternative splicing of the eag potassium channel gene in Drosophila generates a novel signal transduction scaffolding Protein. Mol. Cell. Neurosci. March; 40(3): 338-343, 2009.

Tang, C.; Bezanilla, F.; Papazian, D.M. Extracellular $\mathbf{M g}^{+2}$ modulates slow gating transitions and the opening of Drosophila ether-à-go-go potassium channels. J. Gen. Physiol. vol.115, 319-337, March 2000.

Terlau, H.; Ludwig, J.; Steffan, R.; Pongs, O.; Stühmer, W.; Heinemann, S.H. Extracellular Mg2+ regulates activation of rat eag potassium channel. Pßügers Arch - Eur J Physiol. 432: 301-312, 1996.

Thompson, J.F.; Scolyer, R.A.; Kefford, R.F. Cutaneous melanoma. Lancet Feb. 1925; 365(9460): 687-701, 2005.

Ugurel, S.; Utikal, J.; Becker, J.C. Tumor Biomarkers in Melanoma. Cancer Control vol. 16, no. 3, July 2009.

Ulrich, N.; Gillespie, G.Y.; Sontheimer, H. Human astrocytoma cell express a unique chloride current. Neuroreport, 7, (5): 1020-1024, 1996.

Veiseh, O.; Gunn, J.W.; Kievit, F.; Sun, C.; Fang, C.; Lee, J.S.H.; Zhang, M. Inhibition of Tumor Cell Invasion with Chlorotoxin-Bound Superparamagnetic Nanoparticles. Small, Feb; 5(2): 256-264, 2009.

Venables, J.P. Alternative splicing in the testes. Curr. Opin. Genet. Dev. Oct;12(5):615-19, 2002.

Venables, J.P. Aberrant and Alternative Splicing in Cancer. Cancer Research 64, 7647-7654, November 1, 2004.

Venables, J.P. Unbalanced alternative splicing and its significance in cancer. Bioessays. Apr; 28(4):378-86, 2006.

Venables, J.P.; Burn, J. EASI-enrichment of alternatively spliced isoforms. Nucleic Acids Research, vol. 34, no. 15, 2006.

Villalonga, N.; Ferreres, J.C.; Argilés, J.M.; Condon, E.; Felipe, A. Potassium channels are a new target Field in anticancer drug design. Recent Pat Anticancer Drug Discov. Nov; 2(3):212-23, 2007. 
Wang, F.; Zhao, Y.; Ha, Y.; Tan, Z. Identification of low-abundance alternatively spliced mRNA variants by exon exclusive reverse transcriptase polymerase chain reaction. Analytical Biochemistry 383: 307-310, 2008.

Wang, G.; Lemos, J.R.; Iadecola, C. Herbal alkaloid tatrandrine: from na ion channel blocker to inhibitor of tumor proliferation. Trends Pharmacol. Sci. Mar; 25(3): 120-3, 2004.

Wang, Z. Roles of $\mathbf{K}+$ channels in regulating tumour cell proliferation and apoptosis. Pflugers Arch - Eur J Physiol 448: 274-286, 2004.

Warmke, J.; Drysdale, R.; Ganetzkyt, B. A Distinct Potassium Channel Polypeptide Encoded by the Drosophila eag Locus. Science, Vol. 252, 1991.

Warmke, J.W.; Ganetzky, B. A family of potassium channel genes related to eag in Drophila and mammals. Proc. Natl. Acad. Sci. USA Vol. 91, pp. 3438-3442, April 1994.

Wasilenko, W.J.; Palad, A.J.; Somers, K.D.; Blackmore, P.F.; Kohn, E.C.; Rhim, J.S.; Wright, G.L.; Schellhammer, P.F. Effects of the calcium influx inhibitor carboxyamido-triazole on the proliferation and invasiveness of human prostate tumor cell lines. Int. J. Cancer, 8, (2): 259-264, 1996.

Watson, P.A. Function follows form: generation of intracellular signals by cell deformation. The FASEB Journal Vol. 5 April 1991.

Weiss, H.; Brinton, L.A.; Potischman, N.A.; Brogan, D.; Coates, R..; Gammon, M.D.; Malone, K.E.; Schoenberg, J.B. Breast cancer risk in young women and history of selected medical conditions. Internal Journal of Epidemiology 28: 816$823,1999$.

Wonderlin, W.F.; Strobl, J.S. Potassium channels, proliferation and G1 progression. J. Membr. Biol. Nov; 154 (2): 91-107, 1996.

Woodfork, K.A.; Wonderlin, W.F.; Peterson, V.A.; Strobl, J.S. Inhibition of ATPsensitive potassium channels causes reversible cell-cycle arrest of human breast cancer cells in tissue culture. J. Cell Physiol., 162, (2): 163-171, 1995.

Wray, D. The roles of intracellular regions in the activation of voltage-dependent potassium channels. Eur. Biophys. J. 33: 194-200, 2004.

Wray, D. Intracellular regions of potassium channels: Kv2.1 and heag. Eur. Biophys. J. 38:285-292, 2009.

Wu, J.; Haugk, K.; Plymate, S. R. Activation of Pro-apoptotic p38-MAPK Pathway in the Prostate Cancer Cell Line M12 Expressing a Truncated IGF-IR. Horm Metab Res. 35: 751-757, 2003. 
Yamamura, H.; Ugawa, S.; Ueda, T.; Morita, A.; Shimada, S. TRPM8 activation suppresses cellular viability in human melanoma. Am J Physiol Cell Physiol 295: C296-C301, 2008. 